University of Louisville

ThinkIR: The University of Louisville's Institutional Repository

Electronic Theses and Dissertations

1939

\title{
Factors affecting the bronzing of Prussian blue pigments.
}

Nathan William Muller

University of Louisville

Follow this and additional works at: https://ir.library.louisville.edu/etd

Part of the Chemical Engineering Commons

\section{Recommended Citation}

Muller, Nathan William, "Factors affecting the bronzing of Prussian blue pigments." (1939). Electronic Theses and Dissertations. Paper 1862.

https://doi.org/10.18297/etd/1862

This Master's Thesis is brought to you for free and open access by ThinkIR: The University of Louisville's Institutional Repository. It has been accepted for inclusion in Electronic Theses and Dissertations by an authorized administrator of ThinkIR: The University of Louisville's Institutional Repository. This title appears here courtesy of the author, who has retained all other copyrights. For more information, please contact thinkir@louisville.edu. 


\title{
UAIVRASTIT OF LOUTSVILL
}

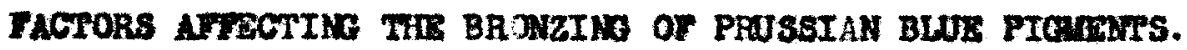

\author{
A Desertation \\ Sulditted to the ramity \\ Of the Graente Sohoel of the Untroralty of Louleville \\ In Partiel hulf1lmout of the \\ Regairmante for the Degree of
}

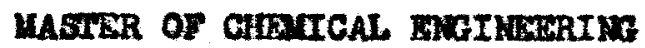

Dopartent of Chenteal Fuginoering

by

latban Tllian Naller

1939 


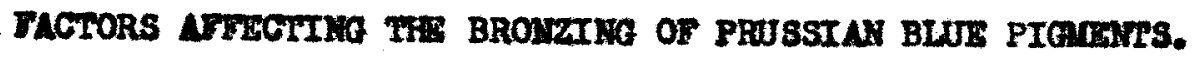

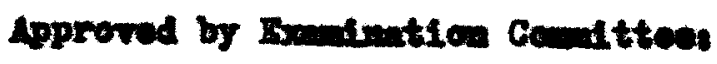

Arotex:

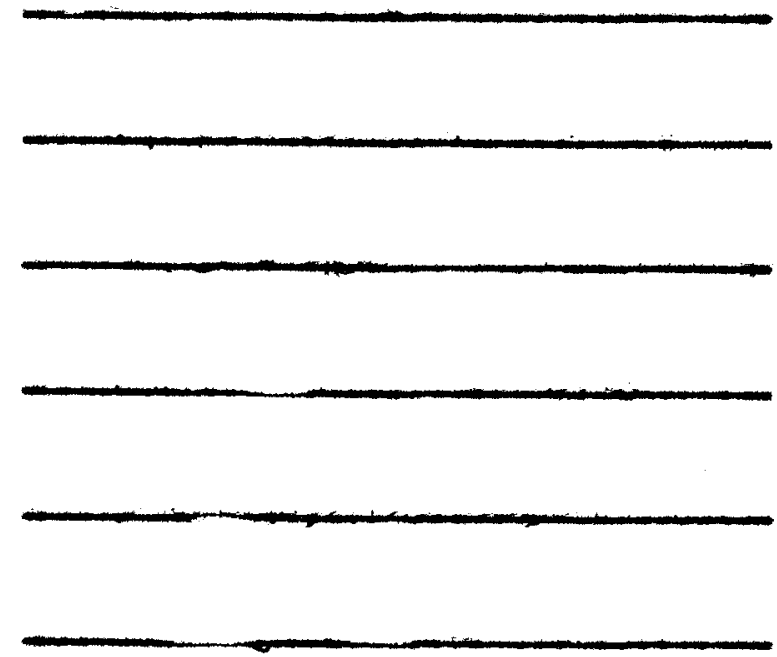

Approved for lioks

Juan 6,1939 
TABLE of commits

Let of Table

Lit of Fenro

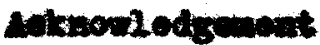

Introduction

IIt torteal

Wheortieal

Eperimantal

Date and Roalte

Decanetion of Rowute

samy

Conoludion:

Btwlecanples
Page

4

It

1

3

7

16

2

57

75

79

81 
Table

Page

$\mathbf{I}$

Efrot of Texperature

Variation

24

$\mathbf{I}$

Verietion of macion

alphate Coutent in

Fonniation

27

III Effoct of Addition of

orgente atwe in Place

of Amentiv sulphato

30

IV Befeot of abotitution of Inorgunte salte for umantim Sulpate

7 Hothod of Iddition of oxtdisting Agont

II Iffeot of comountration of Oxtalding Apon

II Hereet of Varlowe Odeldins Aranto

III zffeet of Consentration of sodiu Forroogratide and

Parreue enlphate

4

Ix

Soquaneo of Mddition of Roactance for the rorwation of the Intormodite Paste

I refoot of pll on Oxication and Parte Ponnitson 
LIST or TABLEs ( contined)

Table

Page

II

Effeot of Addition of Bodiun Grandid to the

Torroojande

III

afreat of Malition or Sodtu Forrtemanide to the Borrogrante

III Effect of Dryins on the Broustive of the Blap

II Bfics of Partide size on Bronse and Tinting otrungth

$\boldsymbol{x}$

Refect: of Thamoagulos on the Broute and Itintirs Strungth ac a Plgavit

$\mathbf{x n}$

Compounde Proenat Darin. the Forictien of Prapolin BIne

7 
LIsT or Fravats

Hewre

Page

1. Path of Inoldont hist

Thron a Plonentod Tla

25

2. Rffect of Temperature of

Oxdation on Brense

25

3. Imond Contont in Inal

Plgient

26

4. Replacoment of buponitum

alphate by Organte stives 31

5. Roplacwoint of trogulu

sulphate by Inorgate salte 34

6. Frfeet of Partiele sixe on

Brance

50

7. Ifreet of Plgwat Vehtale an

Broune

8. Zifret of Gonthe the Dr FII wh clear vomat

9.

Plgnowed Laequer MIn

56 
$T$

Author Winkos

to Aoknowleds ite

Approaletion

for 411 the Kad and Veluable At

arrea by D. O. C. Militen,

Who DLroted into Researdh 
Inreapecrion 


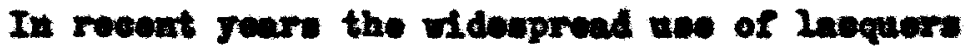
In the artemotive Indutisy areated a denand for a trpe of

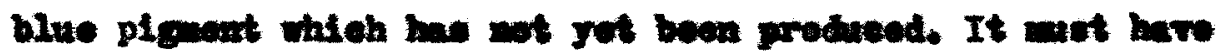
all of the propertien of the pribtore' blue exeopt one 1.0.

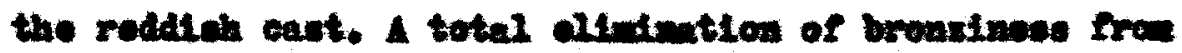

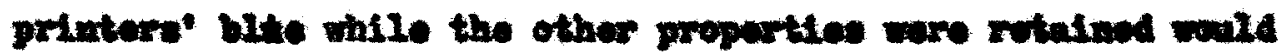

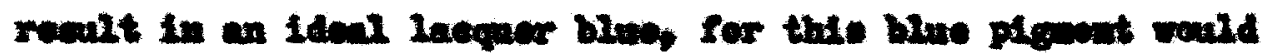
the hare the follening jroportleat

1. berutum of ealery

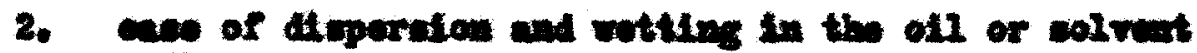
moturn.

8. a wat thitus ctrangh.

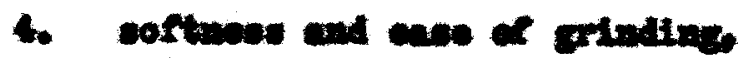

5. Who teg-tewe and overteme athot ar trace of bromes or rod aut by ather rancoted or trmented 14int.

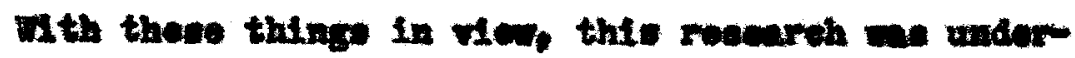

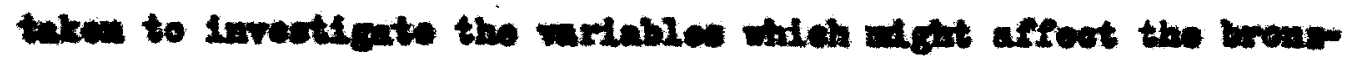
Lits tadiong of the plemat. 
HTXXRTCAT. 


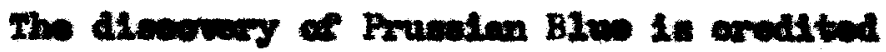

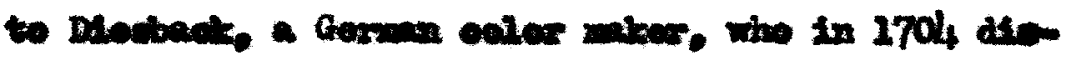

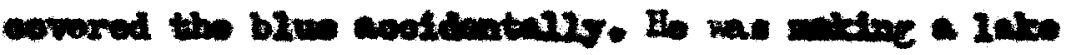

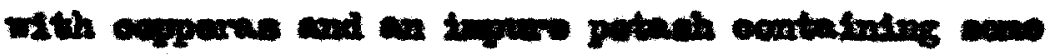

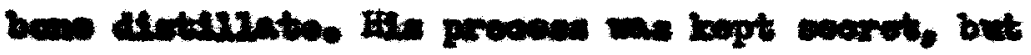

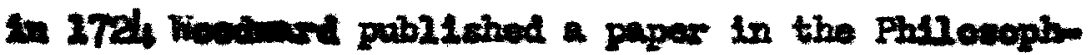

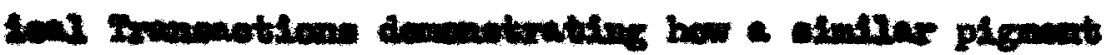

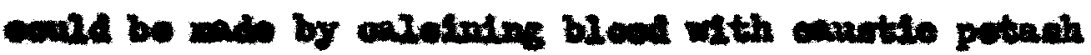

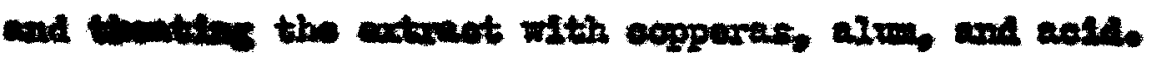

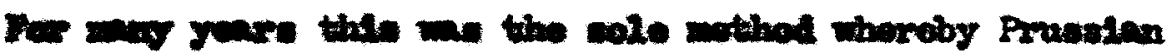
D2n me produced.

AImot a hundrod years pasond before any

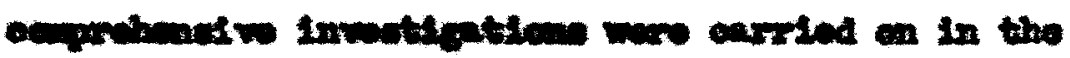

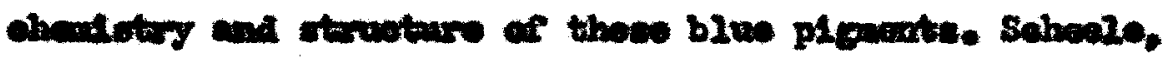

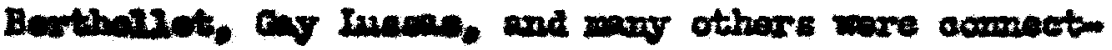

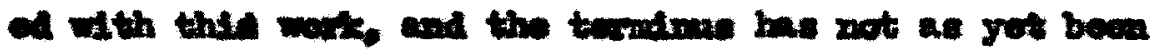
reaminat.

Comeredex expledtation of the pigment was

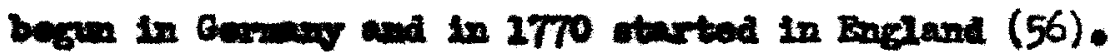

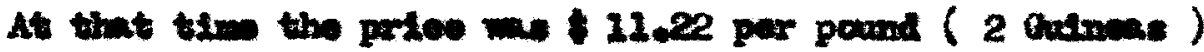
jot expaty yeare later the pries bes been grodually

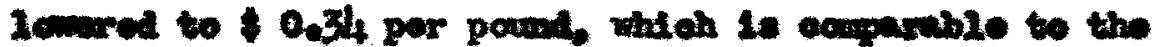

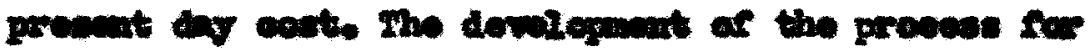




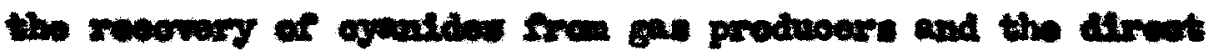

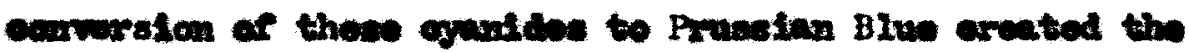
promeat ang price levis.

At the outset of the World Wax in 2944 tho

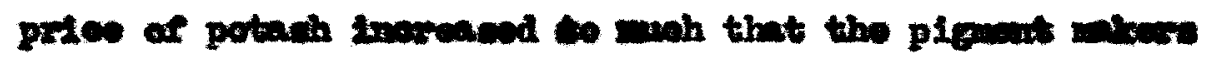

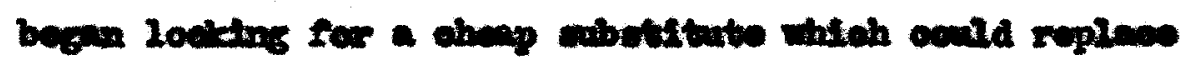

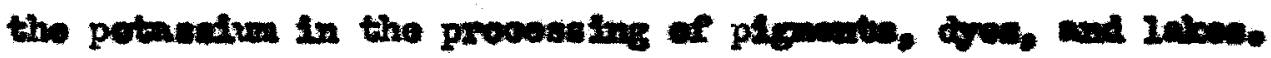

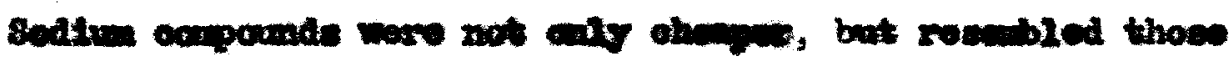

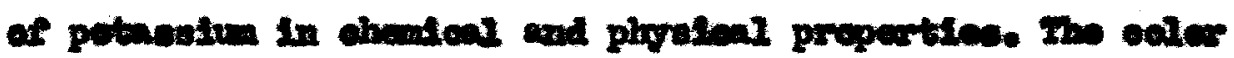

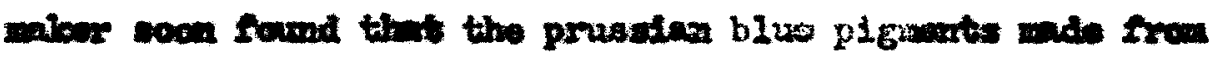

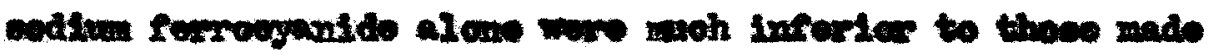
Iren the potesestem wit (56). It was found that a part of the

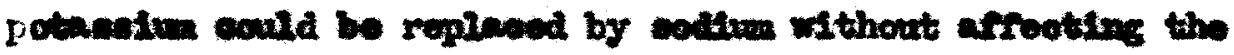

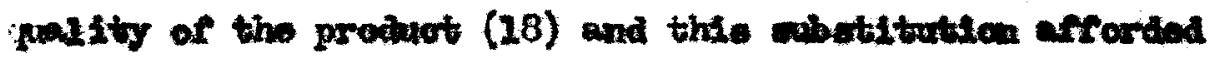

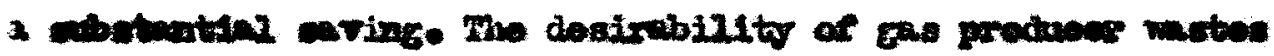

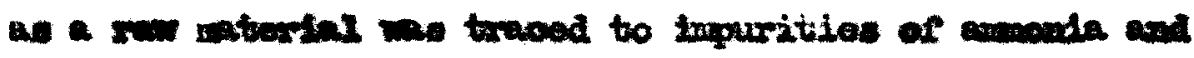

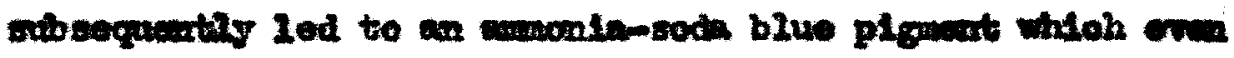
aryanad the orfiginal potasin bInen. At the prosent time ous rory anll guantitios of potach blus are made, and thowe aro for apecial purpomen rather then for goneral une.

As the invertigation of the ohoudical and phunteal properties progrened, so did the production of variatican

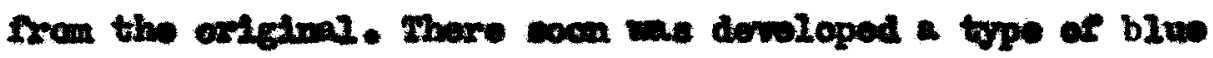




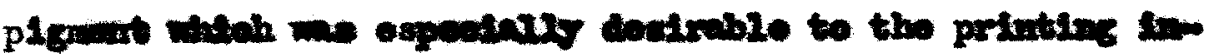

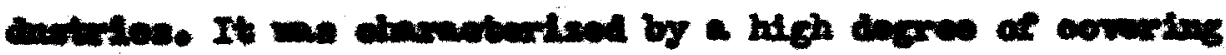

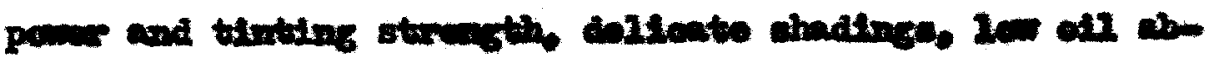

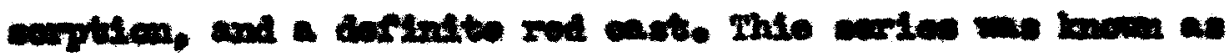

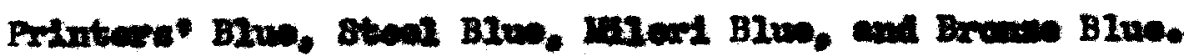

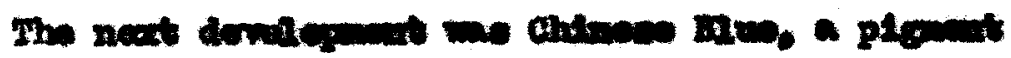

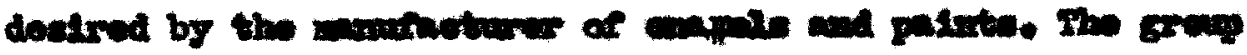

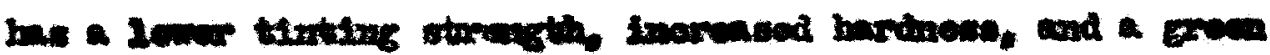

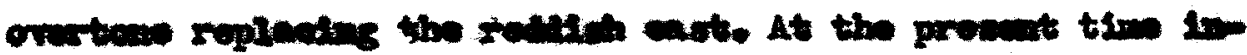
anstary aenaside both typar a blue. 
$\operatorname{mac} x$ 
Mecording to Beneroft (3) the color of an

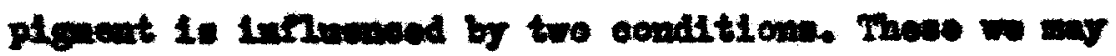

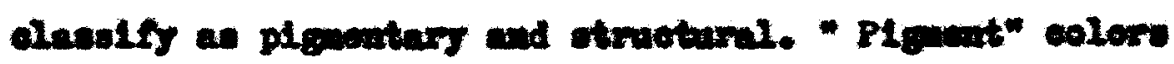

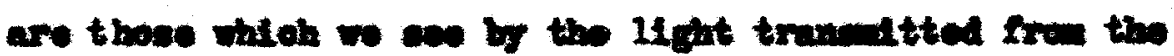

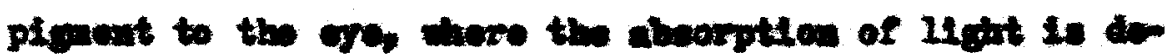

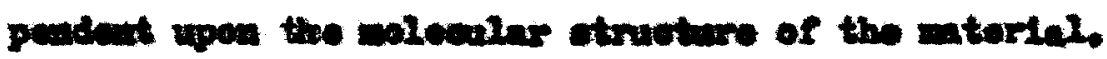

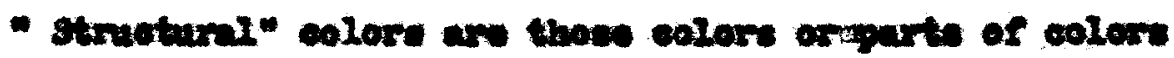

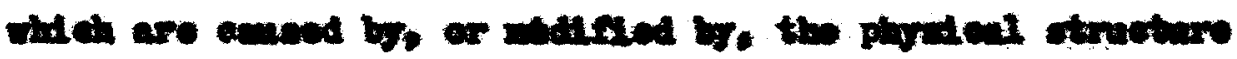

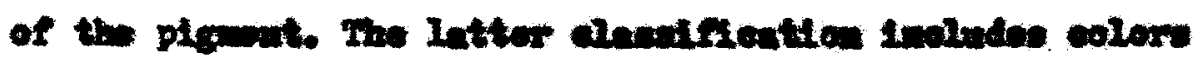

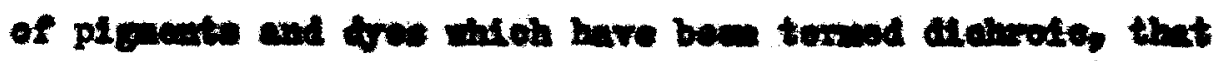

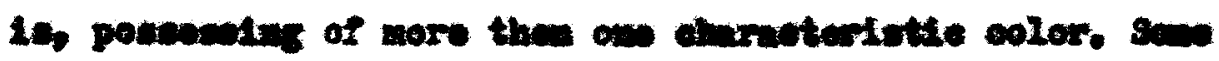

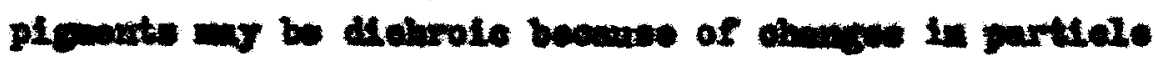
atso $(3)(20)(42)(60)$.

Plowatary arfocten

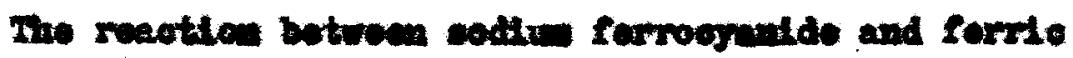
chloride any be reproasated by the equation (56).

$$
3 \mathrm{Na}_{q} \mathrm{Fe}(\mathrm{CN})_{6}+4 \mathrm{FeCl}_{3}-\mathrm{Fe}_{4}\left[\mathrm{Fe}(\mathrm{CN})_{6}\right]_{3}+12 N_{\text {adel }}
$$

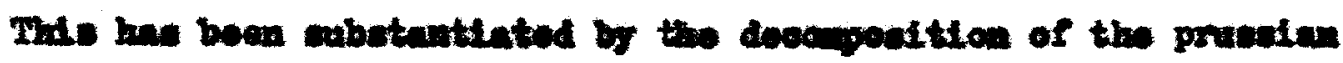


9

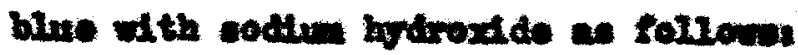

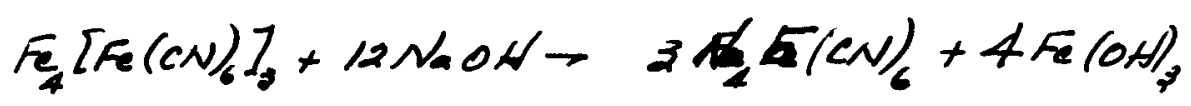

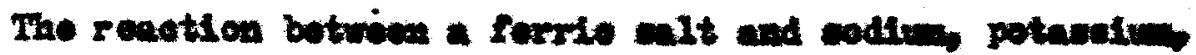

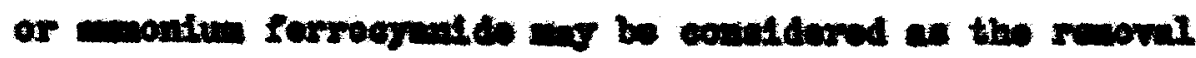

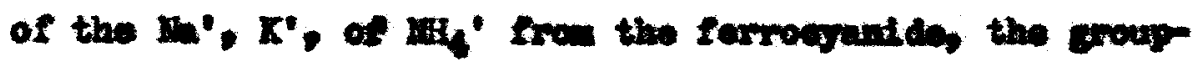

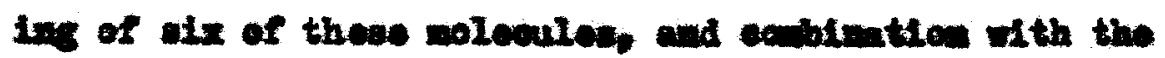

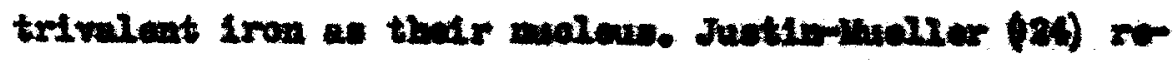
provente thite at eallowe:

$$
\begin{aligned}
& F=-(e N)_{3}=3 \mathrm{Na}_{4}
\end{aligned}
$$

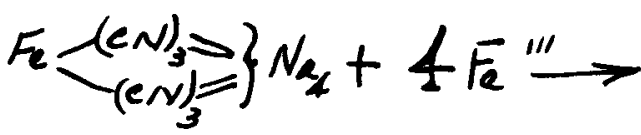

$$
\begin{aligned}
& F e-(e N)_{3}=\left\{N_{4}\right.
\end{aligned}
$$

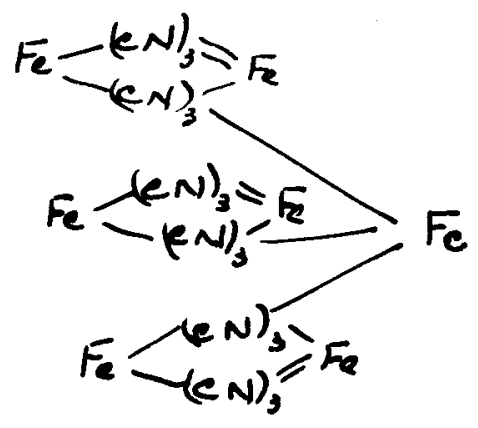

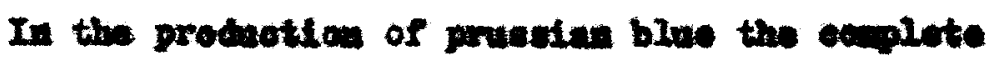

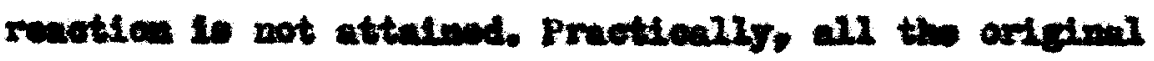

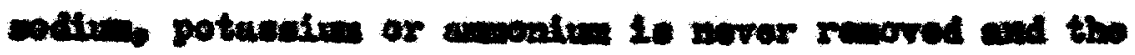

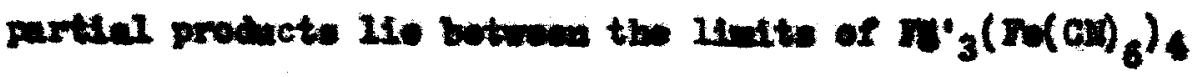

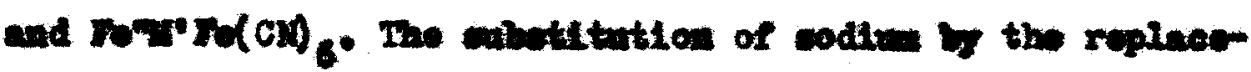
nut of trivaleat irea frem the andere of the triforit-

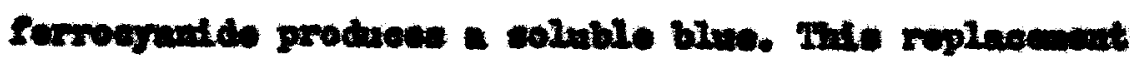


mov realt in a struotural formila en

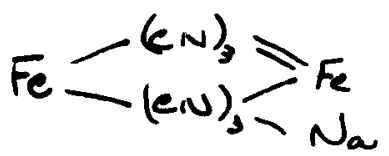

Juntim-lavelior (24) produced the oorromponding celd by

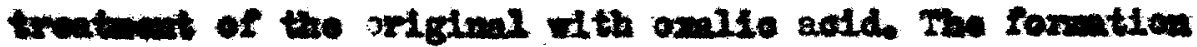

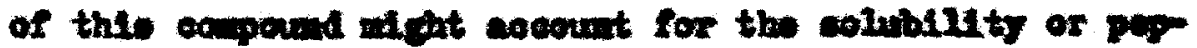

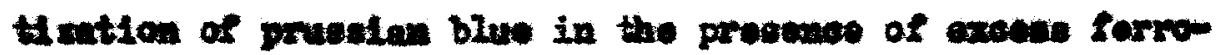
oranide.

Tho conalderatien of a struobural formile Por prusedian bive indieatee that:

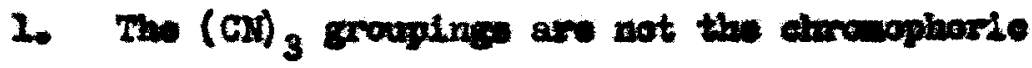

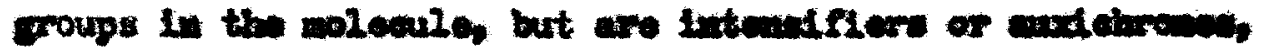

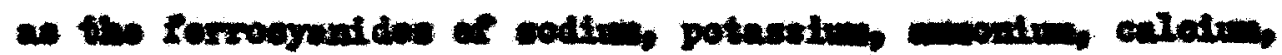

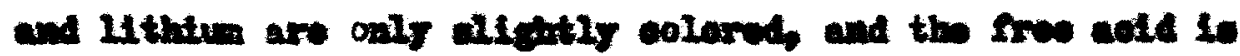
inito (36).

2. The Intornal iron (Fo") is not the color farding

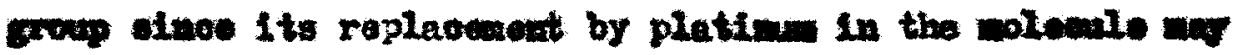

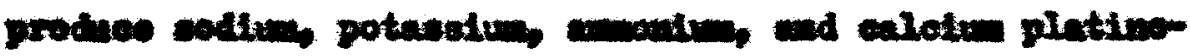

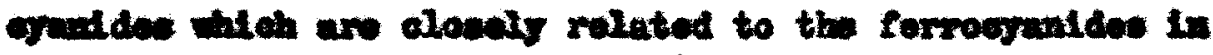
color and otructare $(44)(55)(56)$. The intermedtate wite

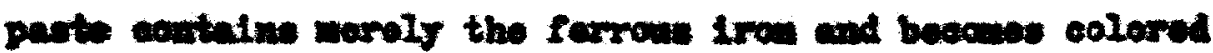


anty addation.

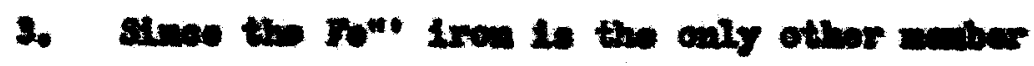

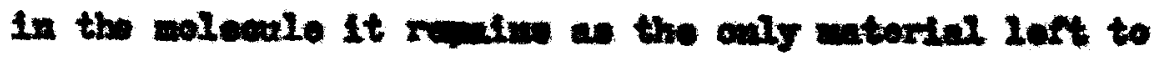

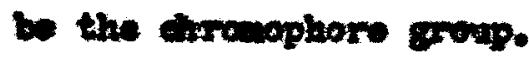

In the ckrweture of the bine pifpect, eaverding

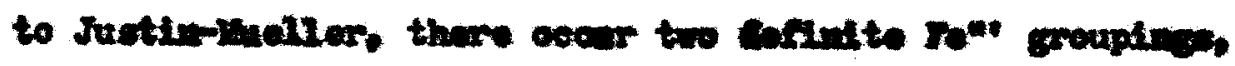
anists

$-(e N)_{3}-F_{2}=(e n)-(e N)_{3}-F^{2}-(c N)_{3}$

The Anrophowe no be ather ow of both thowe grouph. It bae been found that the replacenons of part

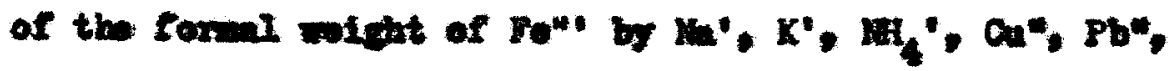
and he ba a marked afreat upon the color of the realt-

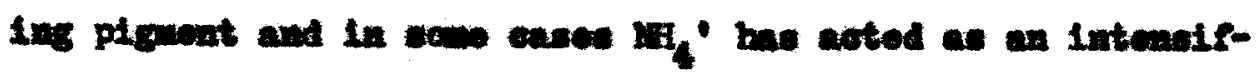
Ifr of the oolor (18) (53). The lntrodation of as ton anch

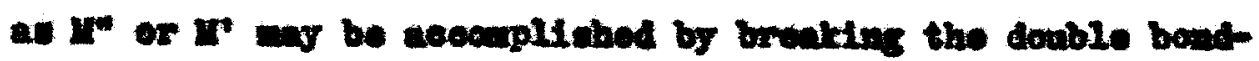

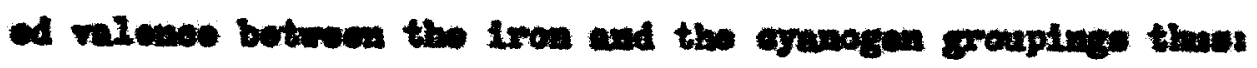

$$
-(C N)-F e=(C N)+2 N)^{\prime} \rightarrow-(C N)_{3}-F_{N}-(C N)^{\prime}
$$




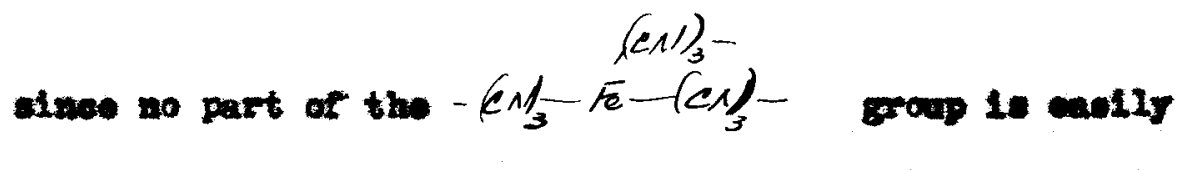
replaceble. The introduction of tho woworalent len into the pruesian blue moleoule tende to produce tho undman anount of interaity becesues of an Inorenso in the muber of alromophorle groupe present. Henee, for the production of an Intenwe blue a matim anount of monowilent ion

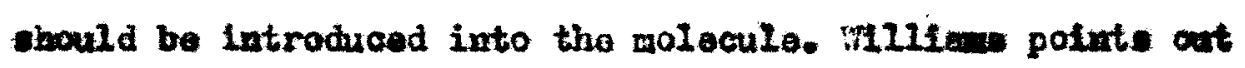
that thoee blue pionerte whioh comtain IIttlo N', $K^{\prime}$, or Mf are not in dewand by the induotry. for thes are not oo brilliut as those oontaindeg relatively largor mounts of thowe nemes:

Turabulle' Blue is elosely related to Prussia: Bine. The former is a ferrofarmoranie wille the latter

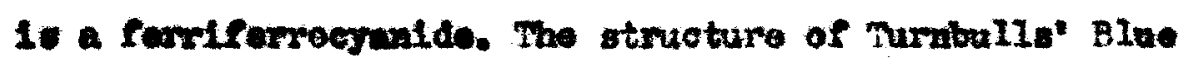
ascording th Juetin-kuelier (24) la:<smiles>Fc1ccccc1F</smiles> 
and troatmont with sodiun hydroxide produen the codive ealt of hydroforriogranie aeldt

$$
\begin{aligned}
& F e=(e v)>F_{e}
\end{aligned}
$$

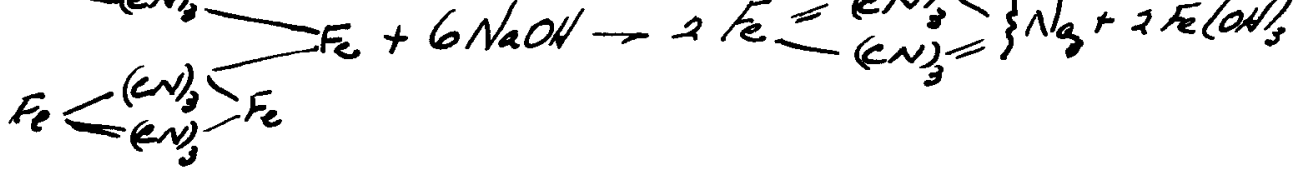

Thif sodium ecopound is rod, bat tho iron salt is light blue. Comparison of the two itructural formine chowe a

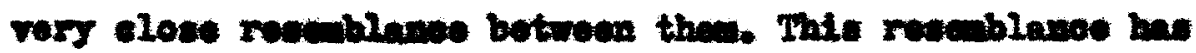

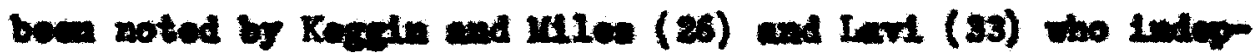
endently found wo otrwothural difforense butwean soding, pot-

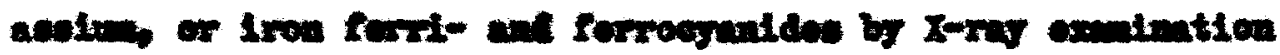

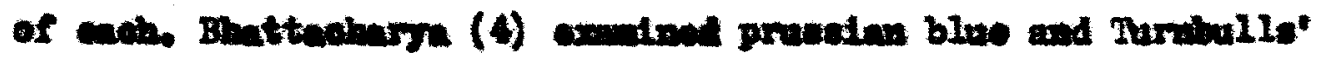

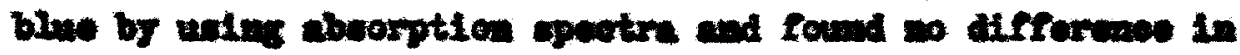
thoil itrueturrat.

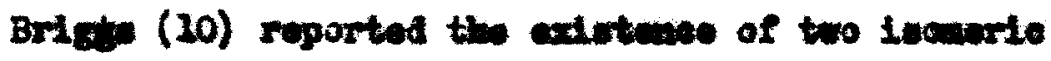

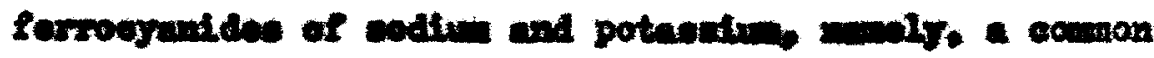
form and a $\alpha$ form thish nay be propered tron the $\beta$ by

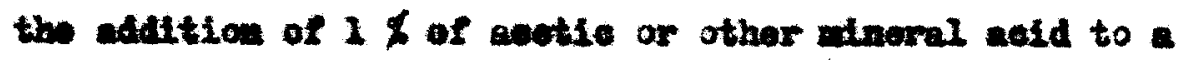
saterated volution of the forrosyande. The addition of altall or eganide to the $\beta$ vill resomport it to the $\alpha$ form.

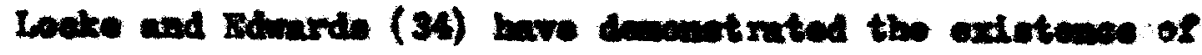


two inemorle forwe of the forrterauldes of potandive and

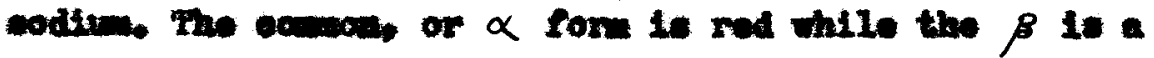

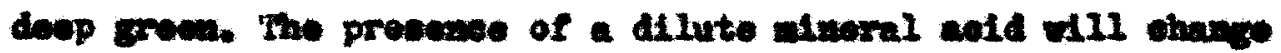

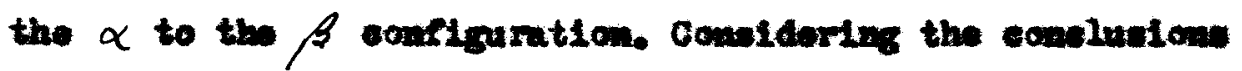

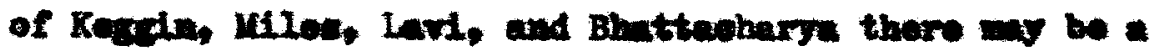

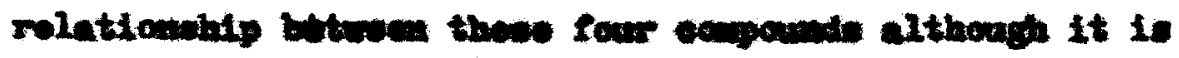
etili opere to aneotion.

Struotural Bffoeta:

mon ligat otrikes en objeot, wach as a piganent particle in a lagquer file, it is dividoe luto a nuber of ocomponents. ( See Flgare 1) Tho peneil rorlected almont

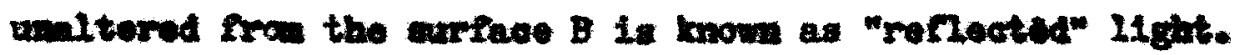

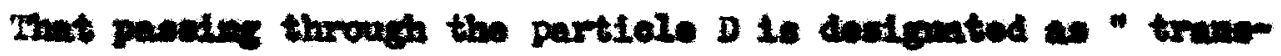
atted * Light, wile $c$ is the portion wioh is profocted from the interior of the partiele. This is dentgented an

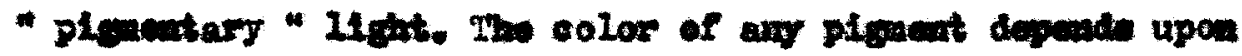

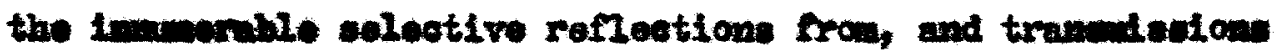
through the partielex. If the plonent powder prosonta a asooth arface It does not appear so pure in eolor as when roush Loose pakins peraits a proter proportion of the ineident

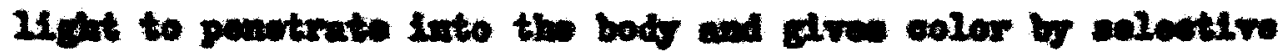




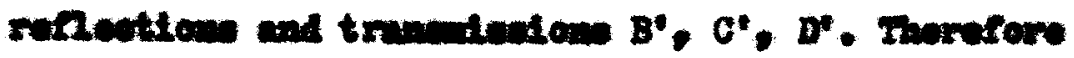

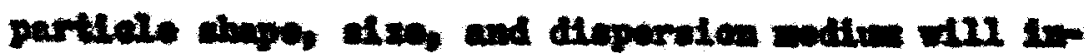
Nuence the affect of inaldent 119t.

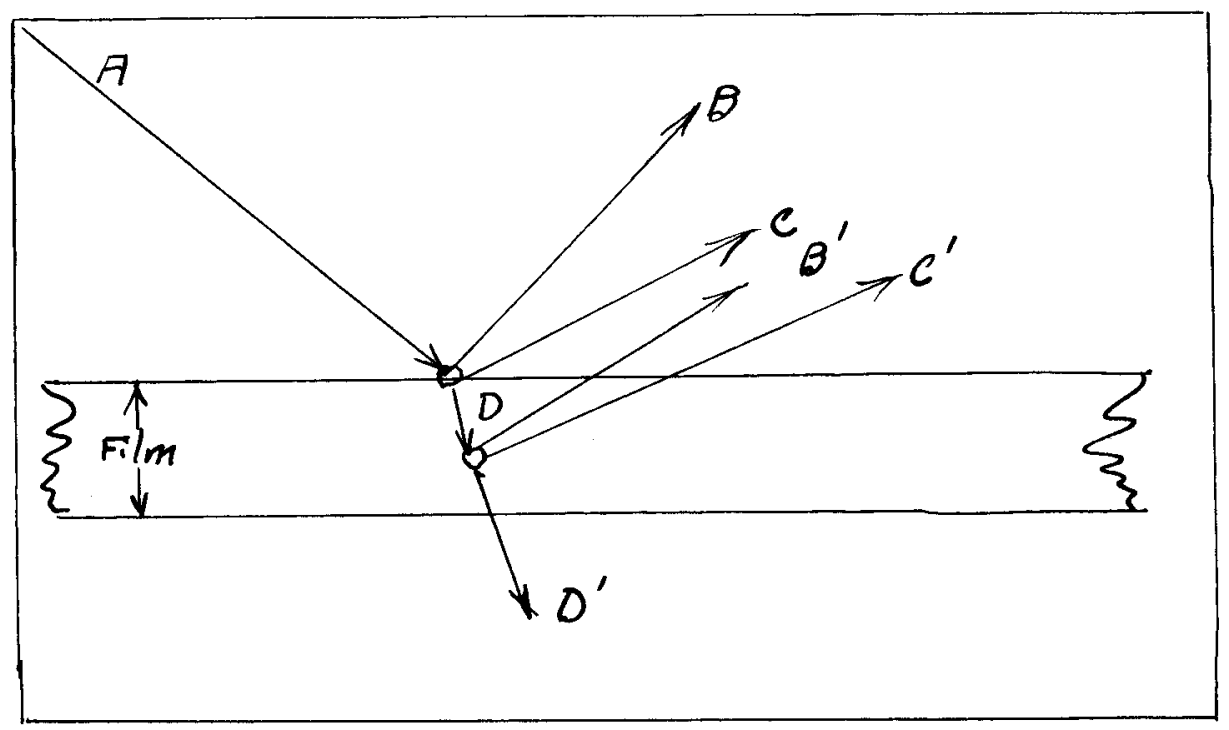

Figure 1. Path of Incident light through a Pigmented Filim. 
ExPTHETHALL 
For the Inberctery prodnotion of the colore a

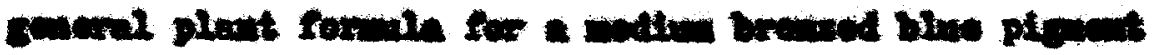

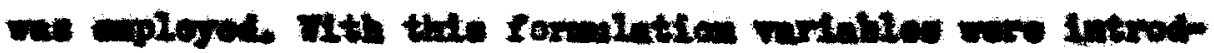

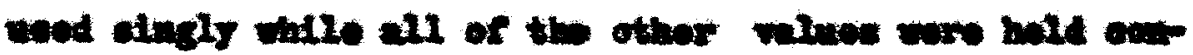

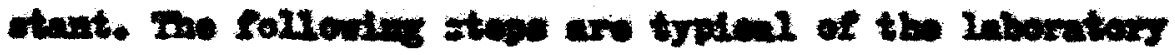
provocurve

Thirty-fow thowndithe $(0.034)$ of a mal of

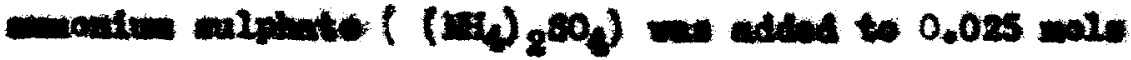

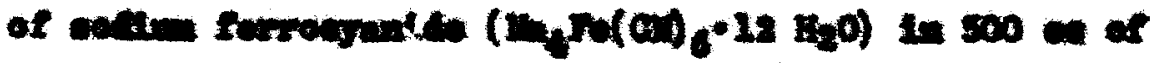

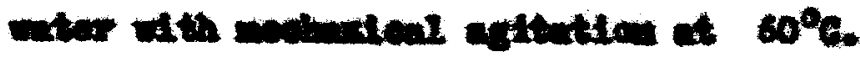

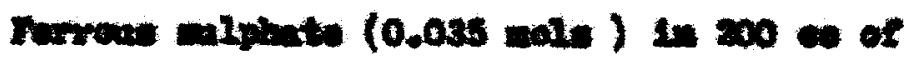

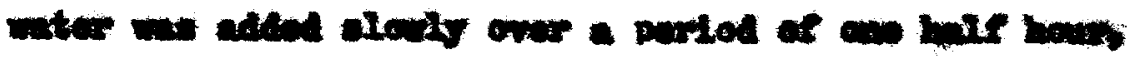

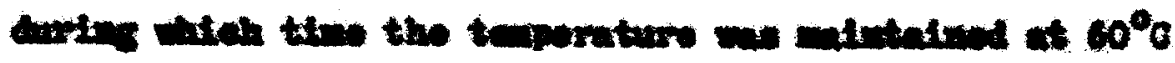

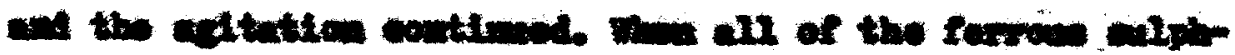

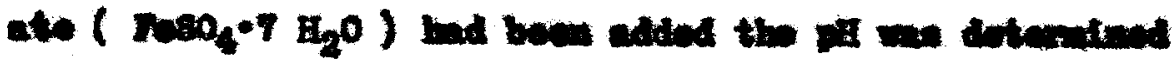

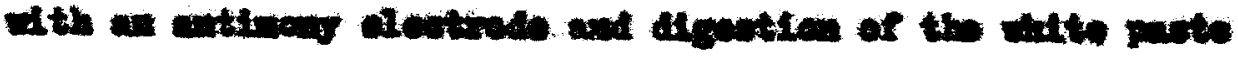
continaed at $60^{\circ} 0$ for mother ble bour.

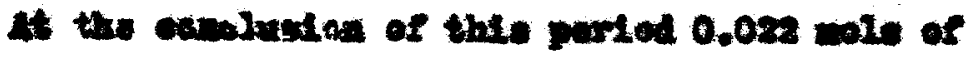

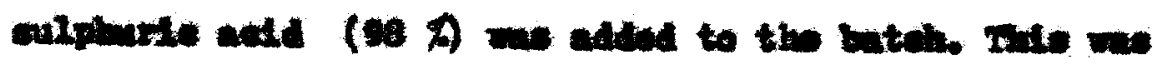

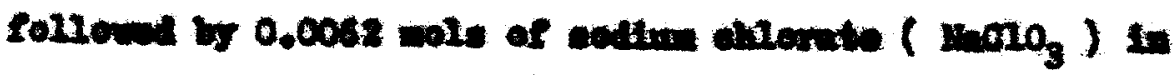

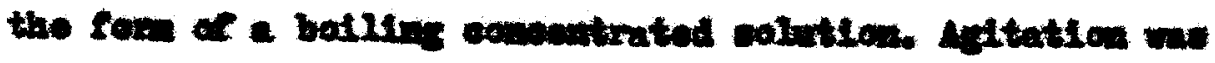


contimed end the temporature mintalnod at $60^{\circ} \mathrm{C}$ mrinc a mobequent male hour digortion. It the elose of the period the pH wo aglin taken and the plonont allowed to sott1e.

The plowent wat raked by deeantation until only traoes of $\mathrm{SO}_{4}$ " remined in the wail water. The plo nout we filtered on a metion fumel and driad at $50^{\circ} \mathrm{C}$ In the orou. Thon dry the eako wa ground in an agate

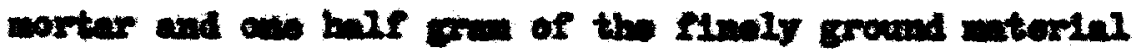
wen dioporeed in blow enotor oll aesordiog to the nothod of Cardnor (16).

A vienal ocmpuricon we mede for brouse and toptops. The tinting otrongth of the semple me detorainod by the onthod of Cardenr (26) and cropreneed as the ratio of the wifits of sample to the wolght of at arbitivary

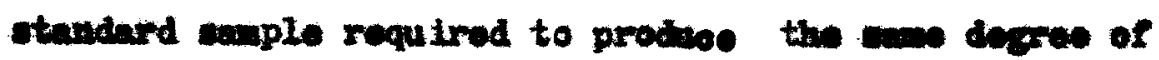
tint in a dofinite weight of sine white. The oll ebeorption of the piencut wat dotermined aceording to the nothod of Bartell and Hormbergor (20). The relative hardnose of the

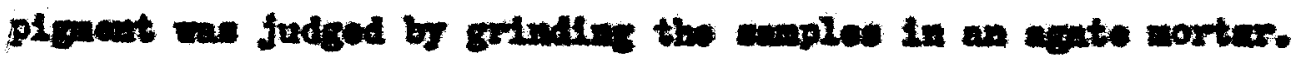


The varlables Invoetlgated worot

1. Tumporature

a. of the formation of the wite peste intermadiate.

b. of the oxidation of the rowltant intornodlate paste and eaberquent digortion.

2. Variation of the enculim alphate to cadium forrom aranide ratio.

3. Nefet of alrtitution for amonim alphate

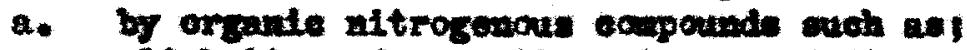

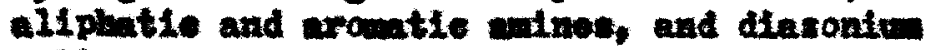
calts.

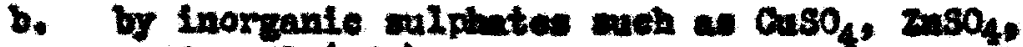

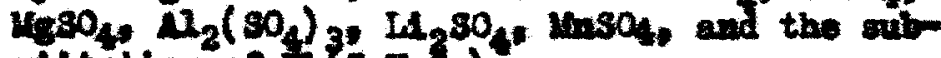
stitution of $\mathrm{Pb}_{2}\left(\mathrm{C}_{2} \mathrm{~F}_{3} \mathrm{O}_{2}\right)$.

4. Uothod of Oddation

a. addition of the eamon oxidunt, sodium ohlorate,

b. we of varlous orddsting modts,

C. amount of oxldizlng agut aoed por mol of codin forroegande.

5. Uothod of raming the interwadinte white paste

a. rarietion in the consentration of solutions of soust itavets.

b. ordor of rosent addition,

c. Cornation in noutral nedium.

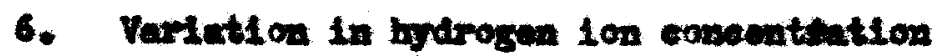

a. of the formation of the interwodiate white parte,

b. of the osidation of the intormediate paeto.

7. Ferot of addition agonte to the ferrogyends solution

a. codive forriognatis.

b. rodtum buntdo.

8. Xeray invothentlan. 
9. Hothod of aryine

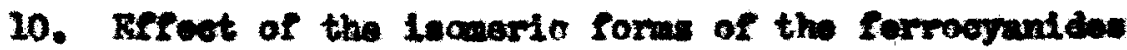
and formegnaties on the bronzing of the ploment.

11. Partiale ise of varieat ble pignoute.

12. Effect of dieperrion viniels.

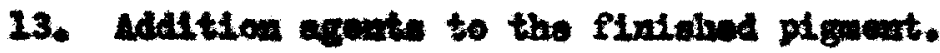

14. Plgnontation in Lequer Nin: 
$\mathbf{a}$

DAFA AND RESULTS 
Tuppratures

4 etudy of the affeet of teaperature upon the

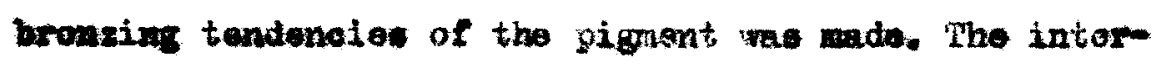
modiate wite pastes wer formod at $0^{\circ}, 25^{\circ}, 45^{\circ}, 60^{\circ}$. and $100^{\circ} \mathrm{O}$, and the aboequent oxdationg were earried ant at $60^{\circ} \mathrm{C}$ in all oases. Very little variation in the mount of brouge was notod botwoen the plgnente prodwood, wieh would indicate little effoct of this variable. Dhos the terparature of oxfiation was changed yith the san paste forming teapereture a vide ramiation in the rod cat was moted. The ohunge in the bronse anet cautud by the varlat10n of the oxidation temperatare is now in gijure 2. All these eaples wore disperged in blom oneter ofl. Oxldation at the higher temperatures produod soft blue pignonte. Theve were very high in tinting etrength, relatIrely bigh in brouse mas, and low in all abarption. Those oxideed at lom temperritures produeod bard, low tinting treagth, and lese bronzy plgments which however bad an inereased oll eborption. An optinam teaporature for the ox" Idation wa found to be areund $25^{\circ}-30^{\circ} \mathrm{O}$. Oxddation at the temperature produced a blue piganeat which is alnot free from bromse, of medium hardnoos, and with a ful dogree of 
tinting strusth. The rogults of those rane are chow in Table I.

It temporature abov $60^{\circ} \mathrm{C}$ the introbuetlon of

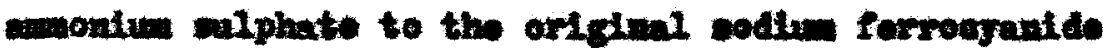

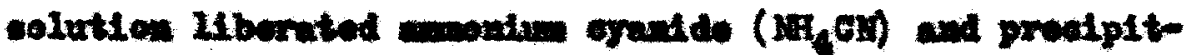
ated rarying wounte of a mil groen somplox. Wiltem (56)

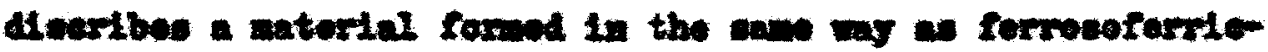
monter-ferroegnatdes

$$
F_{E_{2}}^{\prime \prime} F_{e} "\left(N H_{4}\right)_{0}\left(F_{c}(C N)_{6}\right)_{4}
$$

A maple contalining approvinble mownte of the grena proelpitate we dividod oquelis lite two gartis. The first wa filtered throvet a double zayor of filter papor on a Bechaner

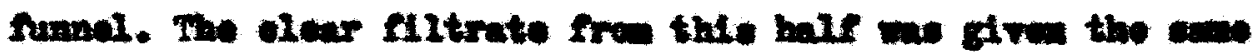

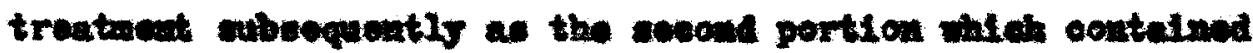
the complex in anponation. Sanplea of both final plenento wore found to whor the vale anount of brenup.

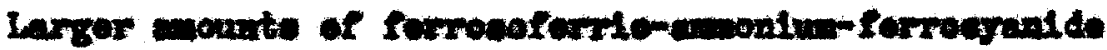
wore propered in a eimilar maven to that dineribed previoualy. The exoplex, aftor arying, wa dioperond with a anple of non-

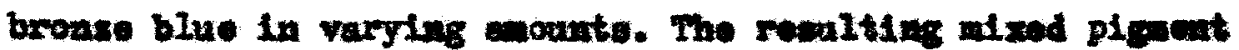

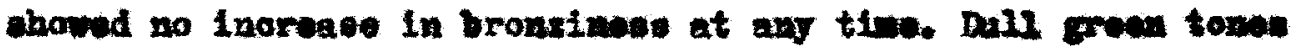


TABL I

Brrect of Tuparature Fartutiou.

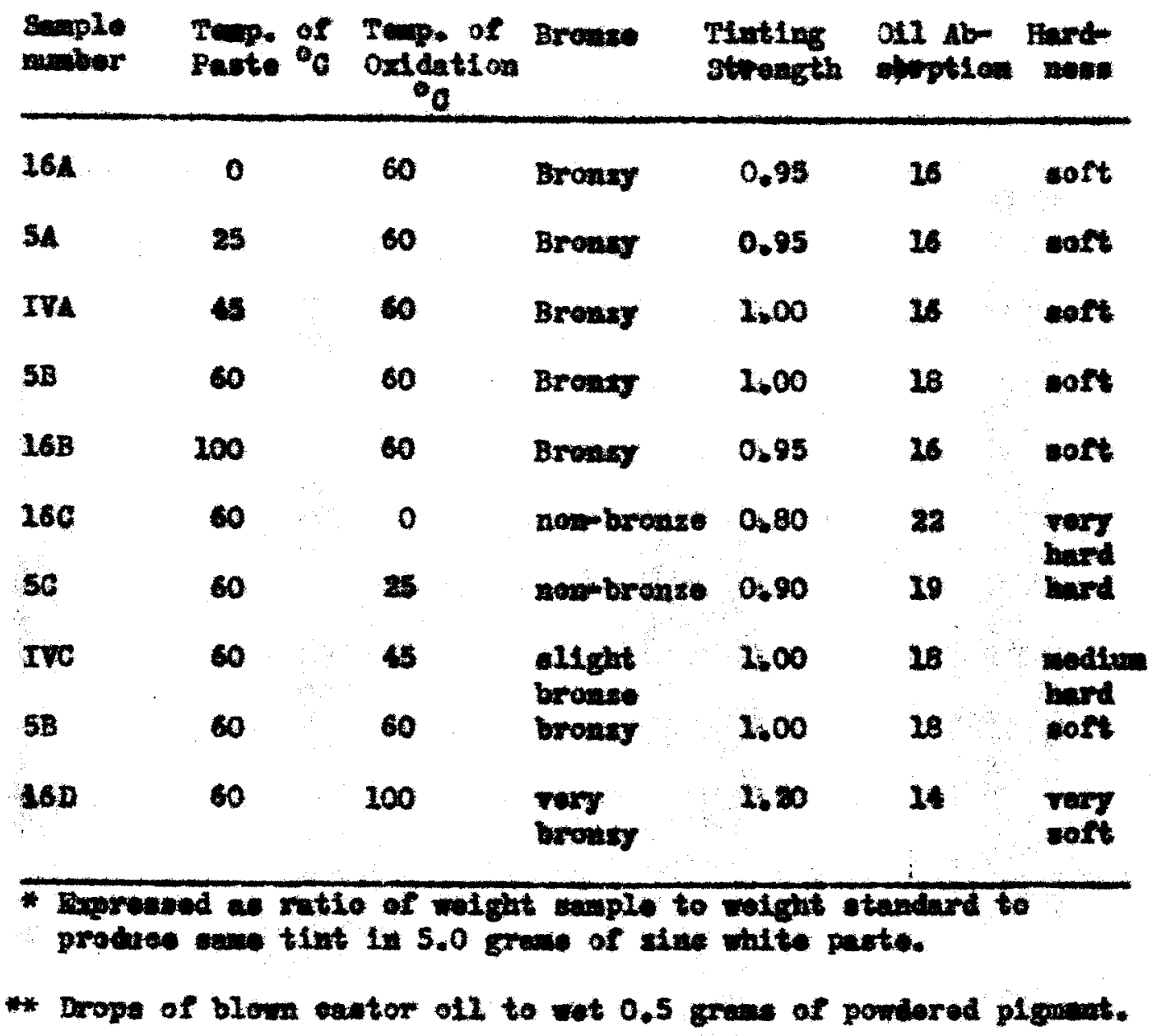




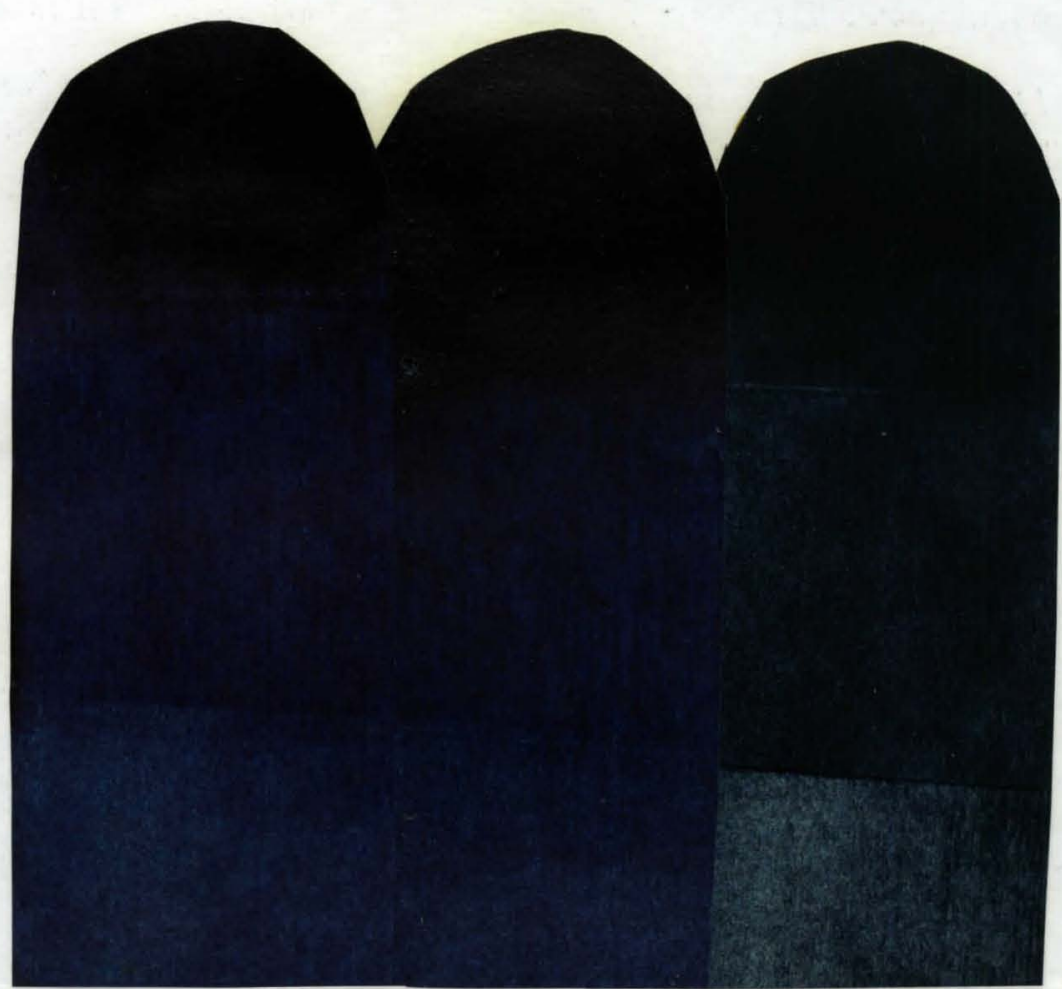

Figure 2. Ifffect of Temperature of Oxidation on Bronze. 
wore notleed when the wolght of the ecoplex wo equivelent to the witght of the blue p1gnent wead. The effeot we wot

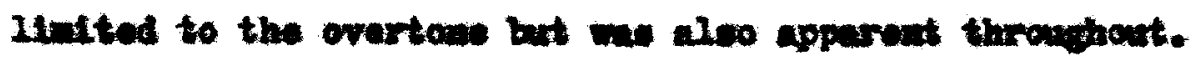

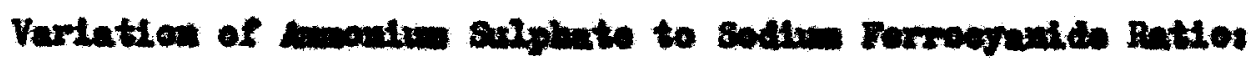
The vartation of the enowitu alphate to sodive

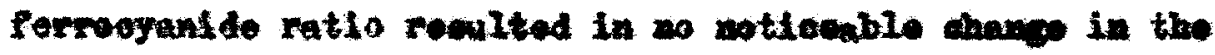

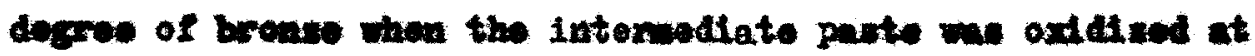
the bigher teaporatures. Howover if the wol ratto of anowilu

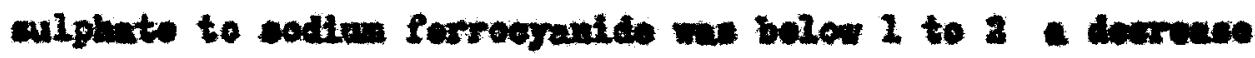
14 the tinting strongth and brillianog wos notod. At the lowar

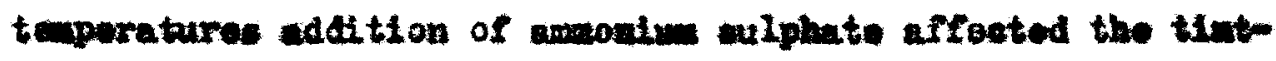
inc etronsth. Nom-bronze blues propared at $25^{\circ}-30^{\circ} \mathrm{C}$ abored a

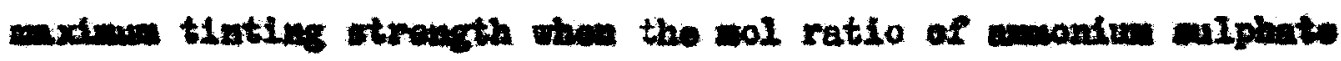
to sodiv forroeynaido was 3 to 2 . If this ratio was oswooded no additional afroet was noted on the pigment. ( Table II) Analyaie of the finimed pignents prepared Ith varying monive alphute addition to tho sodive ferroegramide showed that the anount of monium ion remalining in the pignent was

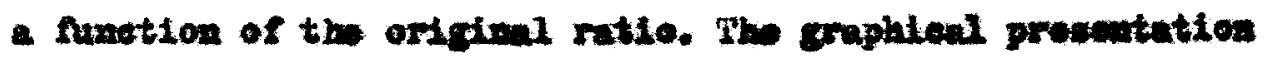

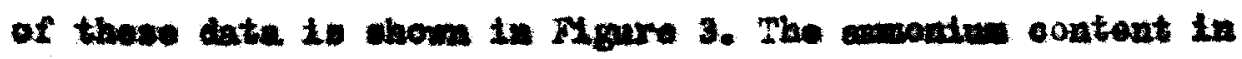
the plgavent whon tinting strongth was hiphont we fould at 2.25 to $2.5 \%$ 
TABLS II

Variatios of twoontre suphate content in Fonmalativen.

\begin{tabular}{|c|c|c|c|c|c|}
\hline sumber & $\frac{\text { not: }}{\left.4 t_{4}\right)_{2}}$ & Brovate & $\begin{array}{l}\text { Muting } \\
\text { Strongth }\end{array}$ & $\begin{array}{l}\text { OLI } 1 \\
\text { earptien }\end{array}$ & $\begin{array}{l}\text { Hord- } \\
\text { none }\end{array}$ \\
\hline 1* & 1.39 & bingesey & 1.00 & $\infty$ & $\operatorname{son}$ \\
\hline 4 & $\begin{array}{l}1.39 \text { at } \\
\text { Mahr"t: }\end{array}$ & $\begin{array}{l}\text { bronditer then } \\
\text { seit } 1\end{array}$ & 0.95 & 20 & ast \\
\hline 5 & 1.00 & $\begin{array}{l}\text { Iene browe: } \\
\text { thep } 1\end{array}$ & 0.90 & 20 & mart \\
\hline $6 *$ & 0.50 & $\begin{array}{l}\text { low breane } \\
\text { then } 5\end{array}$ & 0.85 & 20 & eort \\
\hline anw & 2.00 & alght broute & 0.90 & 28 & hant \\
\hline 17\%: & 1.00 & mose as 20 & 0.95 & 28 & mara \\
\hline $23 *$ & 1.39 & $\operatorname{sanc}$ es 20 & 1.00 & $\mathbf{p}$ & veditum \\
\hline $2 * 4$ & 3,100 & $\operatorname{sen} 20$ & 0.85 & 23 & hare \\
\hline
\end{tabular}

- Taponture hal et 600.

** Temperature hald at $25^{\circ}-30^{\circ} \mathrm{C}$. 


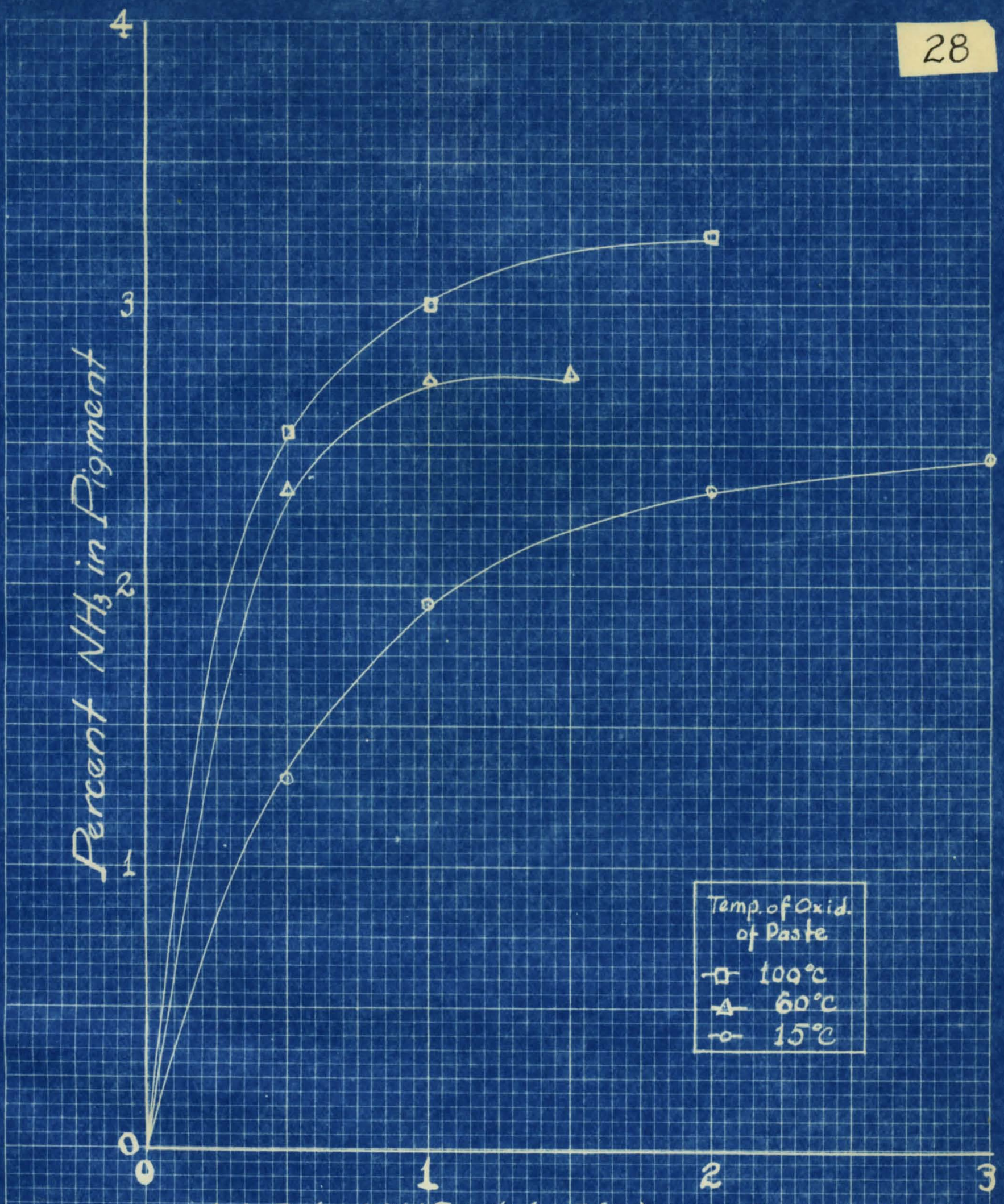

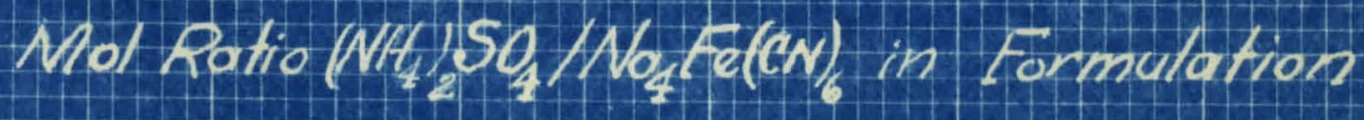

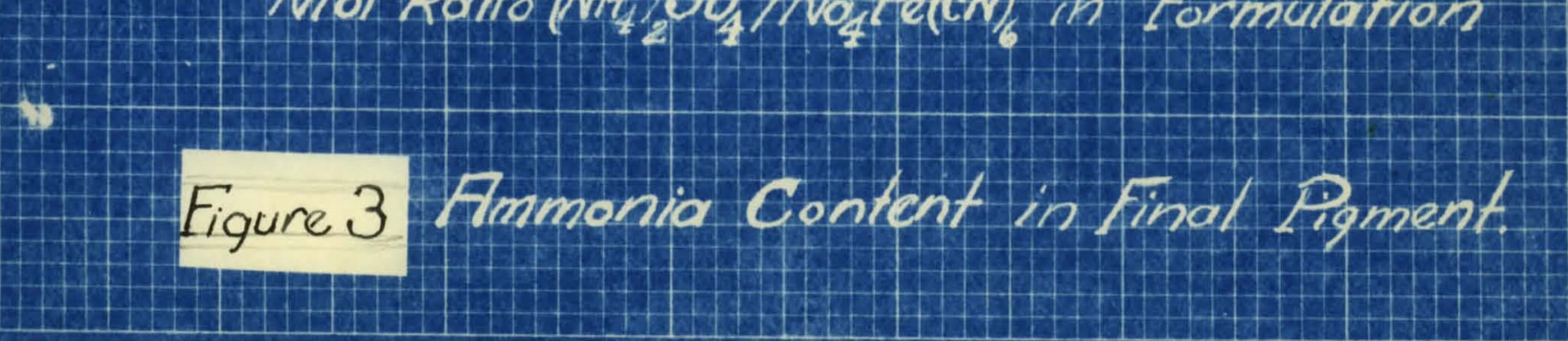




\section{P1gunto propered treo dodtum ferrograte}

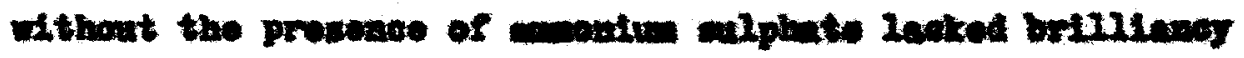

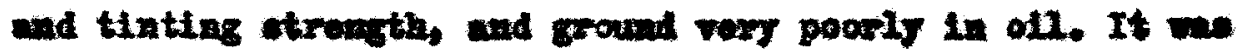
noted thet the addition of water to the oll diparond plowent

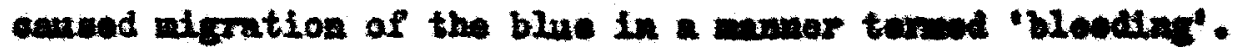
A4 abstitute for anonim anlphate and forrous

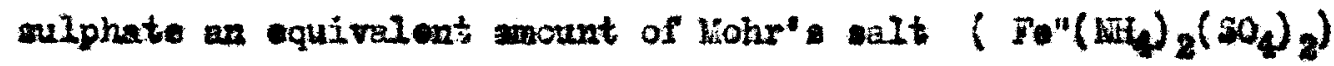
was ased. The rewult was ocaparable with the stadard but showed elightly more bronse. Anines and roleted ocmpornde, both alipbatis and arometie, rere mbatitutod for tho amonIv Ion in an attengt to deterifin ine effoct of largap froupe in the ferrocyande molocule. In genoral tho allphatie groupe presented a more bronzy appearance than the aroustle froups, but the brones wa in no case far afferent from

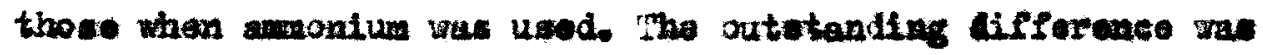
an agparent trend toward a grow overtono. A blue pignent ande in the presonce of ures we exooptional in this reopent. ( Table II) ( Figuro 4).

In one experimont toluldine nas dinsotised and the diasontua ehloride me made to rwat with sodium forrocyante. Terrous alphate was udded and the paste oxidized in the vawel wamer. The plgaent was grocn-yellor in color and did not rom 
TABL III

Iffoct of addition of orgatie hines in Plaes of inorair sulphete.

\begin{tabular}{|c|c|c|c|c|c|}
\hline $\begin{array}{l}\text { Sample } \\
\text { number }\end{array}$ & andes & 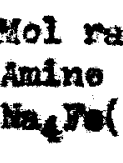 & Brouze & $\begin{array}{l}\text { Tinting } \\
\text { Strongth }\end{array}$ & ot1 ab \\
\hline $7 *$ & $\begin{array}{l}\text { dimethyl } \\
\text { antlitive }\end{array}$ & 1.39 & $\begin{array}{l}\text { medtur } \\
\text { beeme }\end{array}$ & 0.90 & 15 \\
\hline 8 & Apbur & 1.39 & $\frac{10 m}{7}$ thon & 0.90 & 25 \\
\hline 9 & urea & 1.39 & $\begin{array}{l}\text { non-bronzo } \\
\text { greon top-t }\end{array}$ & $\begin{array}{l}0.80 \\
\text { tone }\end{array}$ & 18 \\
\hline 20 & $\begin{array}{l}\text { telether } \\
\text { amino }\end{array}$ & 1.39 & $\begin{array}{l}\text { wore bronse } \\
\text { the: } 7\end{array}$ & 0.85 & 14 \\
\hline $10 B$ & $\begin{array}{l}\text { Lethyl- } \\
\text { othy } 1 \\
\text { anine }\end{array}$ & 1.39 & bransiont & 0.95 & 24 \\
\hline 100 & $\begin{array}{l}\text { diethanol } \\
\text { andat }\end{array}$ & 1.39 & $\begin{array}{l}\text { Lees bronzo } \\
\text { them loB }\end{array}$ & 0.95 & 25 \\
\hline 78 & andine & 1.39 & $\begin{array}{l}\text { nowe bronx } \\
\text { then } 7\end{array}$ & 0.95 & 15 \\
\hline 100 & predein & 1.39 & Dimiler to 1 & $\frac{100}{1.00}$ & 15 \\
\hline$D 8$ & $\begin{array}{l}\text { pmethyl } \\
\text { phonylazon } \\
\text { chloride }\end{array}$ & 1.39 & exomerellow & $m-$ & 10 \\
\hline
\end{tabular}

- Temerature hald condtant at $45^{\circ} \mathrm{C}$ throughout. 


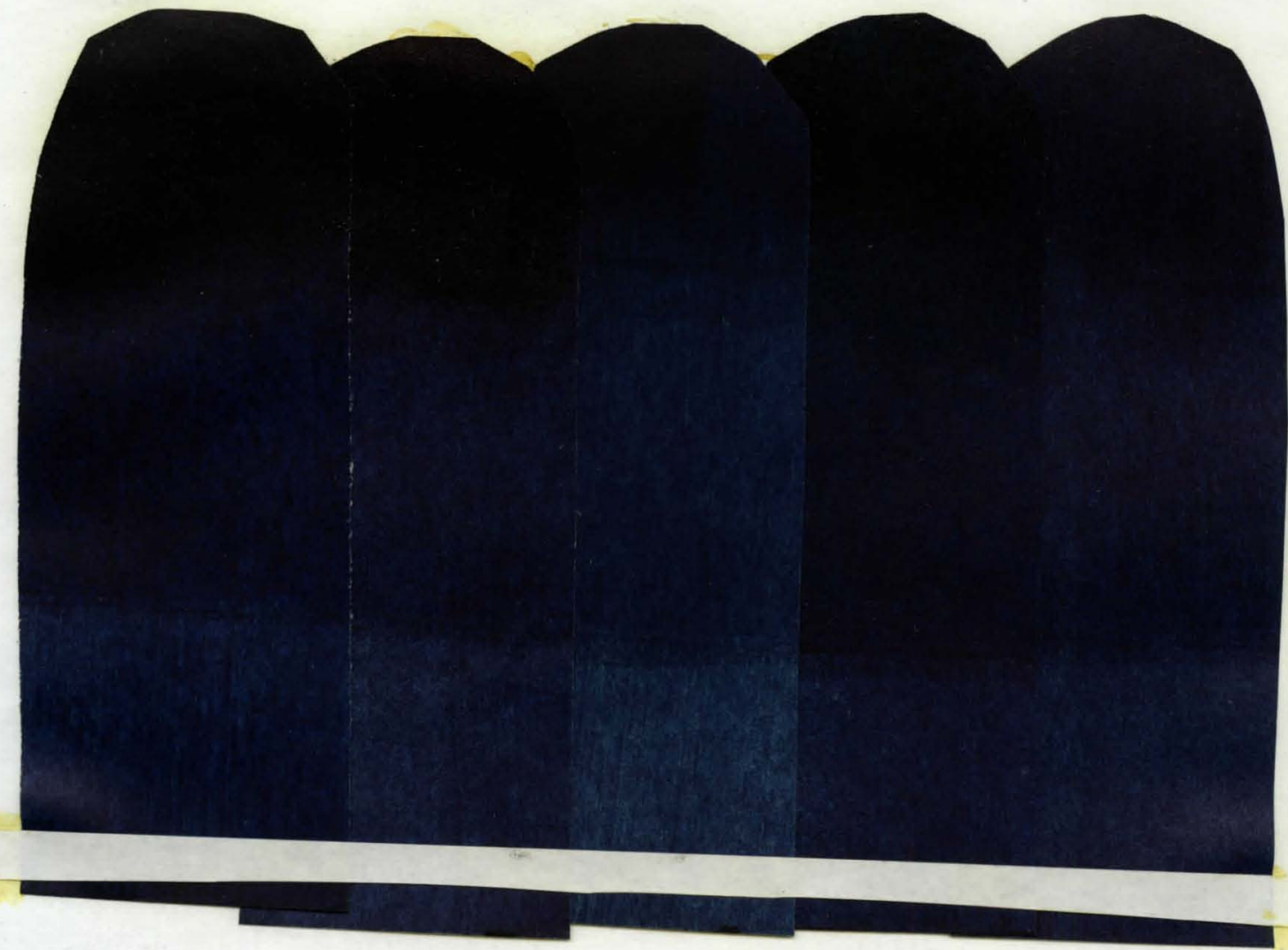

Ananoaiua dinothyl diphenyl urea
sulphate
aniline amine

Mgure 4. Roplecenont of Anomiun Sulphate by Organic Anines. 


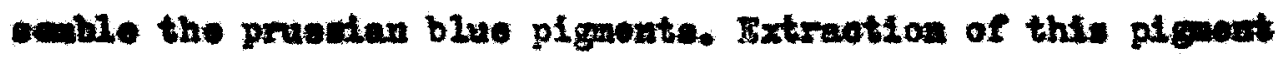

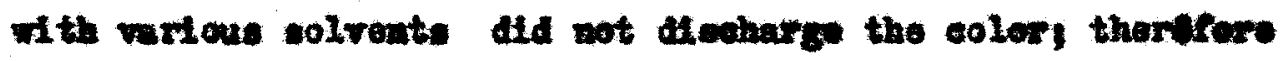
It was anowed that the tolutdine we in comblation with the farrocyanide.

Thon aluminu, oopper, zine, lead, and araonic olts

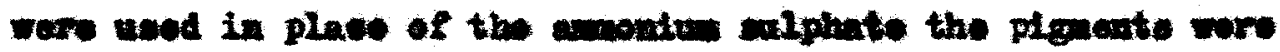

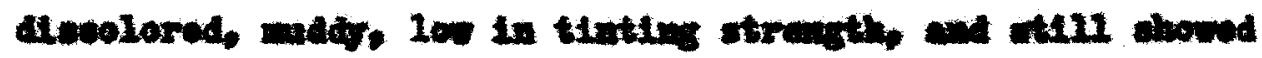

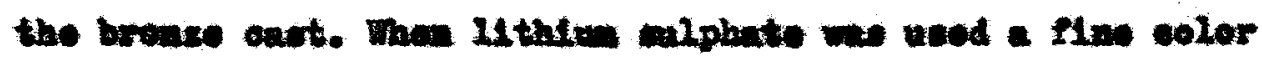

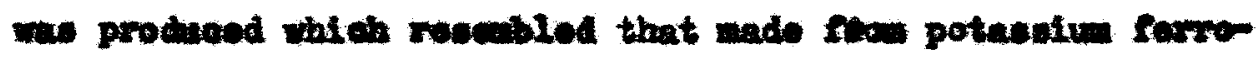

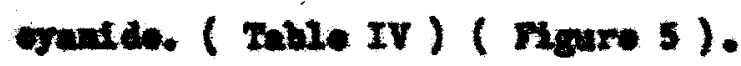

Yothod of Oxidation:

The oxidation of the wh to parte was weouplitines under unious oonditions.

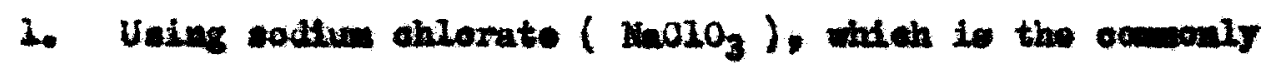
wad oxidant, the mothod of addition me variad fros the ory

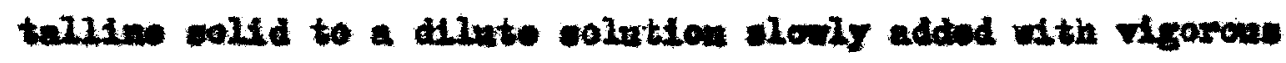

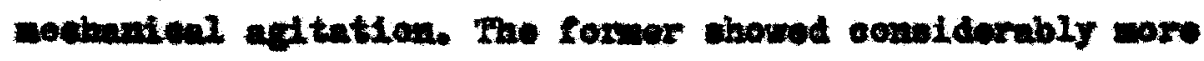
brouse these the latter. (Thle $V$ )

2. The relattre mount of odtw eblorate need was ramed

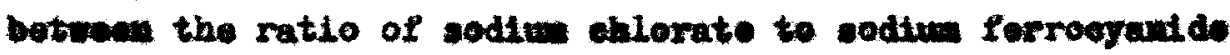
0.1 to 1 and 1.25 to 1 , but the aeatul range for the prodnetter of prancien bluce foll botweos 0.20 to 1 and 1 to 1 . 
Effect of Subatitution of Inorganic salte for mandm sulphate

\begin{tabular}{|c|c|c|c|c|c|}
\hline suple & Camporut & $\begin{array}{l}\text { Mol ratio } \\
\text { por mol }\end{array}$ & Bronst & $\begin{array}{l}\text { Mutting } \\
\text { otrousth }\end{array}$ & $\begin{array}{l}\text { al bi } \\
\text { arption }\end{array}$ \\
\hline $11 *$ & $\mathrm{II}_{2}\left(\mathrm{SO}_{4}\right)_{3}$ & 1.39 & broute & 0.70 & 25 \\
\hline 12 & $\mathrm{CuSO}_{4}$ & 1.39 & green & 0.40 & 23 \\
\hline 23 & $2 \mathrm{nSO}_{4}$ & 1.39 & $\begin{array}{l}\text { vary } \\
\text { bronze }\end{array}$ & 0.85 & $\mathbf{a}$ \\
\hline 14 & $\mathrm{~Pb}\left(\mathrm{C}_{2} \mathrm{H}_{3} \mathrm{O}_{2}\right)_{2}$ & 1.39 & Jot & 0.60 & 8 \\
\hline $15+$ & $\operatorname{cus} 30_{4}$ & 1.39 & bronze & 0.50 & 83 \\
\hline 19 & $2 n_{30}$ & 0.25 & bronateot & 0.90 & 2 \\
\hline 43 & $\operatorname{LinsO}_{6}$ & 1.39 & brown & 0.80 & 20 \\
\hline 40 & $\mathrm{Li}_{2} \mathrm{SO}_{4}$ & 1.39 & $\begin{array}{l}\text { very } \\
\text { bromes }\end{array}$ & 1.10 & 18 \\
\hline 44 & $\mathrm{Mag}_{2} \mathrm{NO}_{4}$ & 1.39 & groan & 0.80 & 22 \\
\hline
\end{tabular}

* Teperature bald conntant at $60^{\circ} \mathrm{C}$ throughout. ** Gertidrod. 


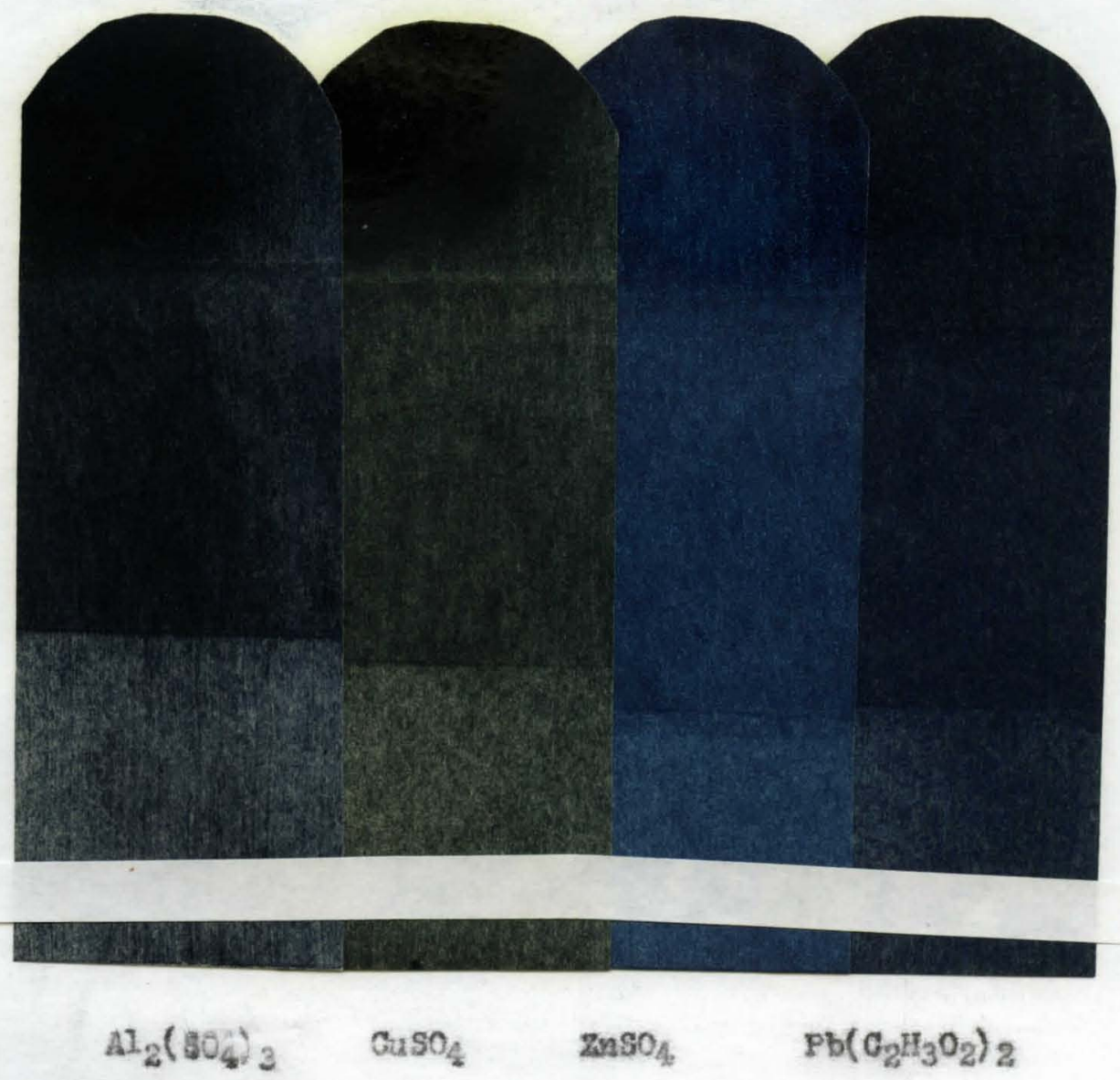

Figure 5. Bffect of Replacement of Ammonium Julphate by Inorganic Saltd. 
Das

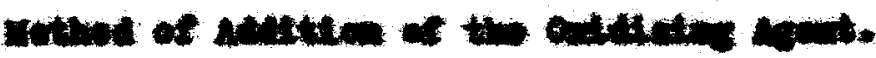

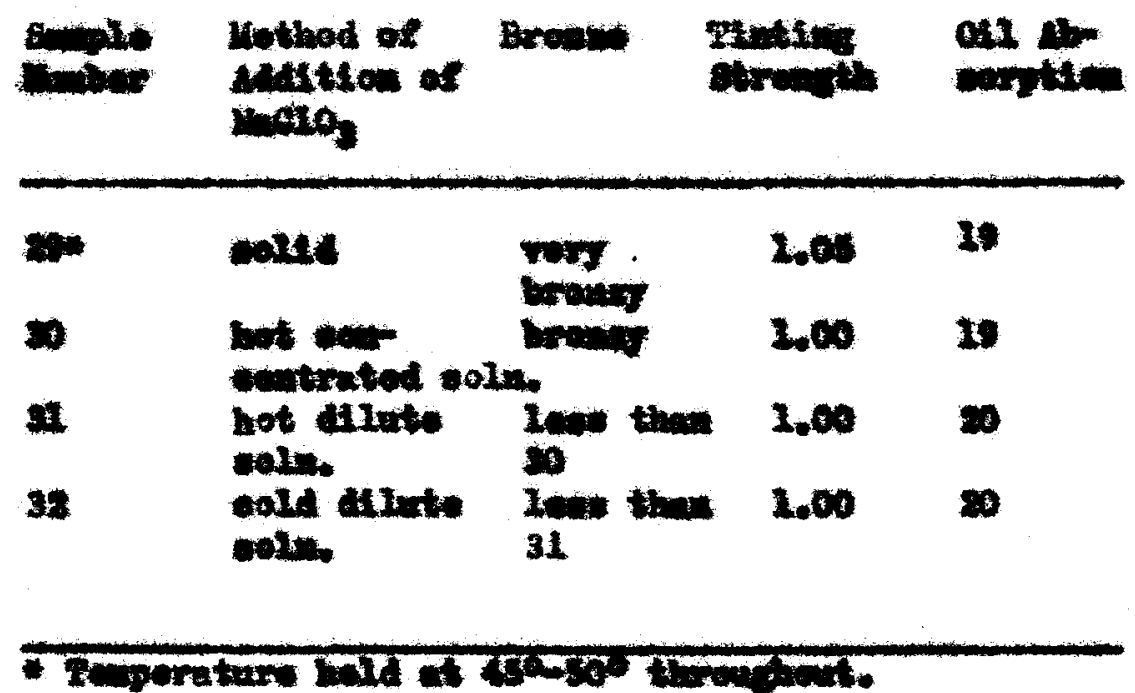




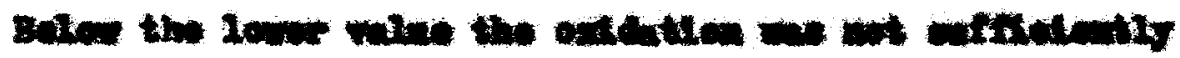

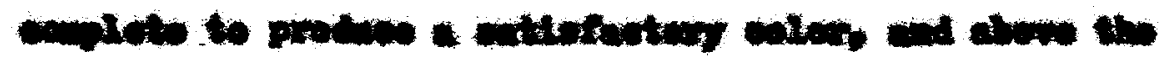

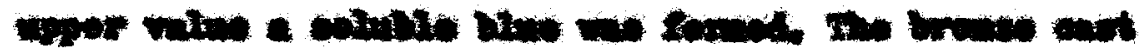

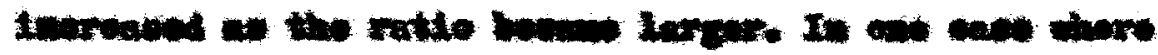

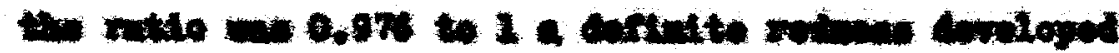

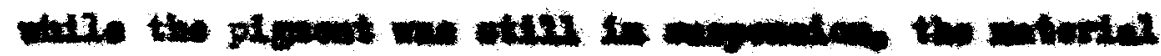

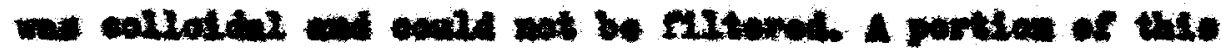

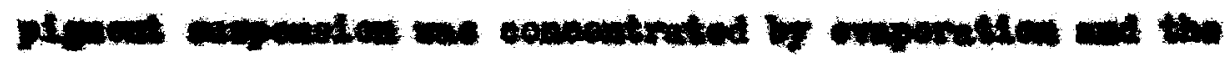

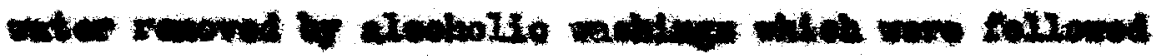

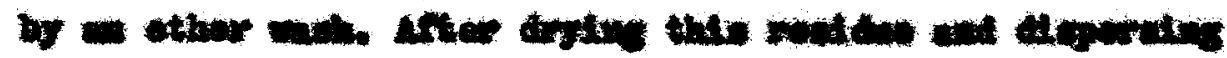

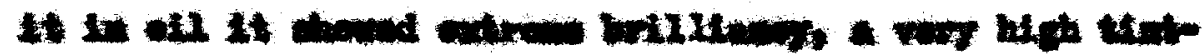

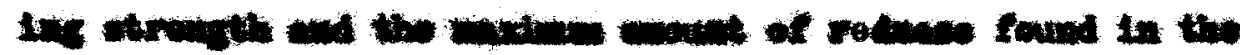

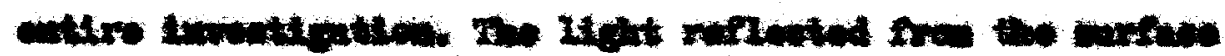

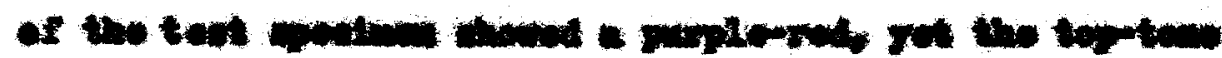

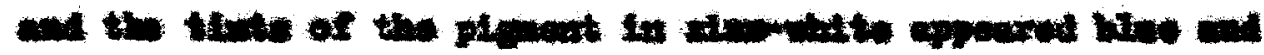

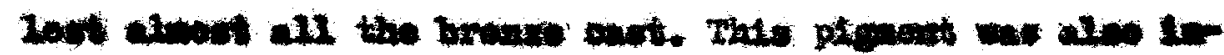

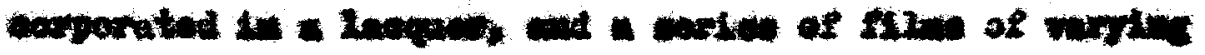

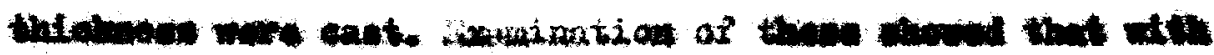

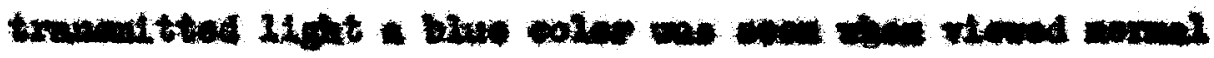

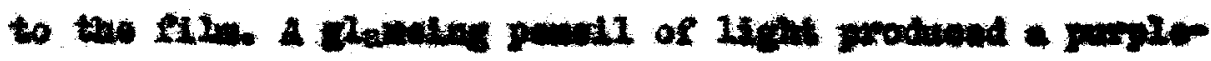

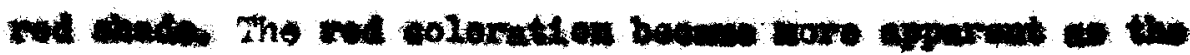




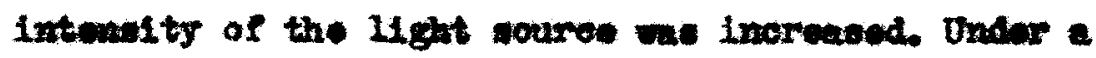
earbos are the bine is almot lont in the ligh ranected fron tho piganest particles, and the color of the apeeimen under these conditlone approeshes a deep red. (Table VI) 3. The oxdation ves invastigated with the use of potastum

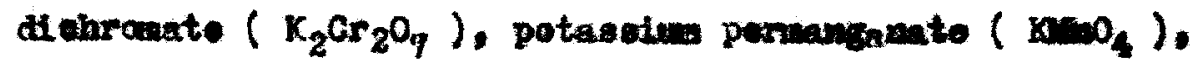
mitic actd, afr, hydrogen peroxdde, sodim mpochlart te, ( Nacl ), forrie aitrate $\left(\mathrm{Po}\left(\mathrm{NO}_{3}\right)_{3}\right)$, and perohlorie add $\left(\mathrm{HClO}_{4}\right)$. In order to reduce the various oxidante to a counon batie for comparison, 0.525 oxggen equivalente

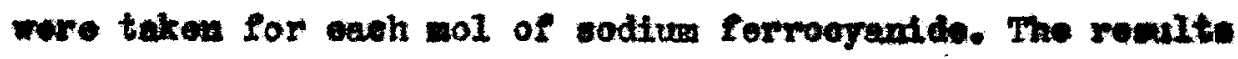
are tabulated in Table VII. The rapid addition of potactin diohromate oused a green undistono to appeer, eopelally If the oxidation were conducted at temparatures above $60^{\circ} \mathrm{C}$ The blohrouste produced the brousient blue pigmente. The nee of pormanganete produced blue ifgrante wion were jot in top-tone, black in the dry atate nad were all abaractarlied by a green under-towe. "rhe biues prepared by ustag sodium mypochlorite veried in the iegrea of bronze ovea with uplitate formulations. Air oxidstion mas slow and roquired 8 to 20 hours. The pigment was wask snd did not have any luatre. The uge of nitric ecid produced greon top-tones 


\section{TABLE VI}

Iffeot of Concentration of Oxilieing Agent.

\begin{tabular}{|c|c|c|c|c|}
\hline $\begin{array}{l}\text { Smale } \\
\text { Number }\end{array}$ & $\begin{array}{l}\text { Hol ration } \\
\mathrm{NhOl}_{3} \text { to } \\
\mathrm{H}_{4} \mathrm{~F}(\mathrm{ON})_{6}\end{array}$ & Broneo & $\begin{array}{l}\text { Huting } \\
\text { Strength }\end{array}$ & $\begin{array}{l}\text { C11 ab } \\
\text { sorption }\end{array}$ \\
\hline $25 *$ & 0.976 & bronsient & 0.95 & 27 \\
\hline 26 & 0.732 & lowe than 25 & 0.95 & 19 \\
\hline 24 & 0.244 & Leant brones & 1.00 & 20 \\
\hline 28 & 0.122 & $\begin{array}{l}\text { light blue due } \\
\text { oxddetion. }\end{array}$ & to inart & alout \\
\hline
\end{tabular}

- Temperature held conetent at $15^{\circ} \mathrm{C}$. 
Rffect of Varfoue Oxidzing Agants.

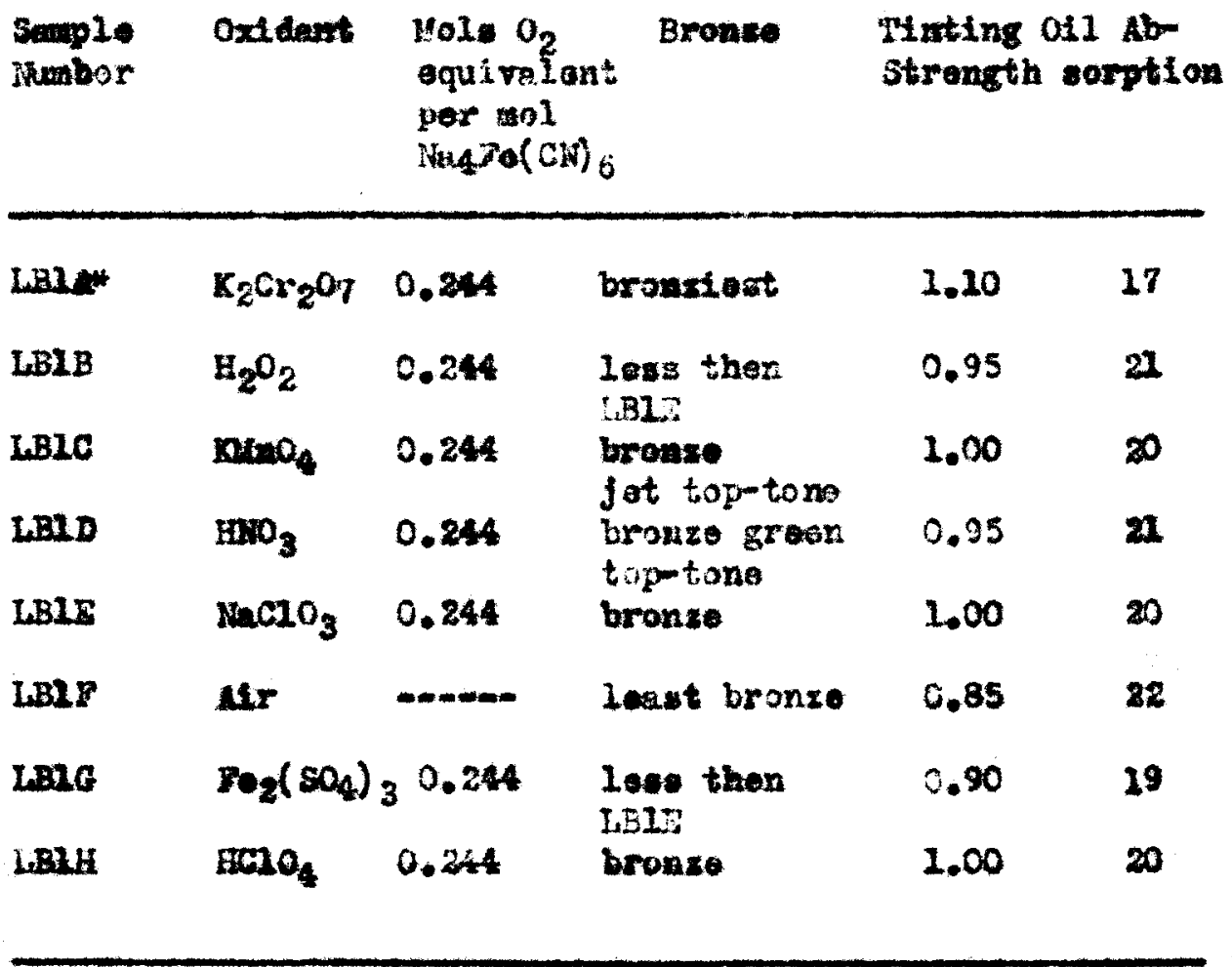

Temperature hald at $30^{\circ} \mathrm{C}$. 
around $80^{\circ} \mathrm{C}$ eould be wade to produce a greon plgout by excers adrition. The pasto wieh vas oxdized wth por

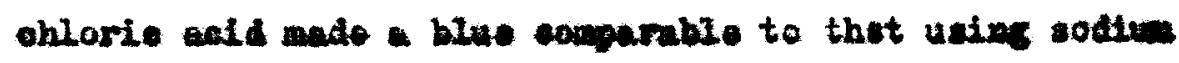
ahlorate. Tho use of forrit sulphato rasultad in a gi nont with a brown top-tono, and whea incorporated in thate chowed a grey disooloration. The resulte of oxidation rith hydrogen peroxide were comparable to those obtained wh sodiun allorate.

Weotrolytic exddation wae trted, but there mas no approciable decrease in the bronse tone when the oxication weaffered with urea, frotose, and bensaldehydo very littio variation in brone wa noted.

Conembrution of Solutioner

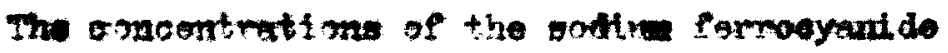

and the ferrous arlphate ware rarled, and the dilute solutlowe prodused tho brightert blues, but little effect mas noted on the bronse cent. An optinem conoentratien was found at about $2.5 \%$ sodiva forrooyand solution and 10 f forrons sulphate olution. Vory comsenirrated solution of elther

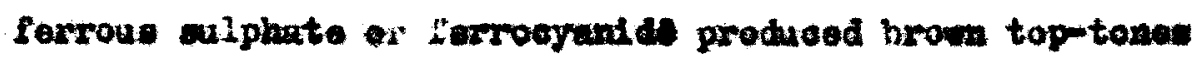
and wil wades of blue with a cearease in the bronse. ( Table VII) 
TABLE VII

affect of voncontration of solina ferrooyanido and Ferroue sulphate solutione.

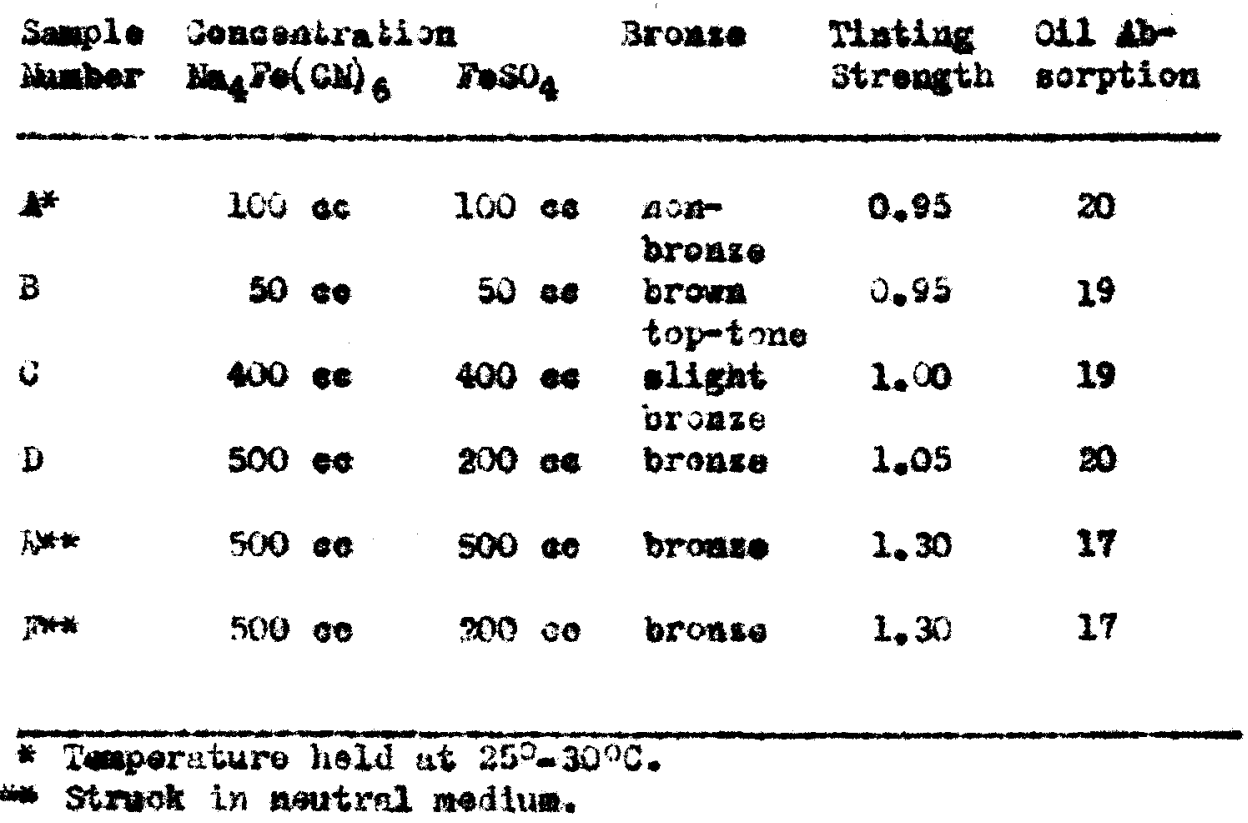


$\Lambda$ brightor biue way be obtsined at the bigher

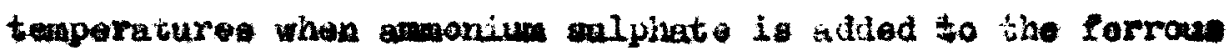
wilpiate oulution, fale additi a also prevents the formetion of the ferropoferriemoniam-ferrocyanide cxplex previouly mentiand. Ions bronse whe produced whan the sodium forrooranide solded to the forrous sulphate. Horcover, if the plf werv around 5.5 alter oxida ion there appeared a brom coloration is the finiehed pigenent. ifte rovite indiente that a blus whould bo otruak in noutral modium with the ferrous oulphate addition slightily ahead of tho forrocyanide at all tines. I teaperature of $25^{\circ}-30^{\circ} \mathrm{C}$ with the soove procedure produced an almost non-branze blue of high tinting strongth wi modiun softnese. ( Trbl• IX )

Fydrogen Ion Comcentration.

The formation of the imiormediate whit pesto we corried rut at various hydrogen ion oncentratione, At vory low pif wilues the poste wes more geintinous and and colored, while formation at a pH of 5.5 producod a gramular pasto which gettled rapidiy and wat neariy wate.

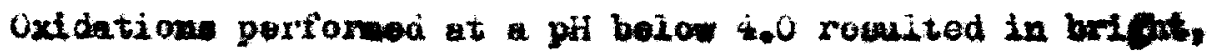
soft, brilliant blues which were rether bronsy. Then the 


\section{WBLIX}

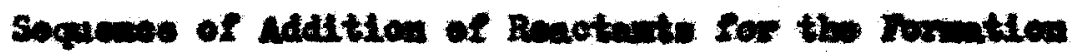
of the Intermodicte Parte.

\begin{tabular}{|c|c|c|c|c|}
\hline amplet & 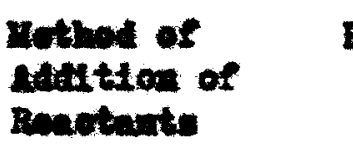 & Brome & Nongth & 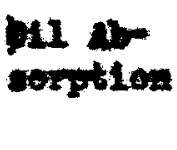 \\
\hline $2 *$ & 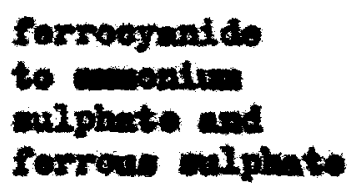 & entet & 0.85 & 18 \\
\hline $\mathbf{J}$ & 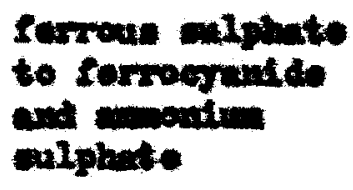 & breme & 1.00 & 20 \\
\hline $\mathbf{I I}$ & $\begin{array}{l}\text { montral axi- } \\
\ln \end{array}$ & $\begin{array}{l}\text { nare broase } \\
\text { the } J I\end{array}$ & 2.15 & 17 \\
\hline $\operatorname{III}$ & nenturel modin & bramo & 1.05 & $\mathbf{2 0}$ \\
\hline
\end{tabular}

* Timpotare hold at $\mathrm{Bg}^{\circ} \mathrm{C}$. 
pll of caldation we 5 the plgnont was found to bo vary

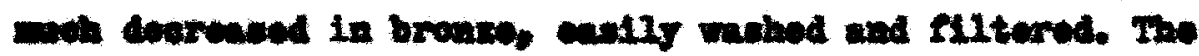

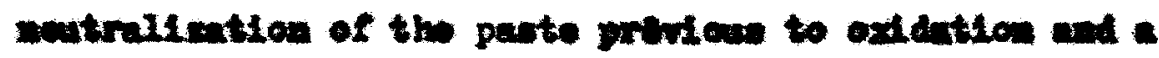
mbeoquant exdidtion at a pil of 7 romelted in a product will could not be filterod. ( malo $x$ )

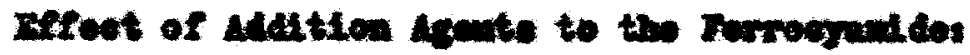

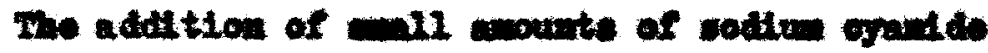

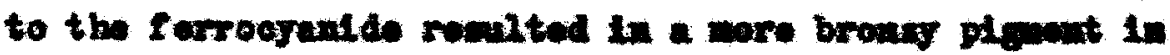

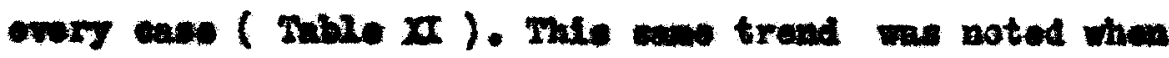

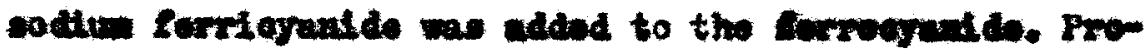

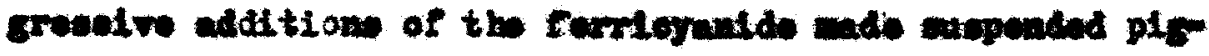

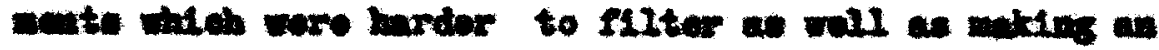

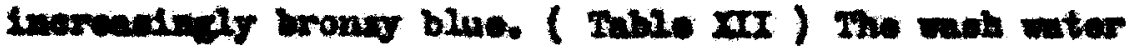

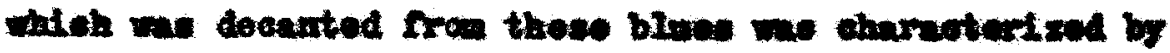

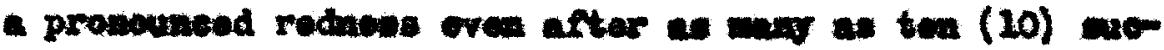

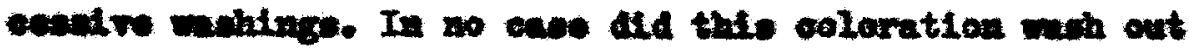
complotely. The eddition of mall moonte of forrioguide ( 0.025 moler) showed only fulnt traces of this poloration

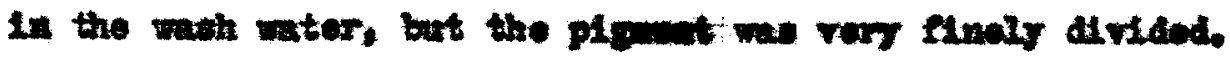
The aldition of $0.1 \%$ of potactive alien to the ferrogyande we found to ant a color intenalfier and 
TMat $\mathbf{x}$

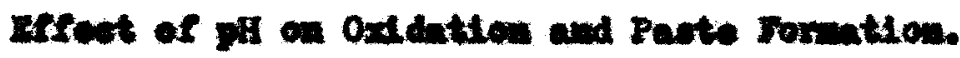

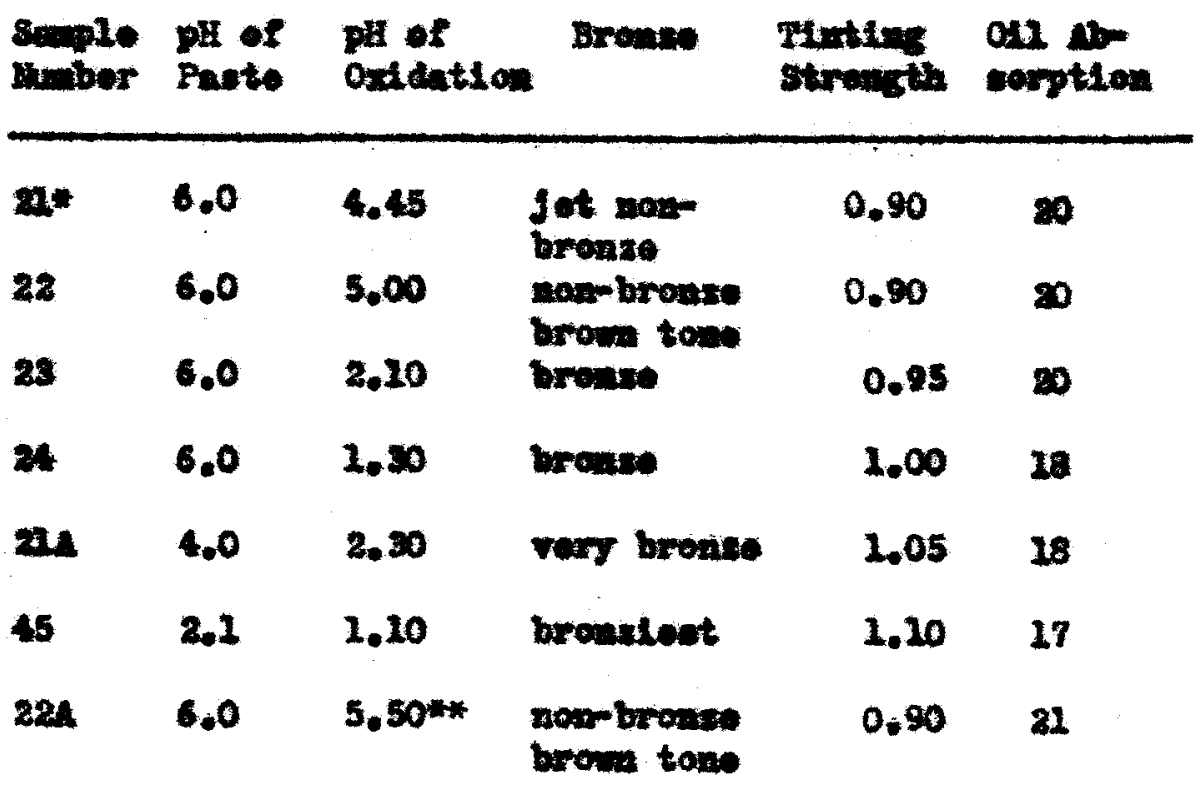

- Temperatare hald at $25^{\circ}-30^{\circ} \mathrm{C}$.

* Hor eded puler to digontion with on wo 5.5 
Taxu $\mathbf{x}$

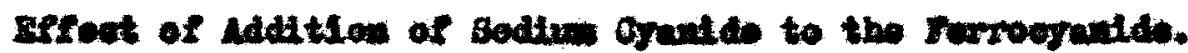

\begin{tabular}{|c|c|c|c|c|c|}
\hline smplo & vola & Droint & Anting & al ab & haxt \\
\hline $\operatorname{ADSB}$ & 0.025 & monts & 1.05 & 28 & $\cos$ \\
\hline 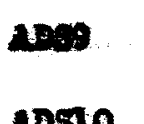 & 0.005 & $\begin{array}{l}\text { Lees than } \\
\text { ADs8 }\end{array}$ & 2.00 & 19 & ent \\
\hline
\end{tabular}

Timporature bold at 30.0.

TABW 2T

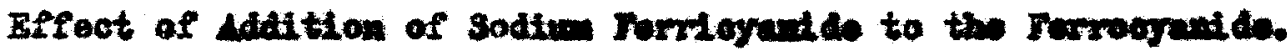

\begin{tabular}{|c|c|c|c|c|c|}
\hline $8+2$ & $\frac{\mathrm{rol}}{\mathrm{rag} D(\mathrm{ax})_{6}}$ & 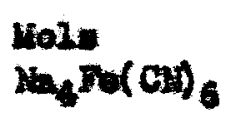 & Brome & ating & as no \\
\hline Anst* & 0.50 & 0.50 & $\begin{array}{l}\text { wore broane } \\
\text { than A7s2 }\end{array}$ & 1.10 & 18 \\
\hline $\cos$ & 0.25 & 0.75 & leost bronse & 1.15 & 18 \\
\hline inss & 0.75 & 0.25 & $\begin{array}{l}\text { nore brome } \\
\text { than ADSe }\end{array}$ & 1.10 & 17 \\
\hline Anst & 1.00 & 3.00 & bronuter & 0.85 & 15 \\
\hline
\end{tabular}

- Teperatare bela at $60^{\circ} \mathrm{C}$. 


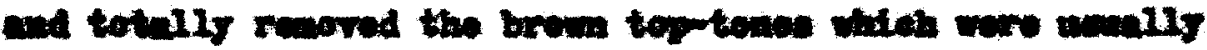

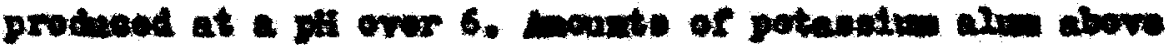

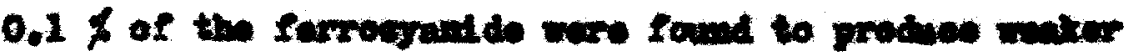
colore mat lacked brillanor.

X-Bor Inwetertions

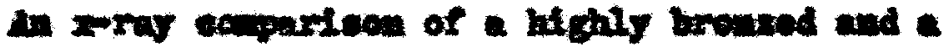

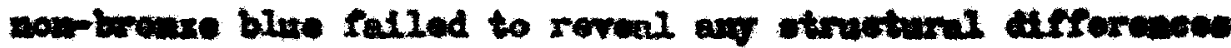

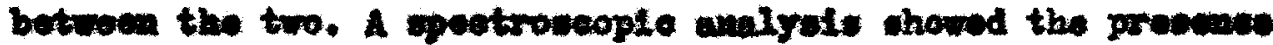

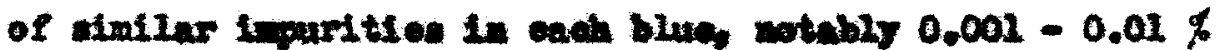
11, $0.001-0.01 \times 1 \mathrm{~m}_{0}$ and $0.001-0.2 \times 6 \%$

Yothod of Drying:

Plenoute mioh wore dried in anen bowe $70^{\circ} \mathrm{C}$ 11 honod ugly red ounte. Thor wore bard to find and a

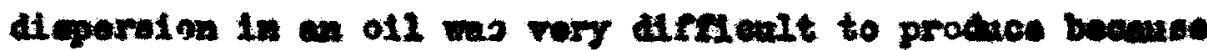

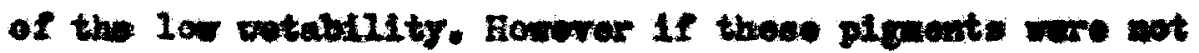

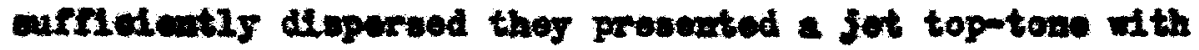

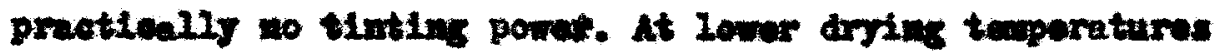

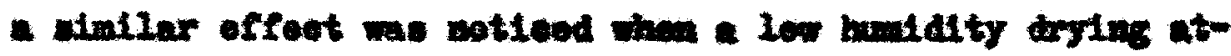
nowphore was enplored. Pigmente if th the mont isolroble proportles wore obtalued won dried at $65^{\circ} \mathrm{C}$ in an atwaphoro

- Private ecmuteation frow the Bow Gondeal Co.s Millond, Mohigan. 
Ath a relative maldity of 50 f of ebove. The remite of vartons drying teporatures are show in Takle IIII.

Inemarle Touses:

The iscanto forme of the forrogyaldes were propurad by the nothod of Brivo (20) and the $\alpha$ and $\beta$ formo coparatuly mado into plevoute undor similar com Ations. Thor wo approciable vartation in the degen

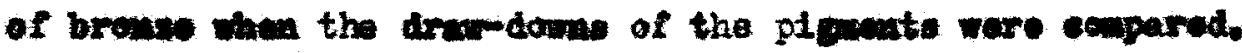

Particle sizas

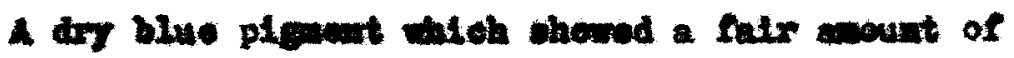
broase we shuken with othyl acetete for thirty mimates in a epazetory funad and then allowed to sottle. Porlodically

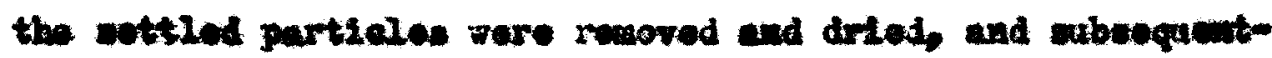
17 nubbed up in blown castor 211. The slower settling fract-

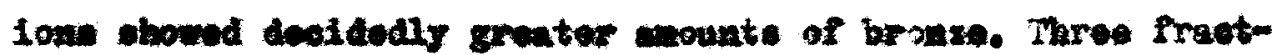
Low are shom in Flgure 6. The timos of gattling wore in the ratlo of 1 to 22 to 43 . The tinting strongth of the pigrout vanted droetly whth the broase. (Tuble XV)

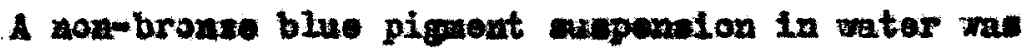
refluxed for varying langthe of timo. Ifight (8) hours we cucrieleat to produce appreclable peptication whieh prom 
TABA III

atroet of Bylus on the Bromalns of the Blwe.

\begin{tabular}{|c|c|c|c|c|c|}
\hline 8 & Drying & $\begin{array}{l}\text { Ralattro } \\
\text { nuditity }\end{array}$ & Brenee & $\begin{array}{l}\text { Futh } \\
\text { strength }\end{array}$ & ota 10 \\
\hline LB & 105 & orou & jet & 0.75 & 20 \\
\hline 4 & 85 & oner & altht & 0.86 & 24 \\
\hline 10 & 70 & $\mathbf{8 0}$ & Wroitas & 0.90 & 23 \\
\hline 18 & 100 & 50 & fet & 0.80 & 26 \\
\hline $\mathbf{L B}$ & 65 & 50 & eltot & 1.00 & 20 \\
\hline LB & 50 & 10 & brome & 1.05 & 19 \\
\hline
\end{tabular}

Puns XV

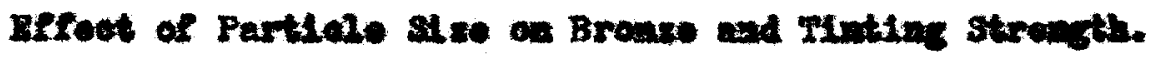

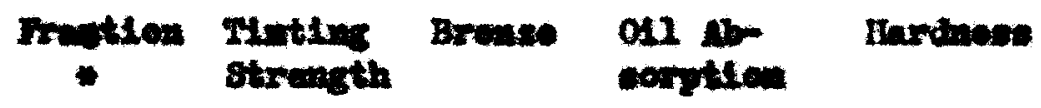

\begin{tabular}{|c|c|c|c|}
\hline $\begin{array}{l}\text { futtedt } \\
\text { ortaling }\end{array}$ & 0.95 & browne & eort \\
\hline $\begin{array}{l}\text { nodivg } \\
\text { furt ottlo } \\
\text { ins }\end{array}$ & 1.00 & $\begin{array}{l}\text { nore than } 19 \\
\text { abowe }\end{array}$ & soft \\
\hline $\begin{array}{l}\text { lowent } \\
\text { opttilng }\end{array}$ & 1.00 & $\begin{array}{l}\text { nore thun } 18 \\
\text { middle fraot } \\
\text { ion }\end{array}$ & rary eaft \\
\hline $\begin{array}{l}\text { rouldet on } \\
\text { expaxtion }\end{array}$ & 0.80 & broantest 16 & rery sort \\
\hline
\end{tabular}




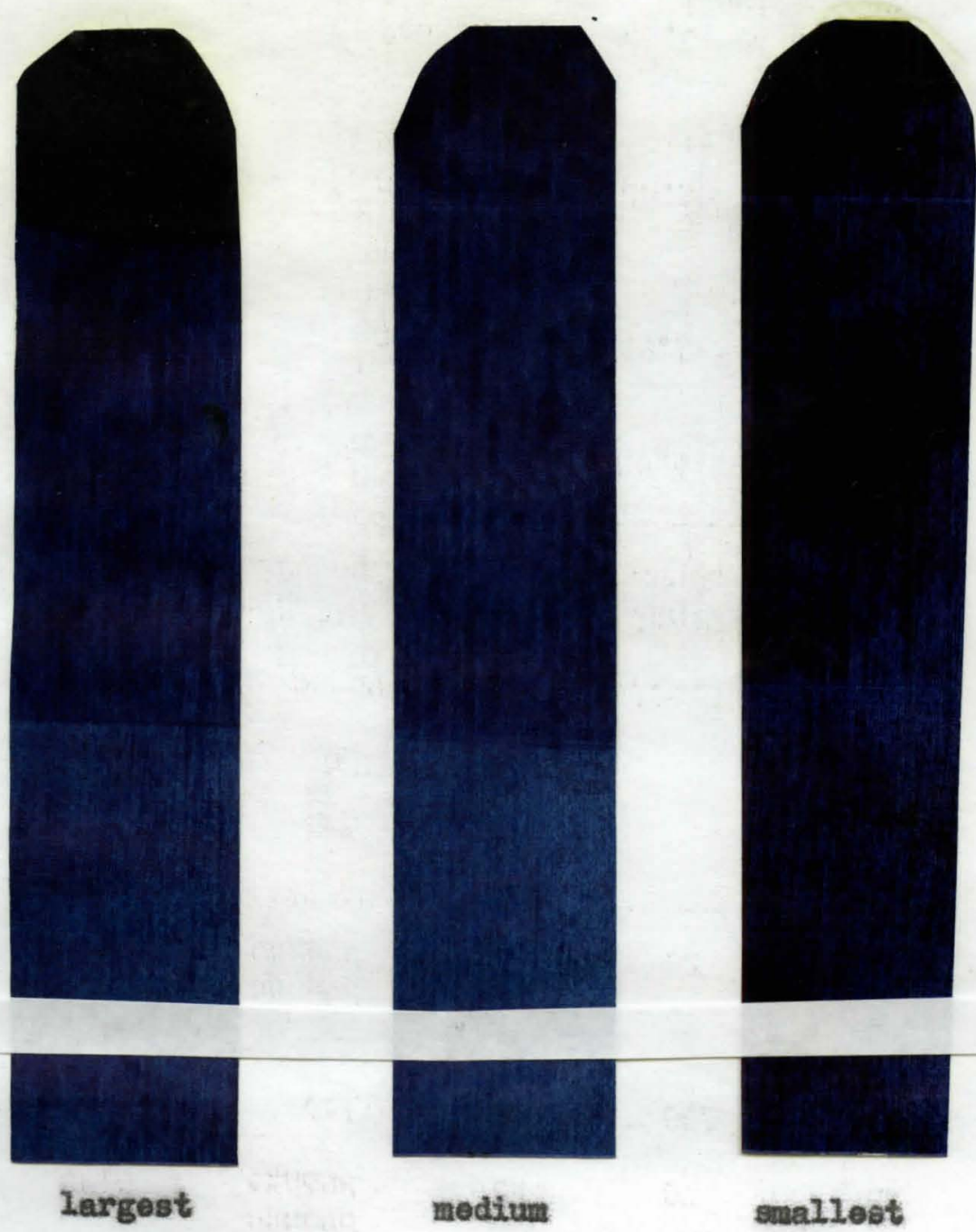

Higure 6. Effect of Particle Size on Bronze in Blown Cestor 0i1. 
goned to comploblon and the bronse tint of the material inorwed proportionately. At the point of ounplete pep-

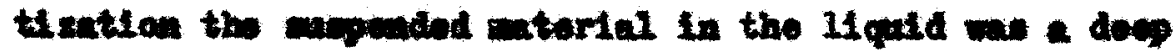

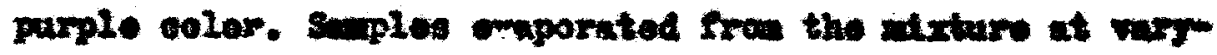

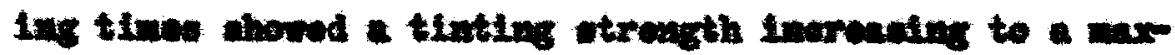

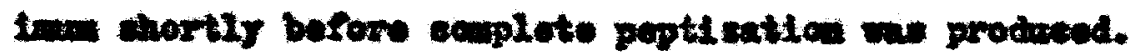

( Imbiex $x$ )

\section{Experden routales}

It wa found that verlowe pignont vehiales ansod

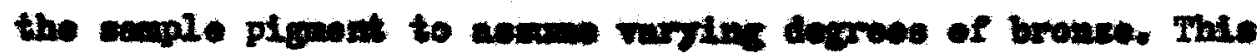

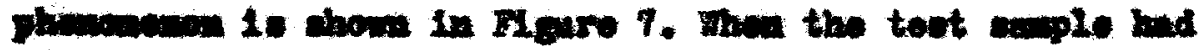
drich, a this oont of elear leoguer applled to the murfoce deerosed the browes. (Naxe 8 )

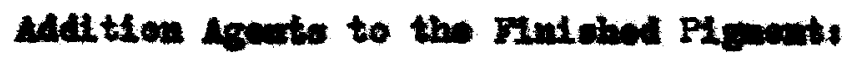

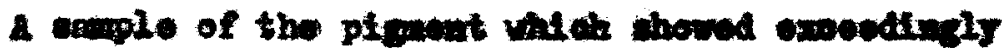

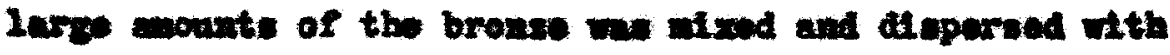
various types of bleek plenouts and the rosult botod on

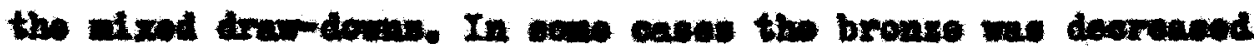
untsi it wae not peroptible, rot the solor of the waxd pignent ottll appeared bluo. of all the additive black wich wore trled, Irory Black was fowed to be the woot 
VABIS XV

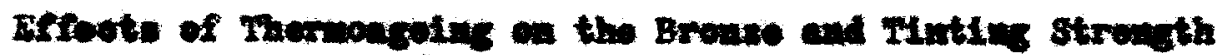
a a stowain.

\begin{tabular}{|c|c|c|c|c|}
\hline $\begin{array}{l}\text { Alm of } \\
\text { Ratint in } \\
\text { Hotro }\end{array}$ & Drente & Lntring & $\begin{array}{l}\text { a. A } \\
\text { arption }\end{array}$ & Enxtinowe \\
\hline 0.0 & wodtu bronte & 2,00 & 0 & nodiu \\
\hline 0.5 & mediu bronse & 1.05 & 29 & $\begin{array}{l}\text { wodiu } \\
\text { hard }\end{array}$ \\
\hline 1.5 & browe & 1.10 & $\infty$ & eort \\
\hline 40 & Lnorwanth & 2.10 & 20 & eert \\
\hline 6.0 & rory bususe & 0.95 & 19 & vory oort \\
\hline $8.0 *$ & mowt bromas & 0.80 & 16 & very east \\
\hline
\end{tabular}

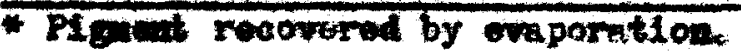




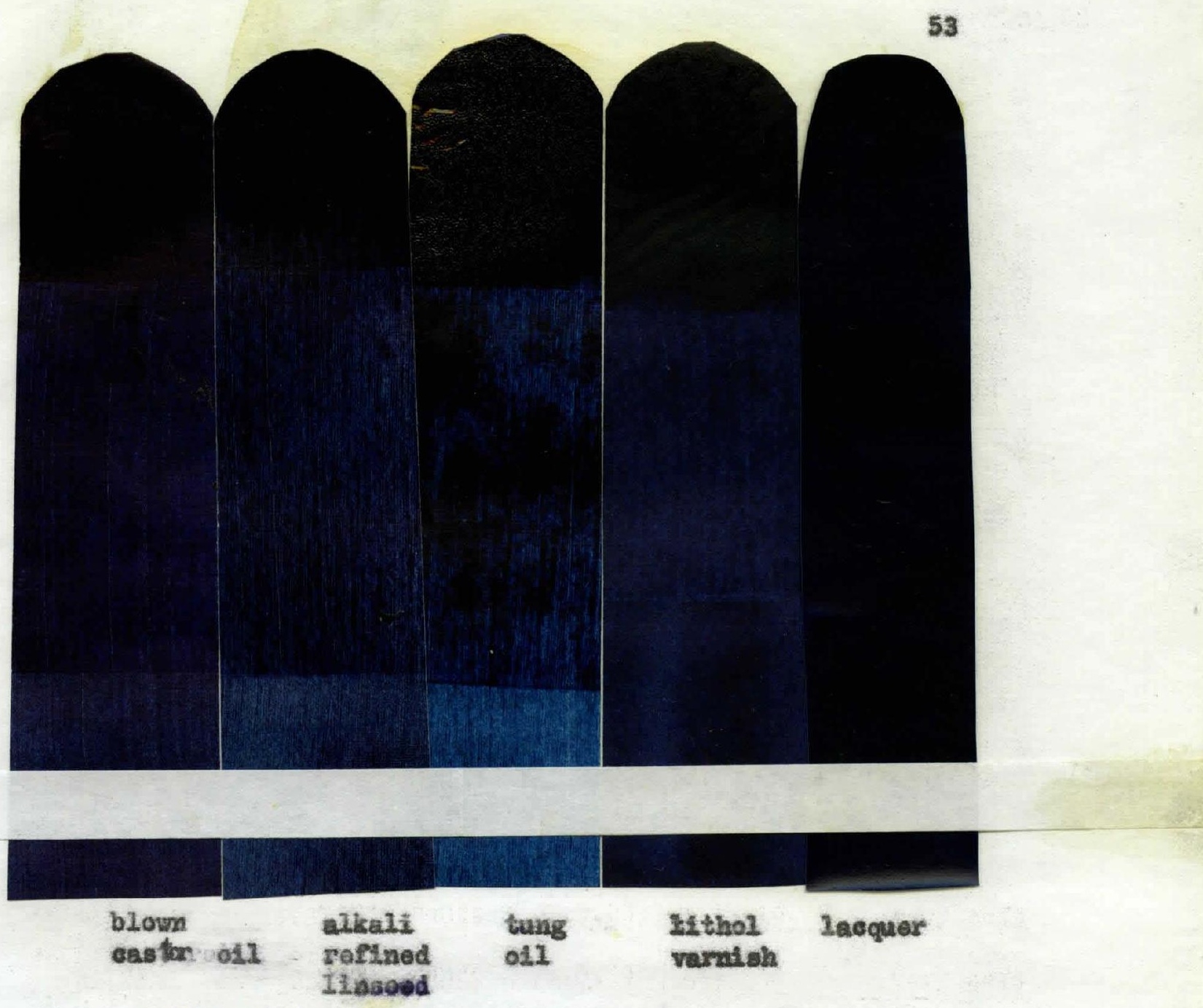

Figure 7. Bffect of Pigment Vehicle on the Bronze. 


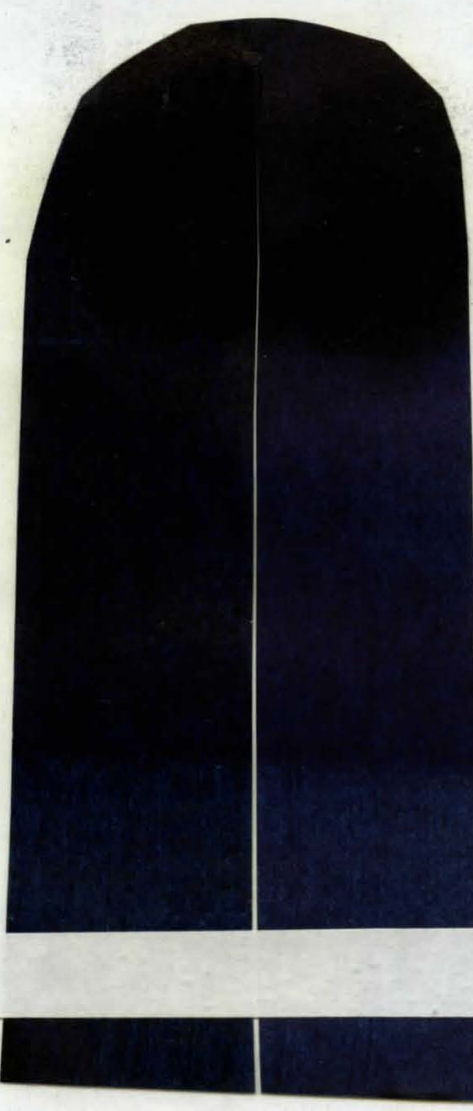

coated uneonted blowa tastor oil.
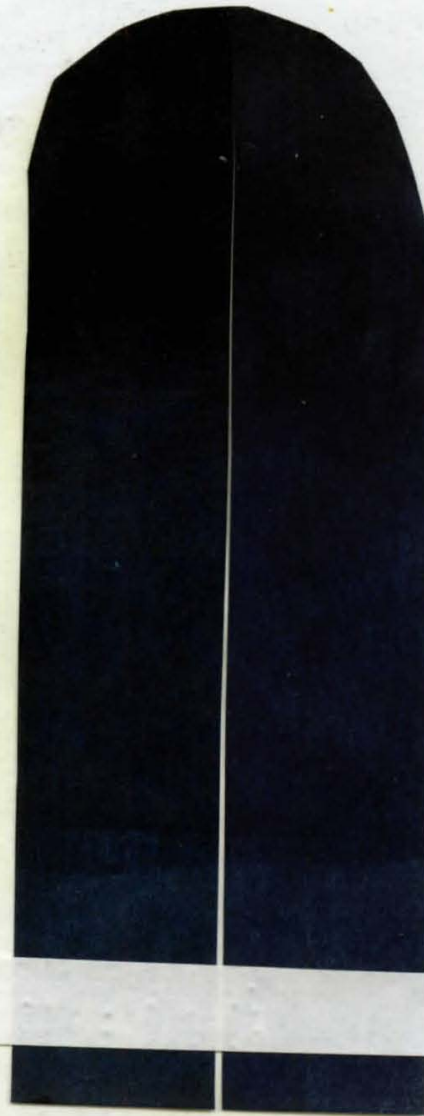

costied uncoutad 11thol varaish.

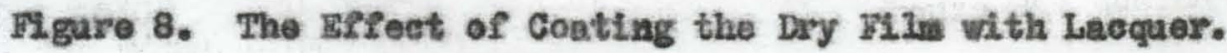


gutteble alle Garbon Blect romelted in rod-brom tinte.

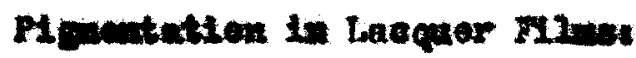

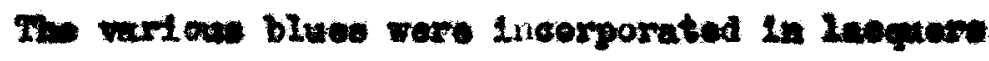

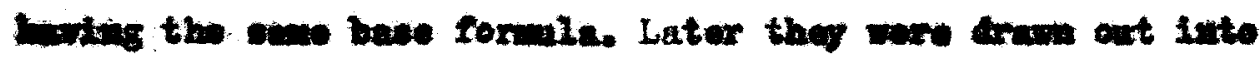

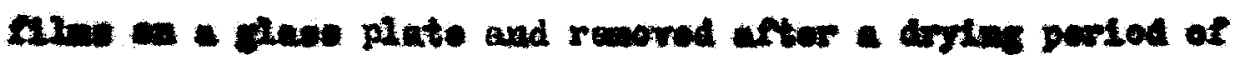

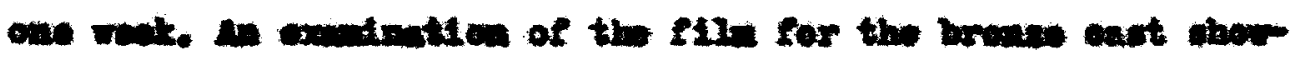
A It: provence when both the top ani wodoralle of the film

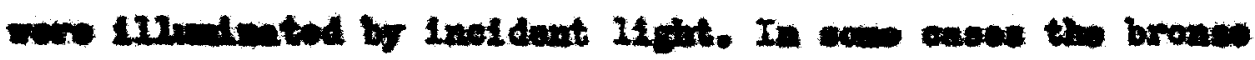

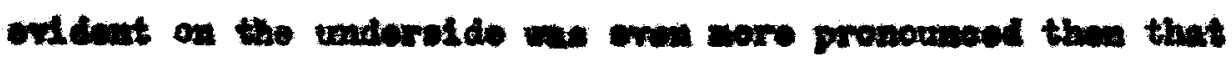

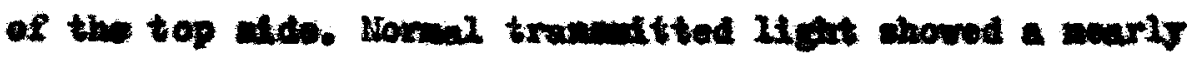

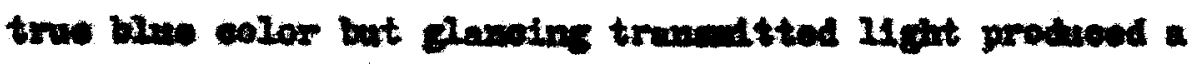
nowr purpls Ihude.( Figure 9)

arraltaneors 1meorporation of blecke in tho bles

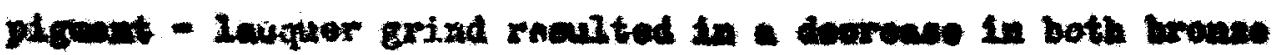
and total inaident zerlooted light. Tho affeot on trunmitted Lent mo dindiar. 
top alde

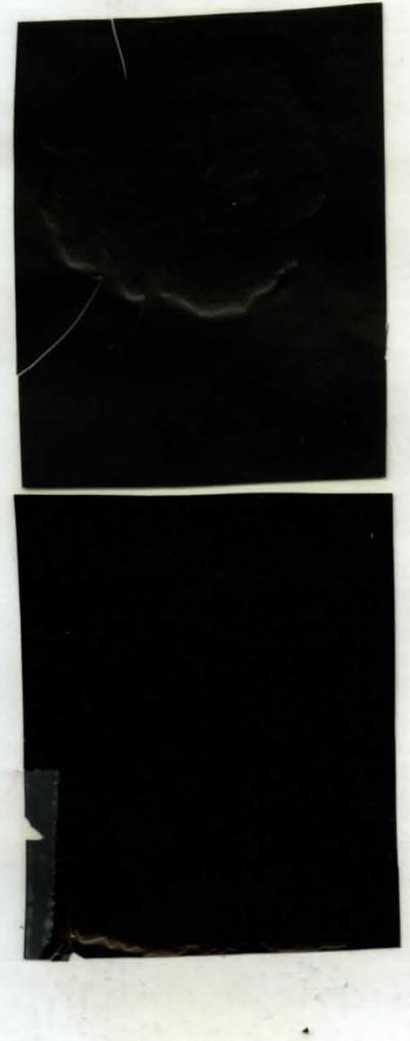

bottow side top side

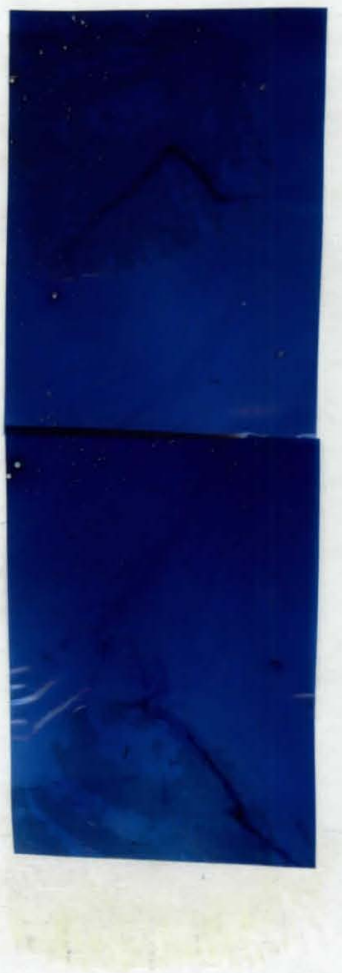

bottons side

Mgure 9. Plgneited Laequer LIIns. 


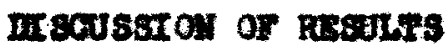


A toudy of the remalte roperted if the provien

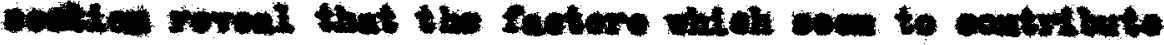

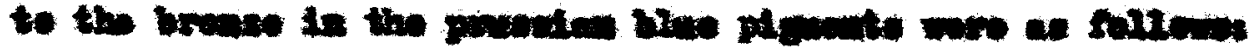

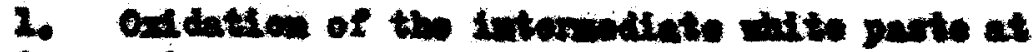
whe teportures. vinus.

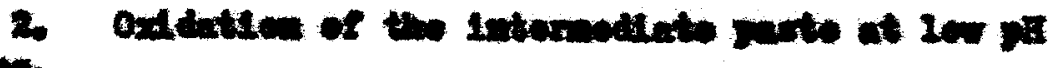

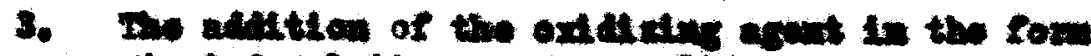

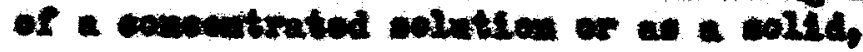

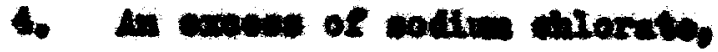

5. The we of etrome oxdaline agmb,

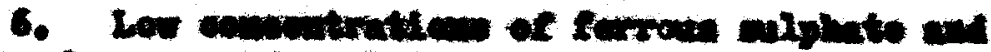

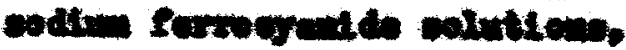

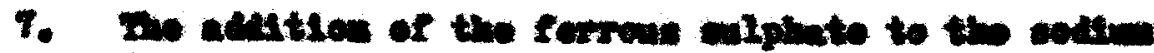
Sorweractes,

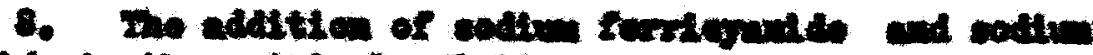

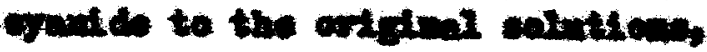

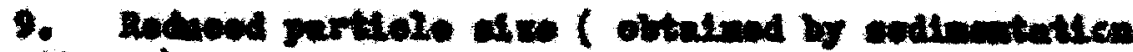
sopuratiled I.

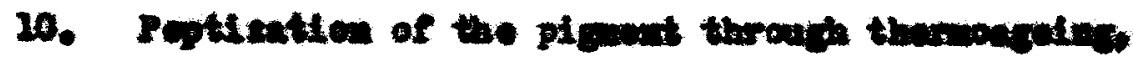

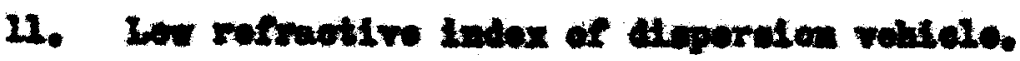

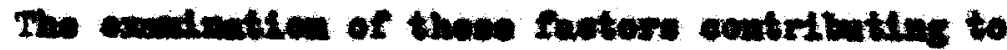

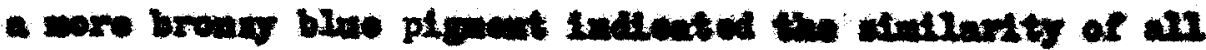

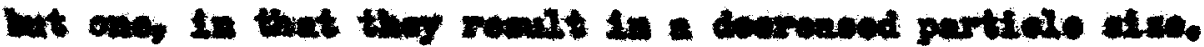

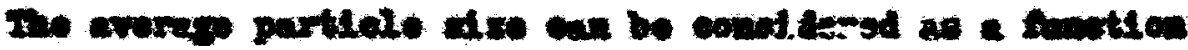




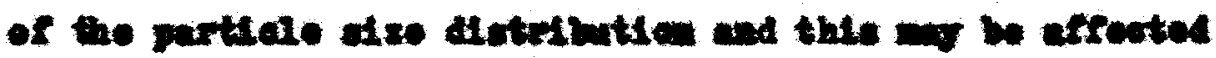

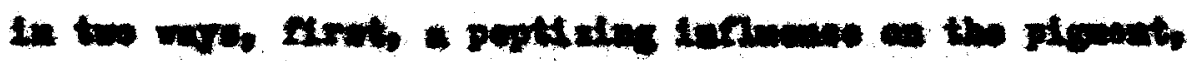

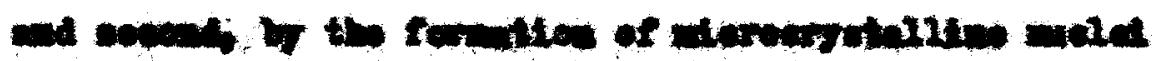

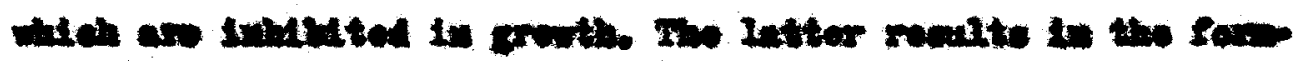

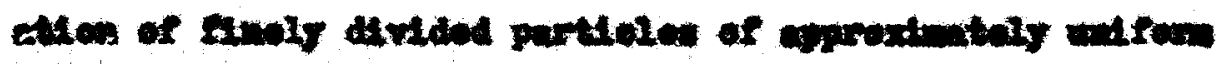

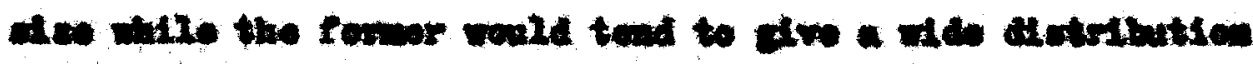

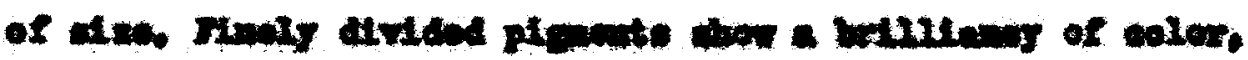

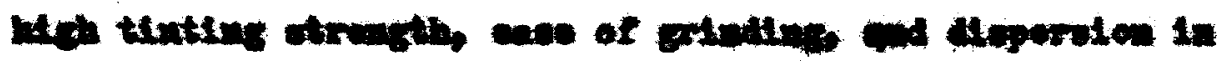
a11.

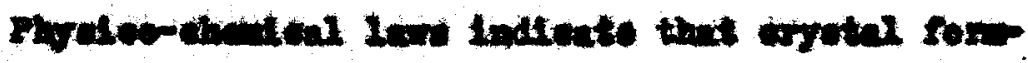

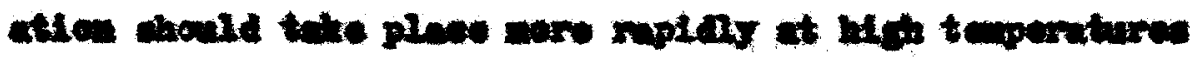

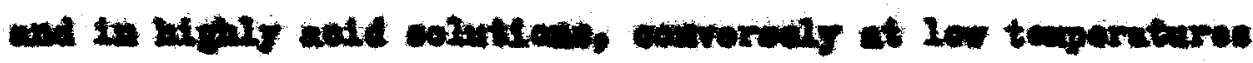

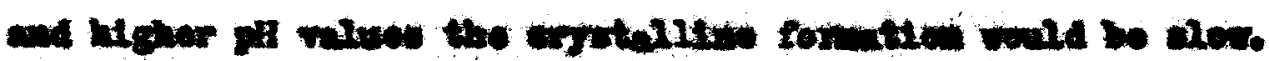

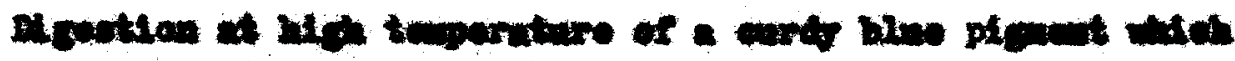

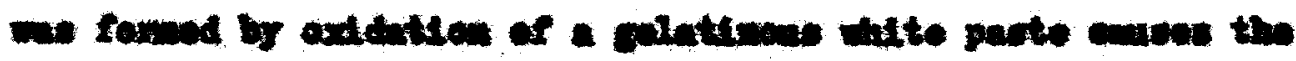

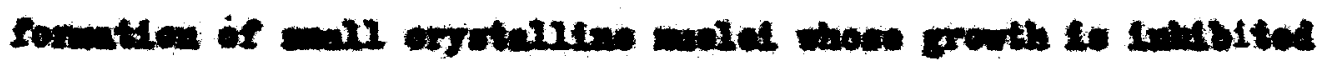

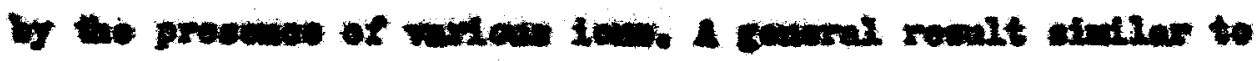
the the bew roportiod by nooller (50).

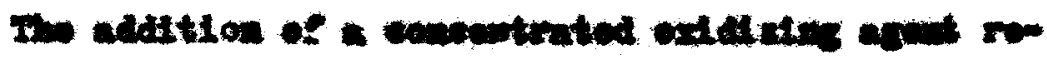

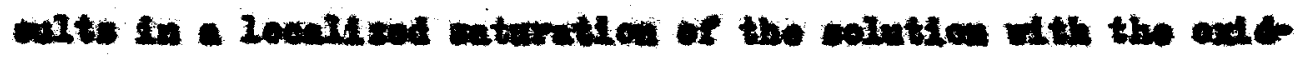

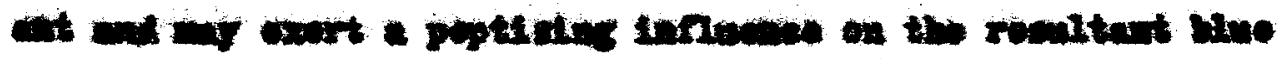

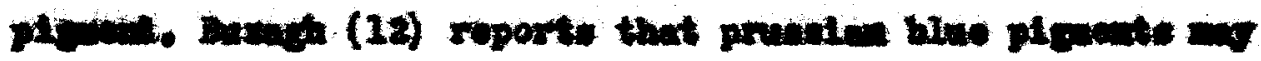




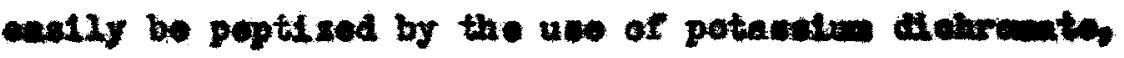
and wo hare wo reapen to belleve that thele is the enly

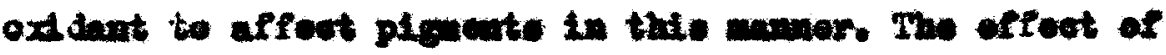
nogatirely ohurged iown on the eocalation of pruaden bles has bem roported by oloosh and buler (62), wow findinge are in acoord wth those above.

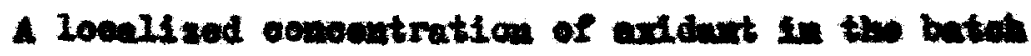

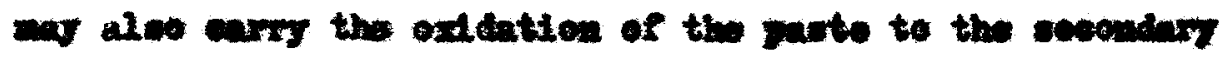
otage, that is, oxdidition of the forro- to the rorriegraxide.

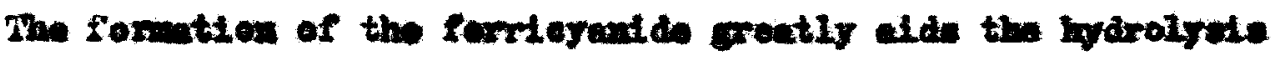
of the forrieforroognuld with the formation of the atabiliadre

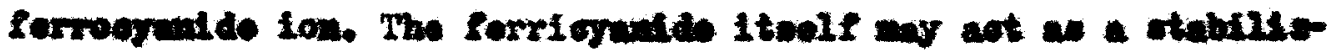
ing len fer the prusolen blwo ool. Thte is in agroment with

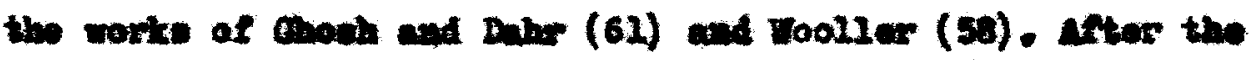

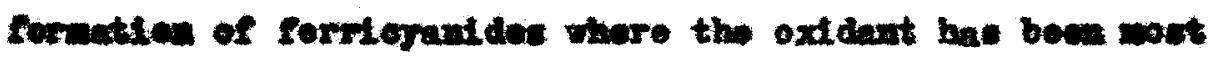

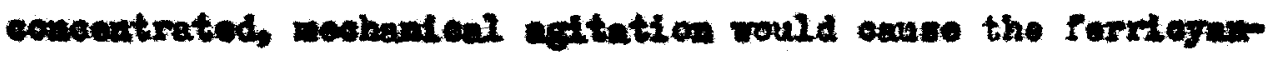

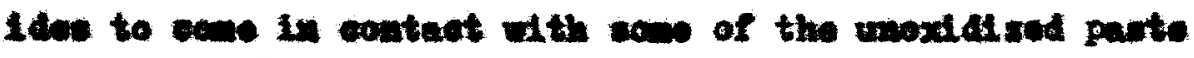

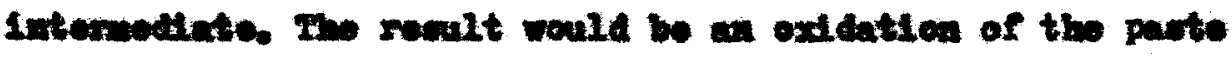
to prusctan bles and the reduotion of the forrtegunide to

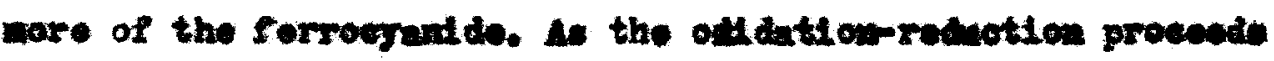

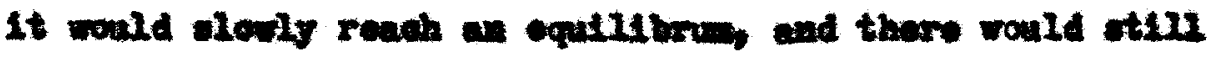

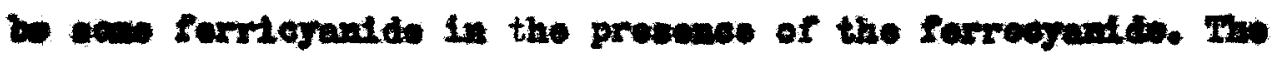




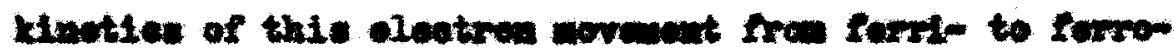

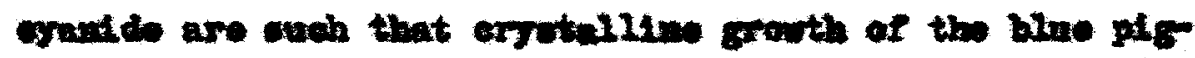

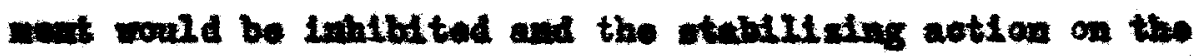
eollotd would realt in a finoly dirdad plonot. The Identifieation of ferriesande in the find blue is iffenelt for a muber of reavens. The erytal otructare of both ferro and forriegrumide are aidiar and the xeray ho been unable to produce a mouns of dotento son of one in the prosence of the otber. Ohation wothede

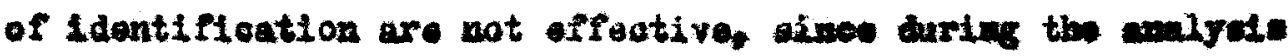

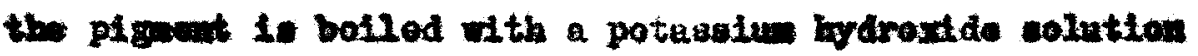

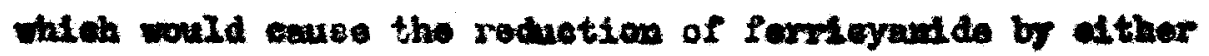

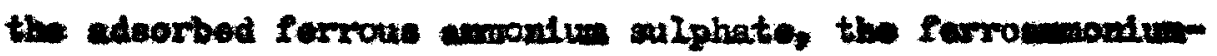
ferregnule ar both. This wakes the ldowtifloution of rery mall amounte of forrioyenide irprobuble undw thoce condtlows.

The prepence of cerrtorenide and ovande wore atudied

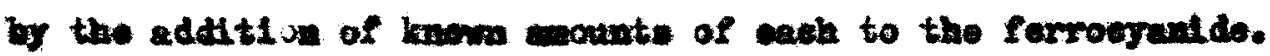
Thi: added to the evidence for the conept of peptisation and

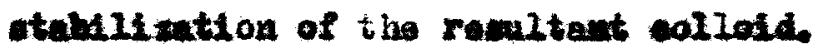

The presenee of axsens coditu hlorate and othor

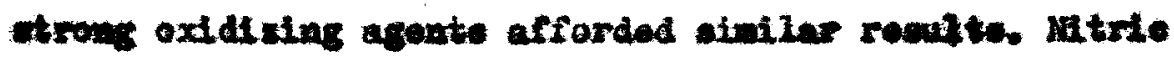




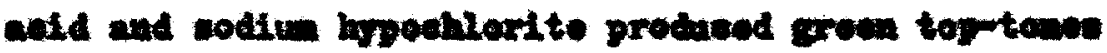

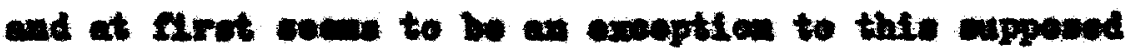

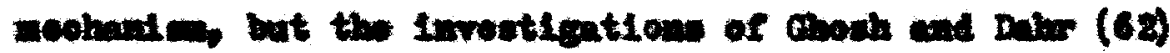

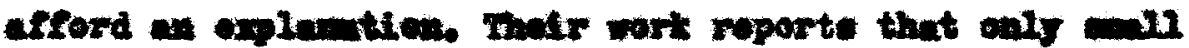

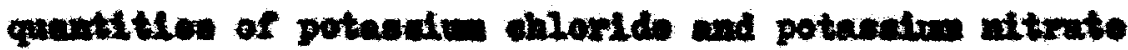

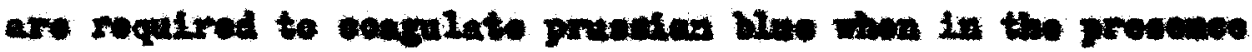

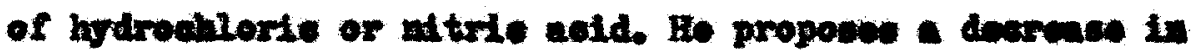

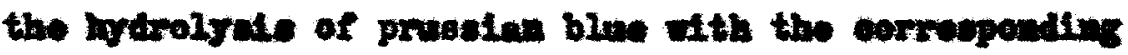

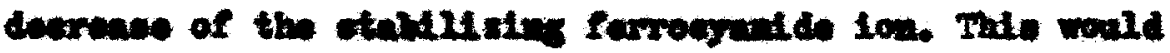

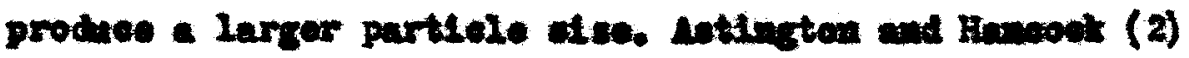

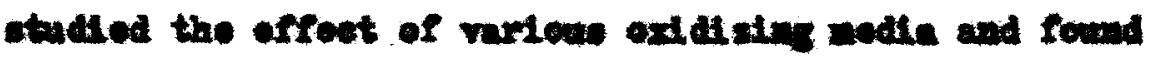

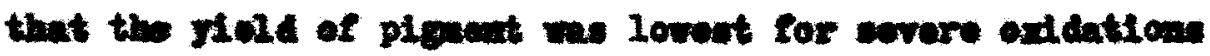
Wth potendu ohorate in acid aolution whe that oxte

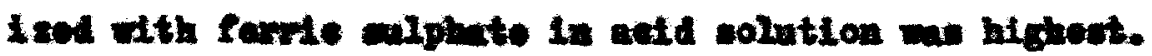

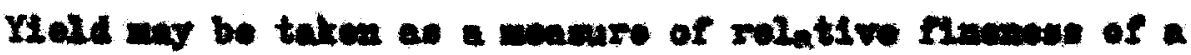

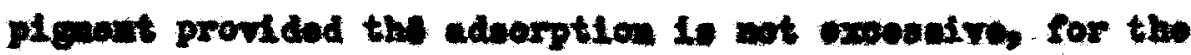

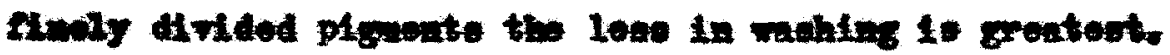
The formation of the plgnet in alute colntion

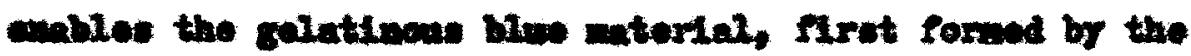
oxdation of the internodicto purte, to rearrume itenif

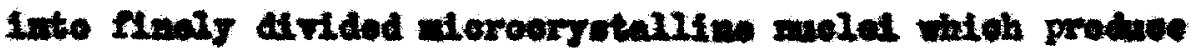

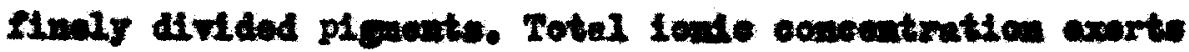


a narked effeot on the gromth of the prasedan blue partiele after oxidatien as wil an the proedpitution

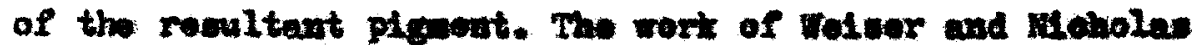
(54) Infors the formation of Rmoly divided piguonte in

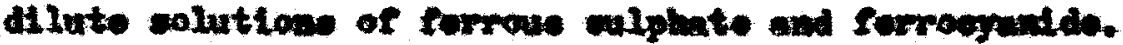
The rort of Jookt and singh (23) Indleates that

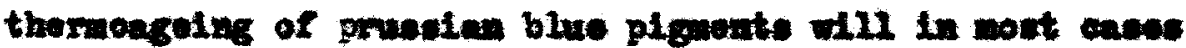
produes an increase in the Viecosty of the ofl-phosent

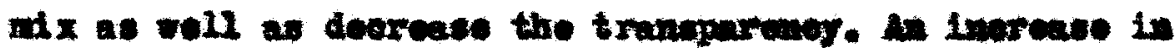

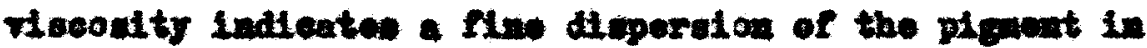
the ofl wile a deeronge in trengpareng showe greater tift-

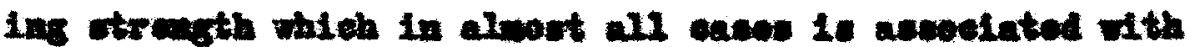
mall partide Ase.

The addittion of the forrogratid to the forrene culphote coluthos rocults in a wite pate dateh prodneos a coaros grained pignent, but if the forroue wiphate is

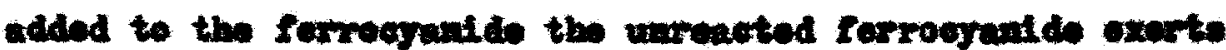

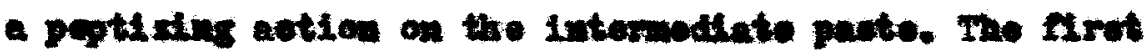

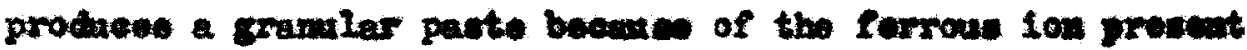
during the eatire formation portod bat the latter realte only in eongulation after thare is an exwes of forrous axlphate. This coagniation it not so ecaplete an in the flivet 
eave, and a andler average partlele dro fil malt. The average partiele atse of a prueden blus akes it imposible to we the ateroseope for a partide alze deternination and the salinembetion mothod of Kelly (27) Is aleo opea to question. Objectione to the lattor are die to the length of the of eottling of the pignont and the orror tutroduced bs emporation over thic porlod. The mothod of ettline bowerer, affords a qualltatlwo

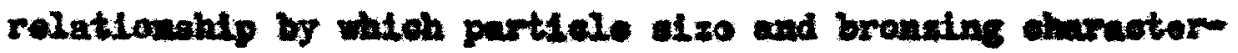

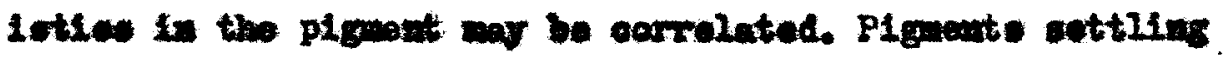
at afferent mater would eontati a different avare partide sise and wore roadily camarod for brones and tinting otrongth. It will be notod that these rovalte axport the parklele Awerouns ralutionaip.

Dring of pruetian blue mar be conaldored as a procens of remown of water botween tho phenm partales and the reantant agriomoration or crouplng of thewe part-

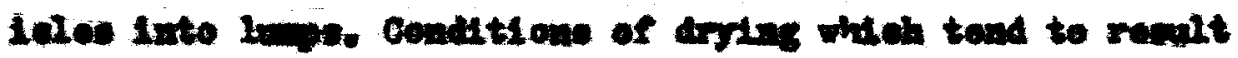

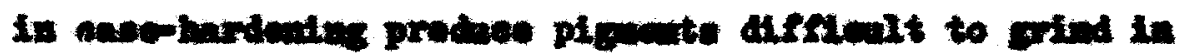

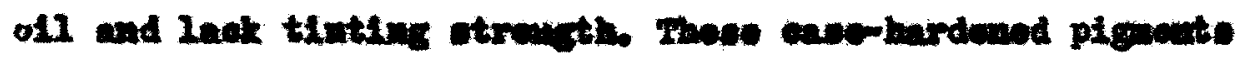

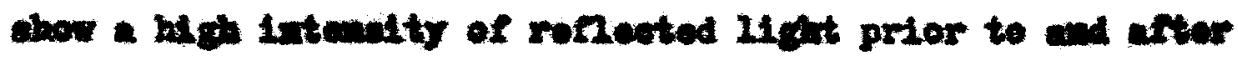




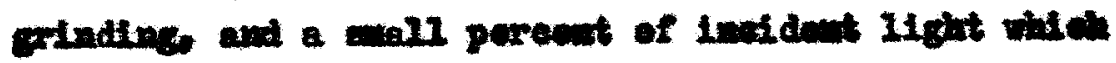

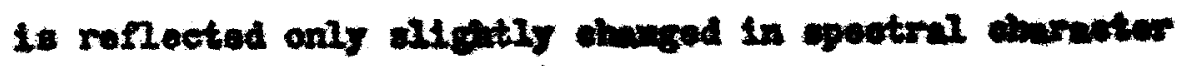

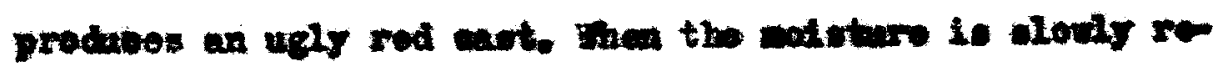

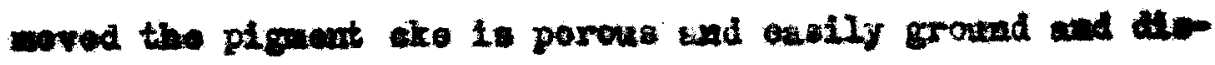
poraed in ail. The Inatiant Ilght ia able to ponetrate depply tute thil type of ploment ariace and as a roult very 4 tilo light is refloctod. This pignont appente rteh blus.

The relationsilp betreen partiele we and brom

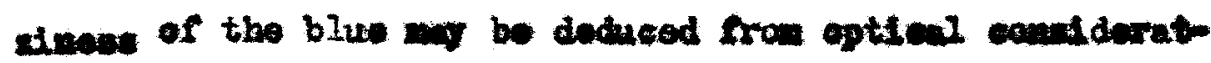

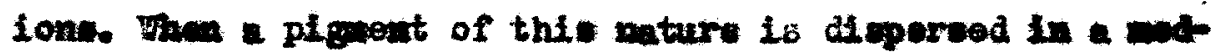
Iu It is cosentially a collatial grotem and wil follow

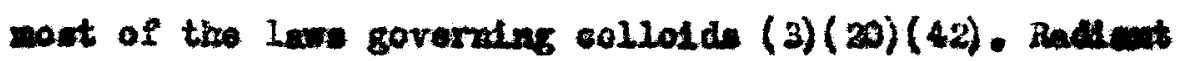

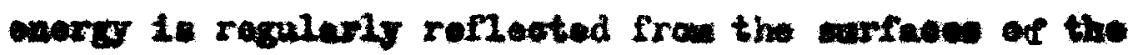

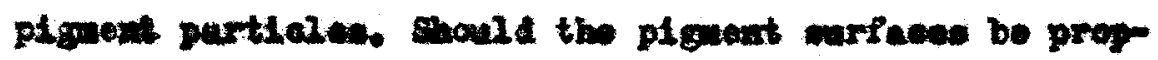

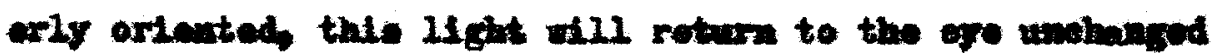

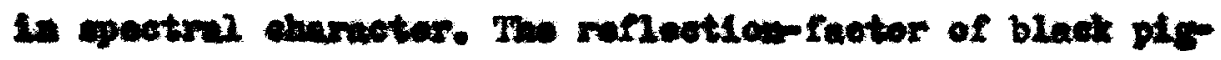

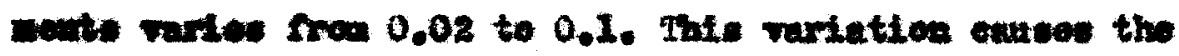

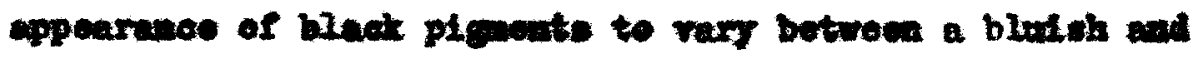
a rad towe. (35)

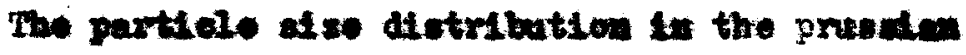


blue cover a ulde range botweon thoes elowe to walemaler

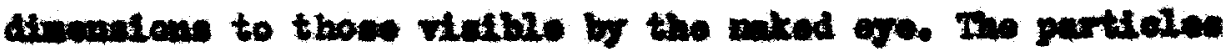

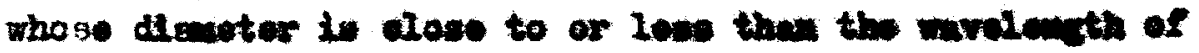

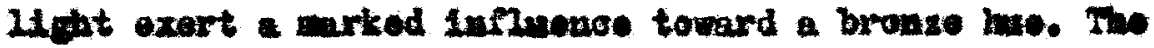
wave frout of ligh seattered by an oufect whioh is wille.

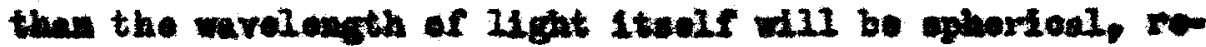

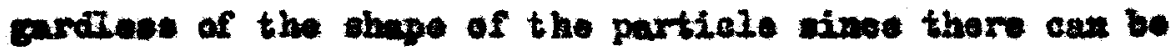

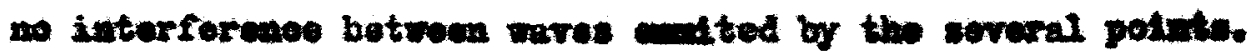

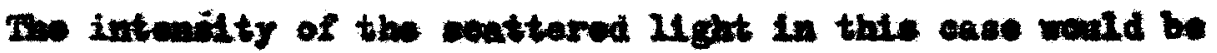
proportional to the reatproal of the mavelungle rulued to the lourth poror (29) . 1.4.

$$
I=\frac{1}{L^{4}} \text { ( Daploden Bquation) }
$$

where I If the intenalty of the reattered 11 ght.

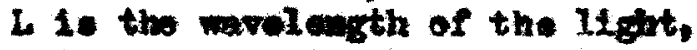

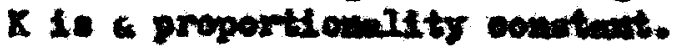

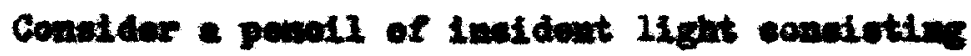

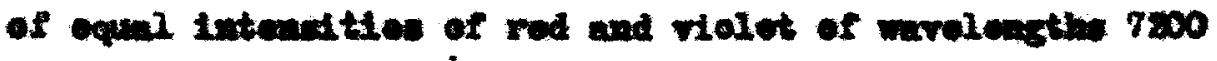

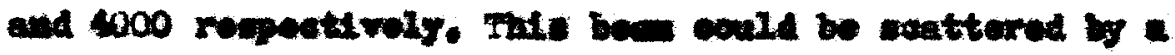

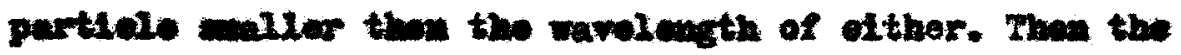

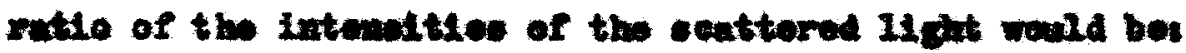

$$
I_{x}=\frac{x \frac{1}{(7200)^{4}}}{x \frac{1}{(1000)^{5}}}=\frac{1}{10}
$$

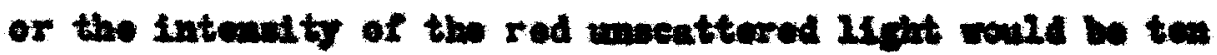


tines that of the rolot fros a partielo maller then the wreleagth of efther, and the groter will appear to have a rod cast.

Inekicah (35) rofors to the relationohip botmom pigents and thatr vabiolon an follower

- Host volulelos when dried have rofractive indlees in the nighbortiood of 1.5 and thil Indieates that the amount of $11 \mathrm{ghat}$ rogularly ronected frow the mooth ourfaee the vehicio is about 4 percout. A abutanes to be most offoctive as a pigent should have a high rofreetive index for the bue it nout froo15 irenmite. The refreetive index varias conalderably in the velghborhood of an adsorption baid, being groator on the lonerwave alde than on the whort-wave alde. This is the reanon for the greator rofraetive indiees umally exhlbited by jellow, orenge, and rod pignout. than by blue and riolot. If the refrective index of a piguent elonely mateboe that of the vohiele, the formox wil diffues very littlo light. sueh a plement rould ordinarily be wixed with ono of highor rofruotive index whieh wll diffues the 1ight."

This would indiente that for a perity of color the graine ahould be walforn, and that thare should be no eoleotive

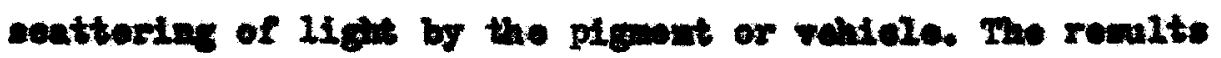
of thlo invortigntion bar cat this prinodplo by todieatIng a change in the bronse tome of a pigmont depondent upon botk the average partiele aise and the voliclo cuployed. Highor refraetive indiece produced lowest apparent bronzo. 
In wry eaves the degres of brouse of a plenent

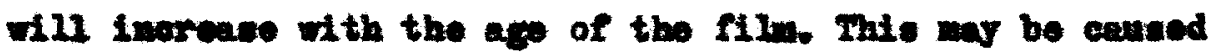

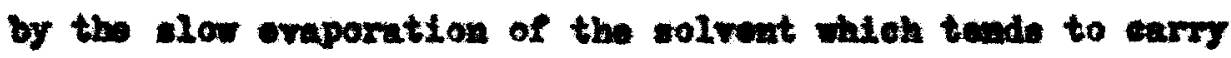
the abmatiacosic partiales to the ourface of the fil where thay becom nore effectire in seattering the light.

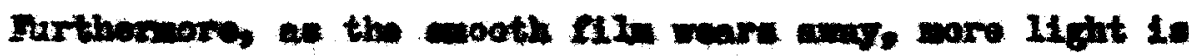

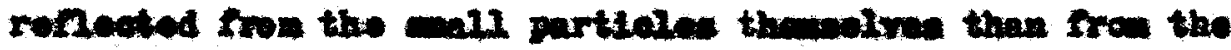

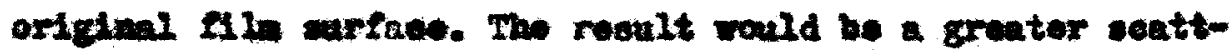

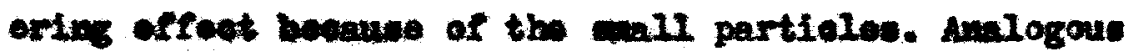
phencanona have boon wotod by Bancroft (3) in the otudy of uturel plomontation.

Eromination of the factore affecting the tintiog

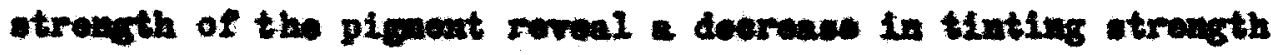
as rollowas

1. Smontun oulphate in exeess to 1.5 mole per mol of codium formograntes.

2. Prosuse of adeorption products or adulxture of decampontion products in the perte.

3. Lmoutu alphate lower than $0.5 \mathrm{~mol}$ per mol of nodiva Sermocyante.

4. Coare partiele sise,

5. Collotela partiele sze.

These fuotore way be grouped an bringlig abost the 
deerease in tinting strength in three ways

1. by the adeorption or adulyure of a natorial which ecte as aluout in the pigmeat,

2. by a viriation in nolceviar conatitution produced by chenteal eoustitucute.

3. by the lack of proper dieperation of the pigaent In the viliele.

During the romation of the internedinte vatto parte and tharwafter the phwamom of adrorption and of

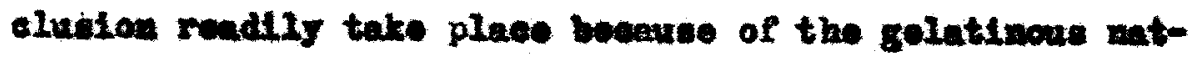
ure of tho material. A quantity of all the atoriale prow ent in the arrounding 11 quore will tharefore be preasut

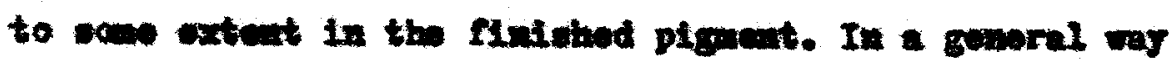
It wan be rtated that aloorption wil bo prestert for mat-

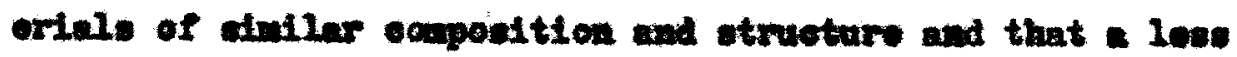
colwble naterlal all be aborted to a largor oxtent thas a wo coluhl material. Factore mok as teuporature of prochpltation, temporature of digention, anount of dintion.

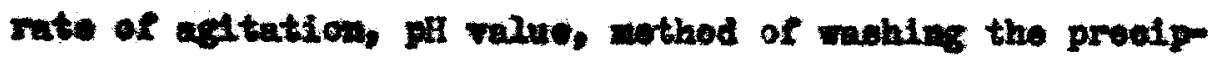
Itate rate of adition of rumentes and the wount of rom

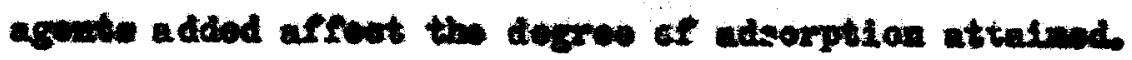




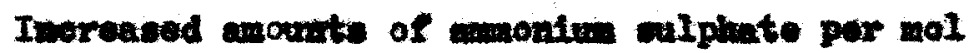

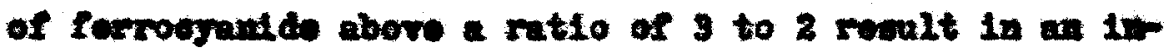

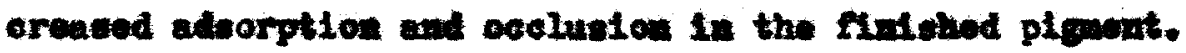
The ourve ( Flgure 3 ) are inditeative of adsorption siwe

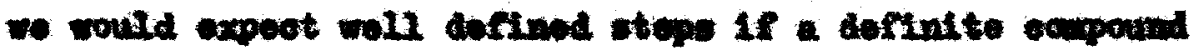

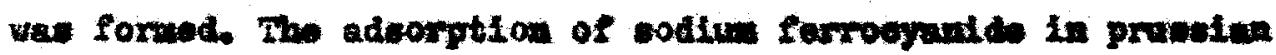

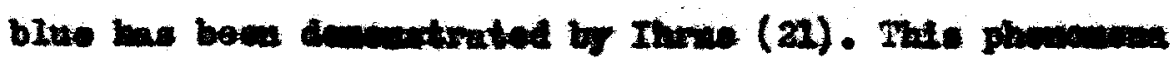

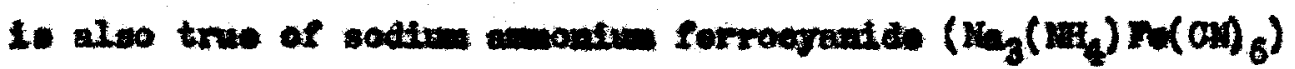

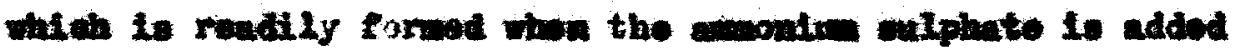

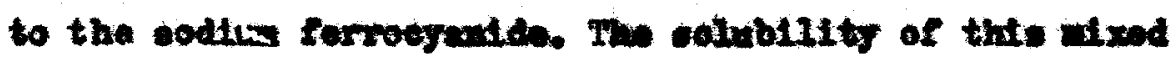

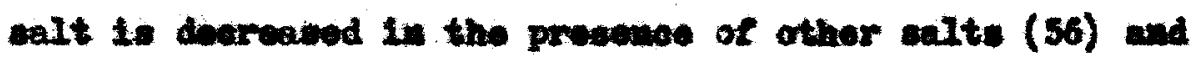

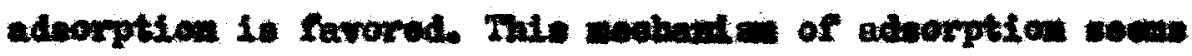

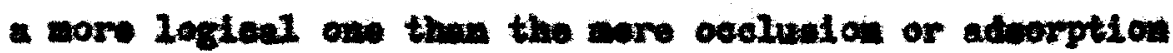
of codtue ferroogante milak is readily soluble in wator.

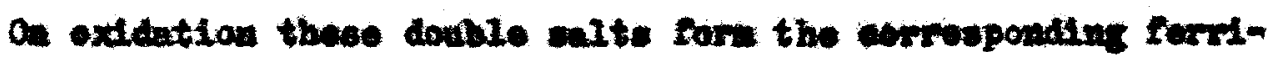

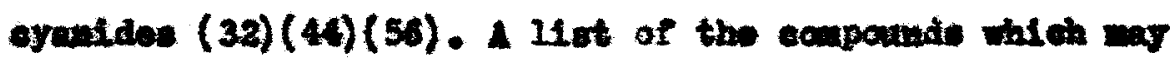
be prosent in the 11quore following axdation is shom in Table XVI.

Increased adeorption of codium formagrante $=0$ lead to 'blopding' charnoterinties in the pigant for it 1s dellqueseent and more eally wot by wator than by ofl. 


\section{TABLE XVI}

Compande Present Darlug the Formatien of Pmosinn Blne. Cemporad Coler Grratullne Strueture

\begin{tabular}{|c|c|c|}
\hline $\lim _{3} r \times(01)_{6}$ & red & dellgnewent \\
\hline$\left(m_{4}\right)_{3} n \times(O M)_{6}$ & rod & oryotanlwe \\
\hline$\left(\mathrm{mi}_{4}\right)_{2} \mathrm{Iaro}(\mathrm{ax})_{6}$ & red & eryotallins \\
\hline $\mathrm{Fe}_{2}\left(80_{4}\right)_{3}$ & $\tan$ & dellquenecut \\
\hline $\mathrm{N}(\mathrm{OH})\left(\mathrm{SO}_{4}\right)_{2}$ & browe & amorghone \\
\hline $\mathrm{No}(\mathrm{OH})_{3}$ & red-brew & anorphoas \\
\hline
\end{tabular}


2ho aborption of acmpound wh are rod would lead to a Aleoloration in the pigment wateh world be primanty

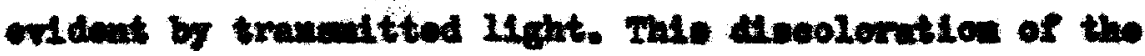

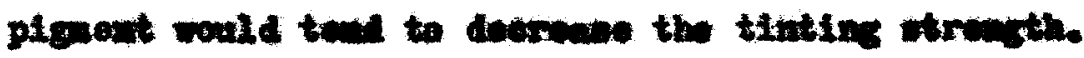

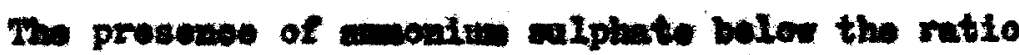

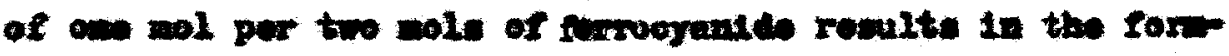

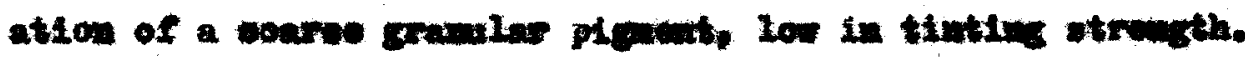

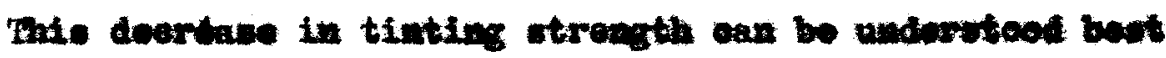

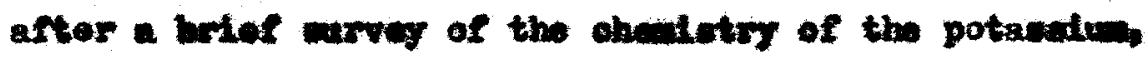

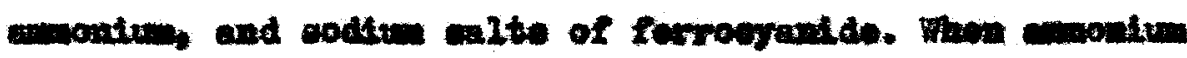

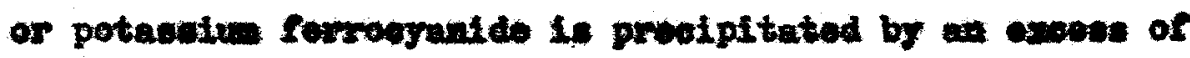

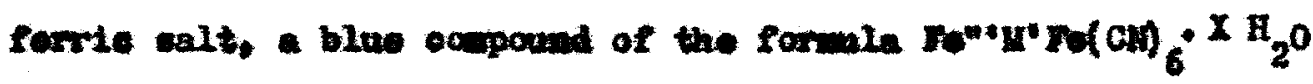

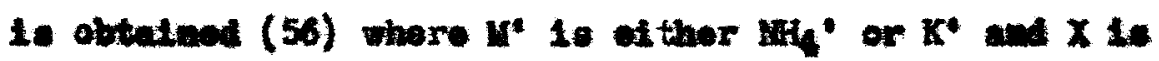

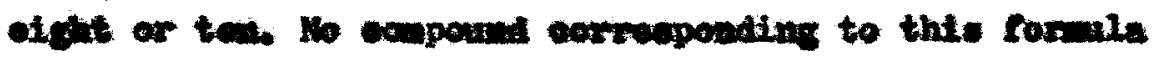

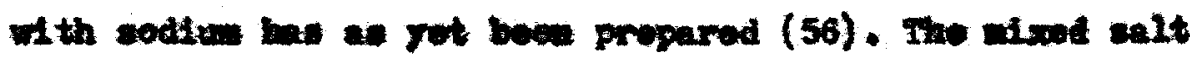

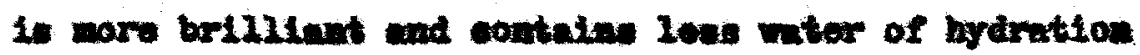

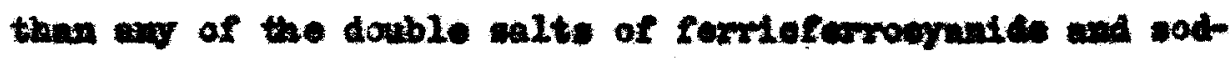

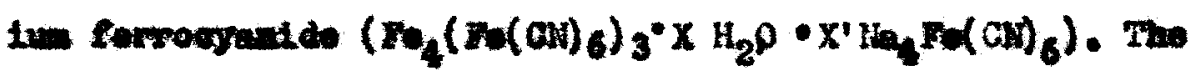

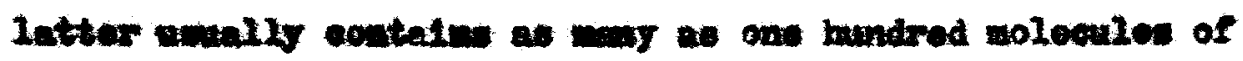
vater of hydration (56). Added water as woll as the form-

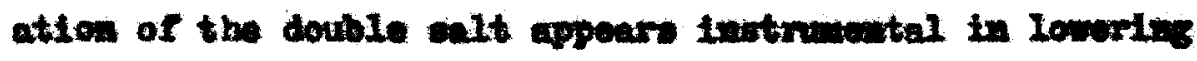

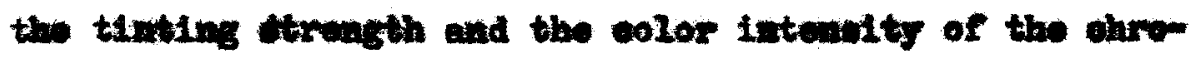


nophorle grouge in the nolpmite.

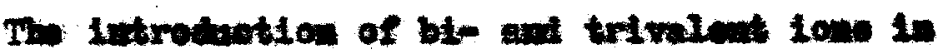

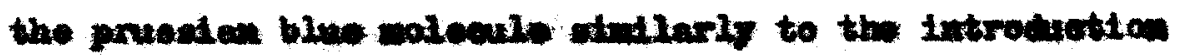

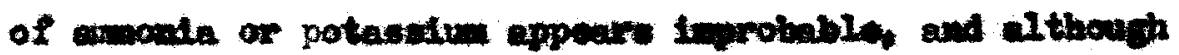
wref galte ath b4- and triwalut lone are roported (56).

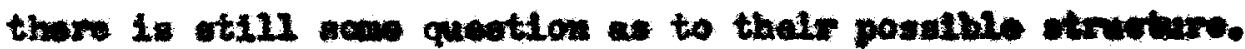

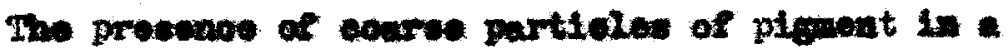

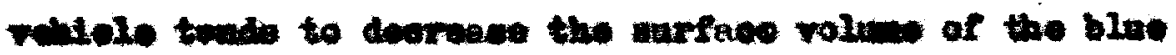

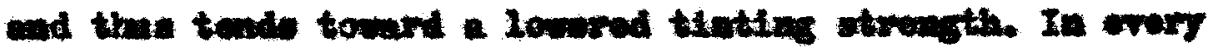
wae nere the dtepontion of the phement is all is poor

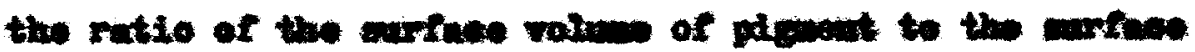

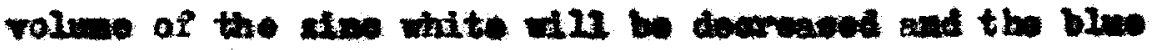

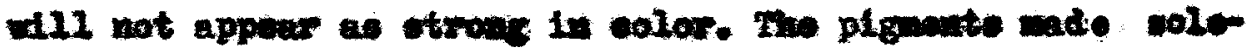

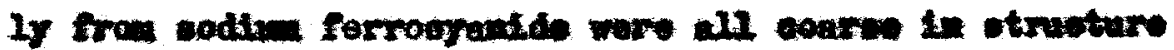
and at enpte at dippornion remitod in falriy large granlar

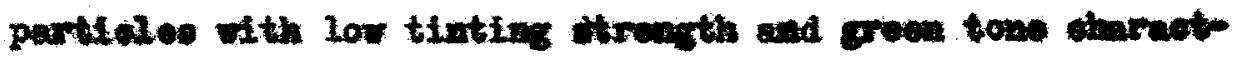

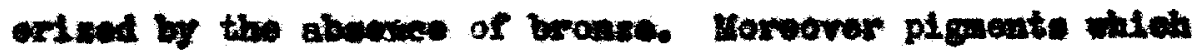

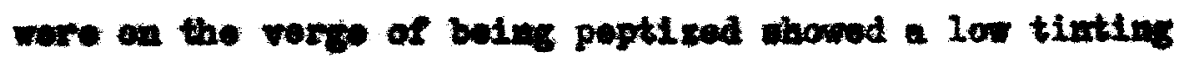

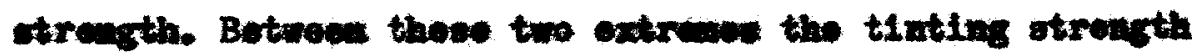

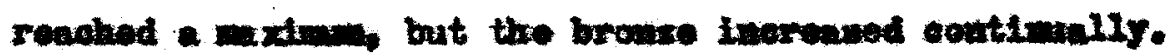


$\rightarrow$

औ

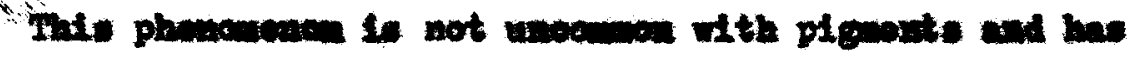

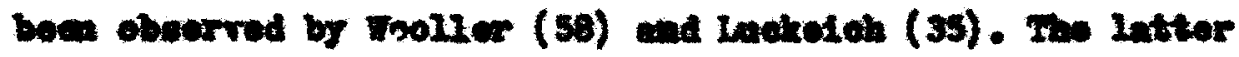

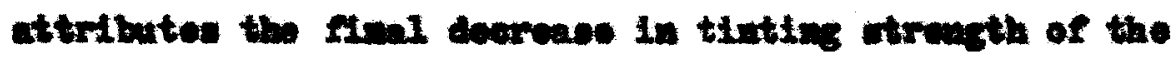

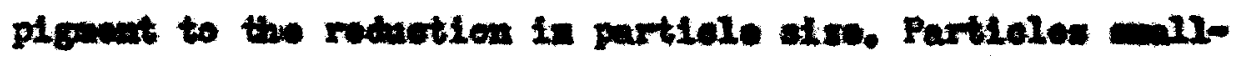
or In alte than tho vareleagth of 11 ght require a groater depth to aboort the required anount of light fres the inaldent been before the sementlon of color is produced. 
onerarar 


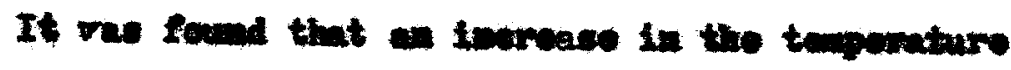

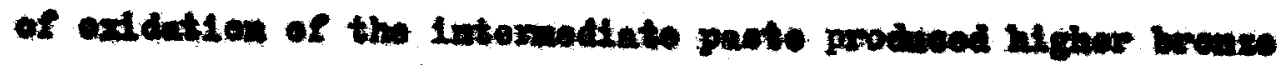
In the pigonde. In optinen tuparature for a mombrome blus was round at $250-30^{\circ} \mathrm{C}$.

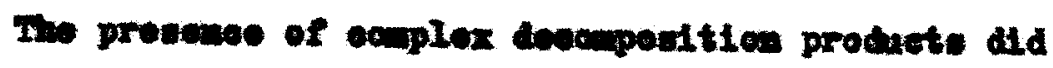

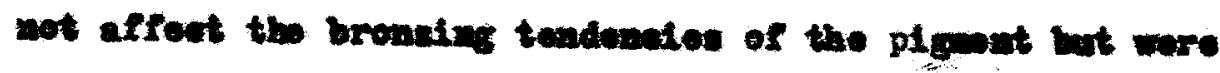

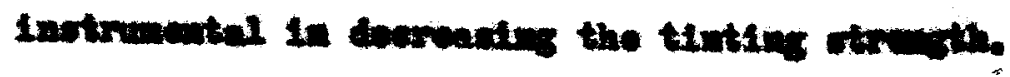

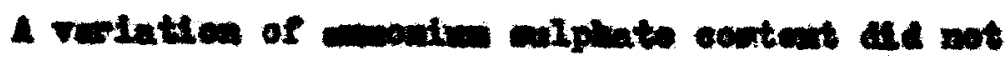

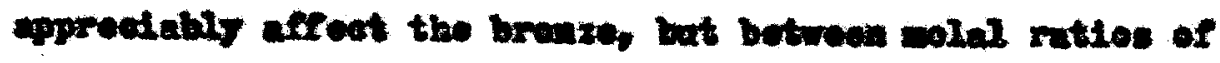

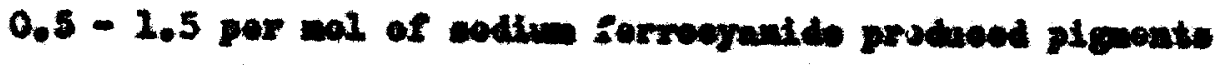
Mel in tinting itrongth and intouatty.

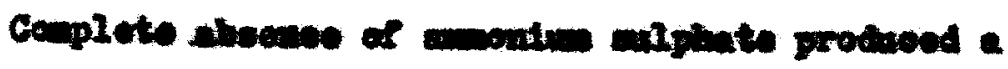
grumalar blue ploment, greon in top-tom, low in tinting strength and bellilanes, and proforentielly wot by wortor.

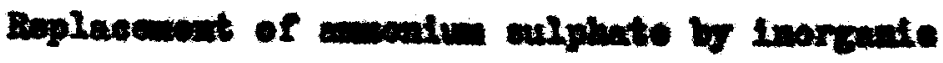
calts romultod in a loworod tintive atrongth and brillianoy.

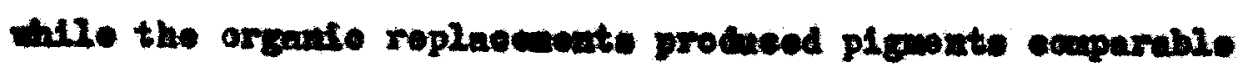

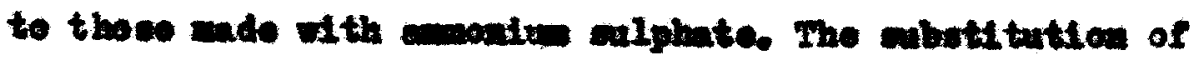

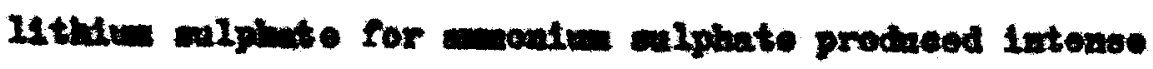

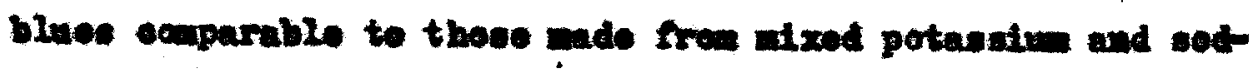

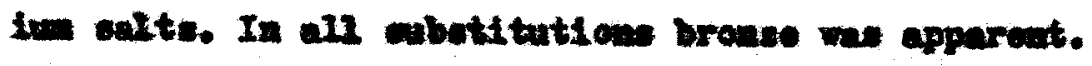




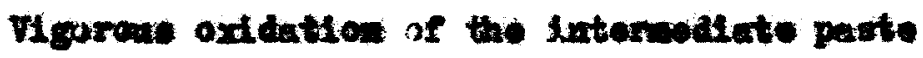
produed wronsy piencute and roduced partiele wes. The vigorout oxdation we obtainod by:

1. weo of atrome oxtalieing agoute,

2. uso of oxwow of oxtditint and,

3. raptd addition of the oxtiant.

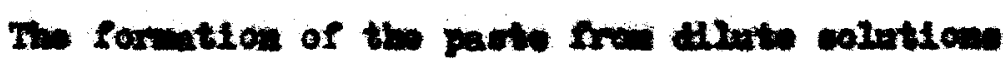

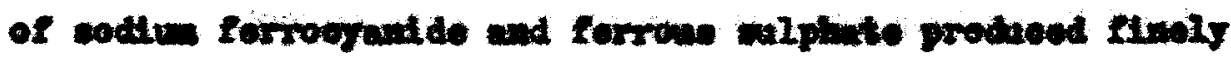
Aridied brows plemanto.

This aedition of the forrogpaid do to the forrow

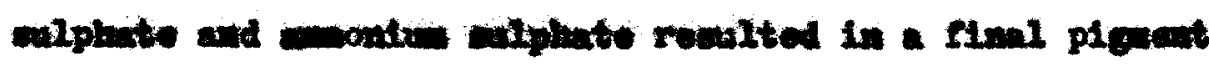

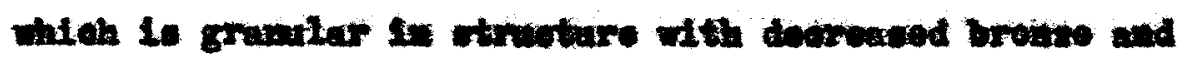
biting stranth

The formattion of the parte and its abvequent os 1dation at 20 pil velues probued the groinod brons bluen.

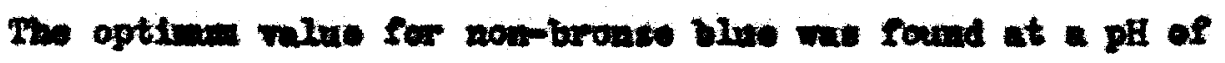
3. 50.

The prowende of soditu oreatid and sodiun forri-

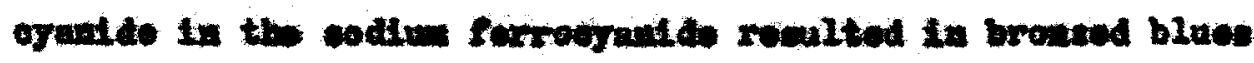
wilen wore partially paptizeot.

I-ros inventigation falled to show wor difformene

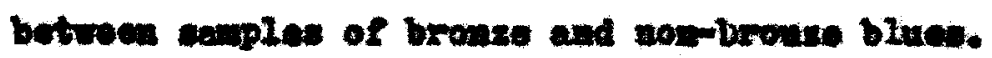


Blwe plgnents ade from the of or $\beta$ complgaration of codive forrograntide singly shomed wo approetable Alf In wronse.

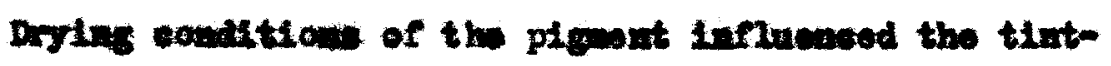

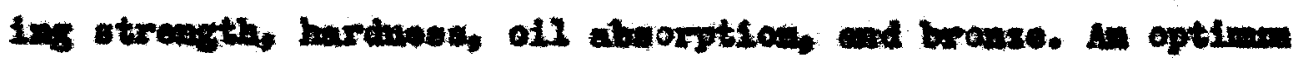

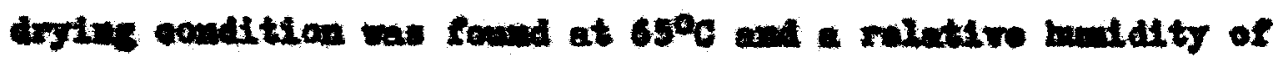
so parcout.

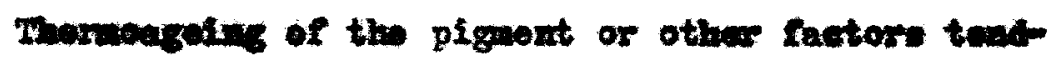
ing to produce peptisation romited in brondy bluos.

a Les rofreetive indox of the velule prenoted wroufing toudematee of a plgront.

The adelition of bleak pignente to the blue tonde to deoweave the intansity of moniented light and tonde to dearwase Ifable broses.

Bromes wall found to be a rolume obrateristio

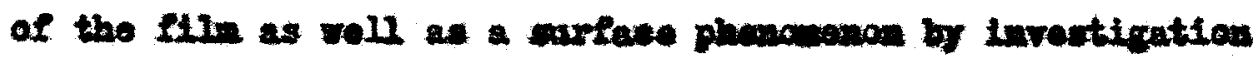
of logquer filme. 
comoustons 


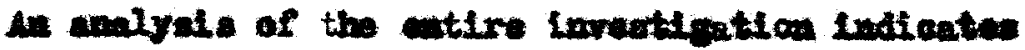

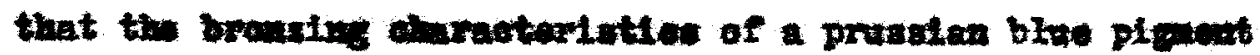

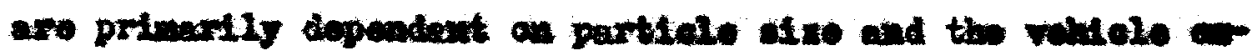

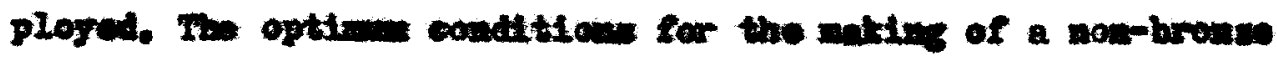
praseien blu pignent Lwolves the production of a partiele

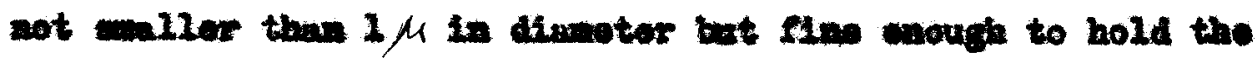
tinting otrongth.

Nor the comalation of the plgmente Inventigated ix this thools, optime condition for the alinimation of Wrowat wares

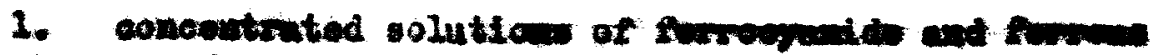
alplate. the former botes adtad to the lattar.

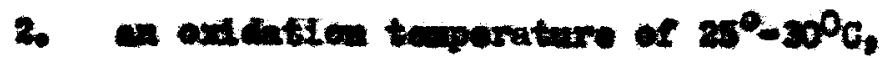

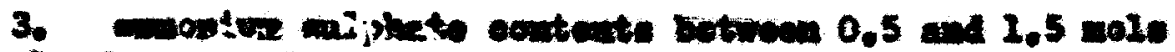
per bol of collu forroctunter.

4. at or s.5.

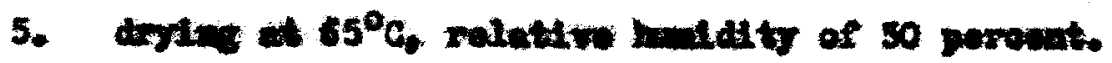


e1

BIELIOERAPH 
1. Lam, nuxw-2ts, 31,218-20,276-9, (1925).

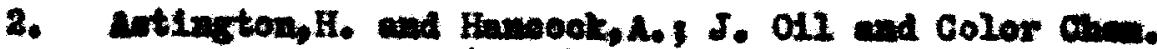
196. $\mathrm{z}_{0}$ 14,272-61 (1931).

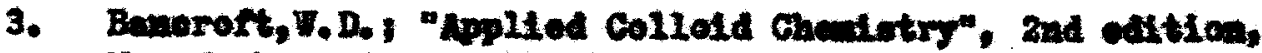
New York, Veckum-H1L, 1926.

4. Buntanury,4,K, J. Ind, Ohen, Soe, 12,143-51 (2935).

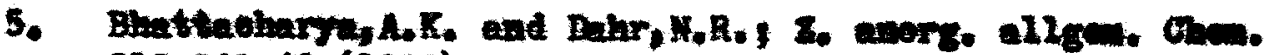
$213,240-18$ (1933).

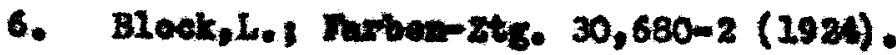

7. Ban, Helv. Ones. Acte. $22,121-53$ (1929).

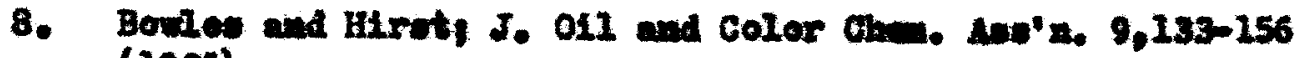
(1928).

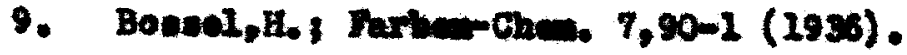

10. BrLege,O.H.C., Trane. Chen. 900. 99,1019-35.

11. Bacoh ant Soxwmens Brit. Patent 317, 274 (1989).

12. Bung, Kollold-8. 44, 156-62 (1928).

13. Forr, Muburatc, $34,1430-1,1929$.

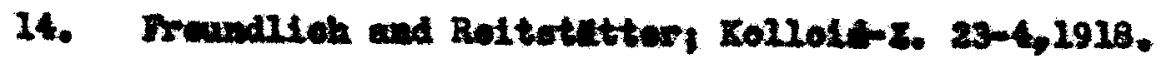

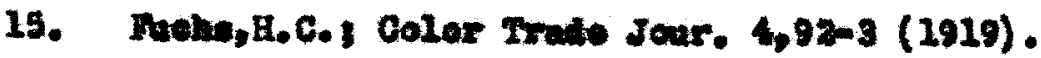

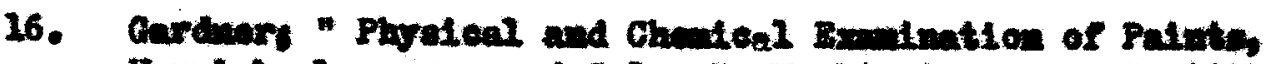

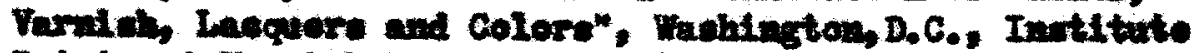

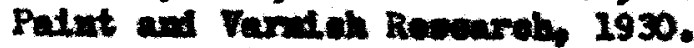

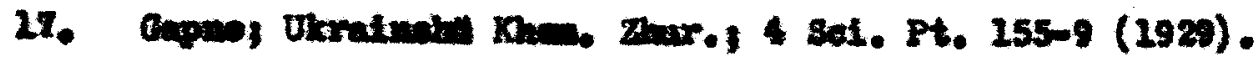

19. Growe, S.F., Druge, OLI and Palmte, 34,399 (1919).

19. Heffer. L, W., U.S. Pateut 1,600,228.

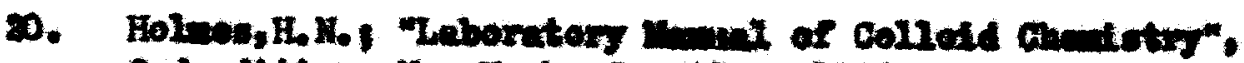

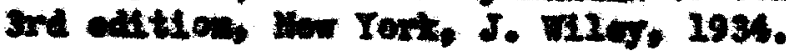




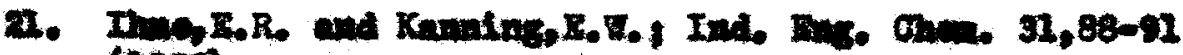
(2039).

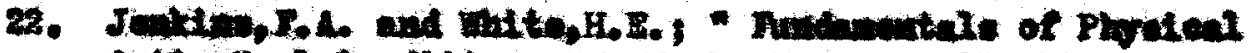

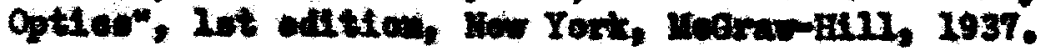

23. Jooht and singh J. Ind. Gum, sow, 14,254-9 (1937).

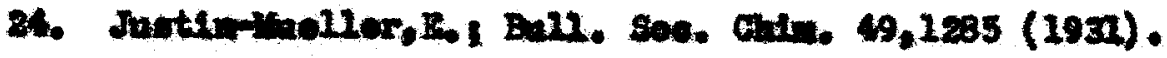

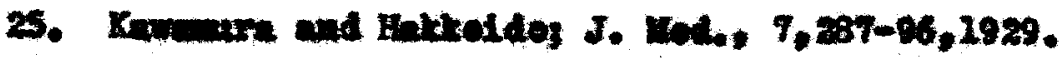

26. Kogetn and ules, Sture 137,577-8 (2038).

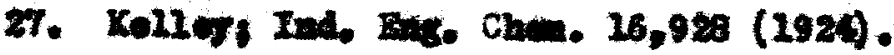

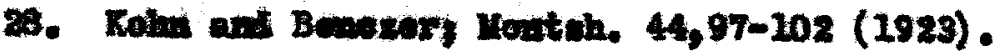

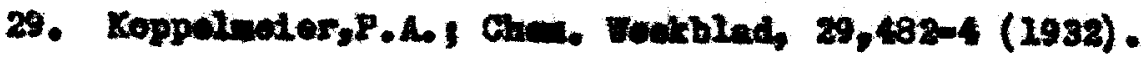

30. xapt 4m, 42,211 (1872).

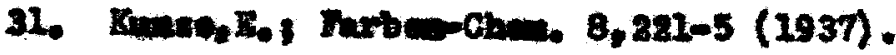

32. Lavent, J. aber F. und Ver. T. 291, (2849).

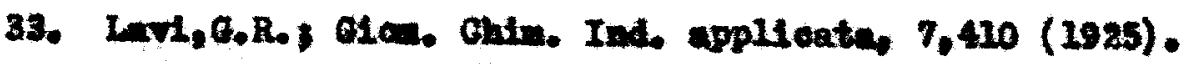

34. Locke and Edrarde, A. Gaw. J. 21, 183,413.

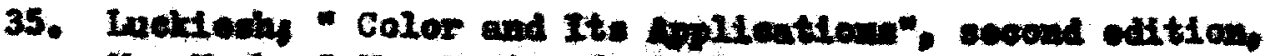
No Torit, D. The Nootrand, 192.

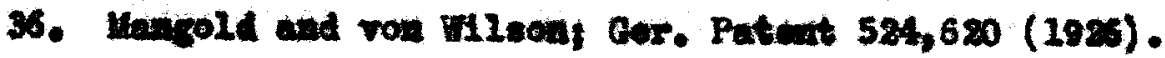

37. Uarand, Kollok4-z. 39,319-22 (1926).

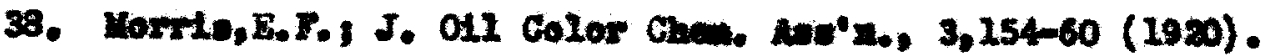

39. Moller, L, Gum. Ztg, 42,457 (1918).

40. Maller, I.V., J. Prat, Gum, 104, 241-58 (1922). 


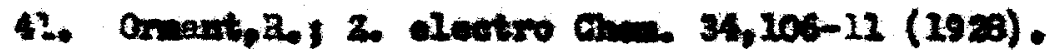

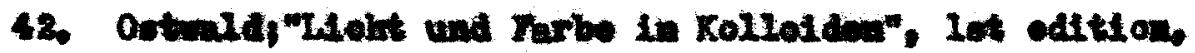
Barlin, sentinger, 1924 .

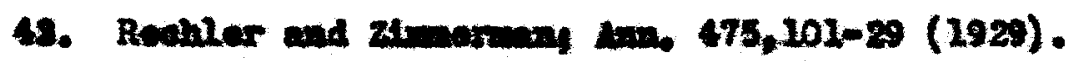

4. Radula, J. Pr. Anem. 102,43 .

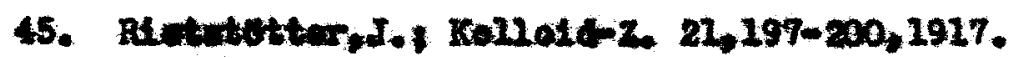

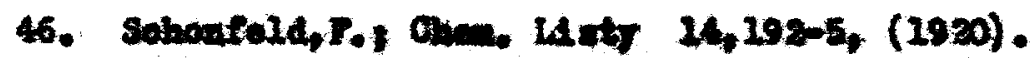

47. Sted, H, Farben-24t; 42,126,1937.

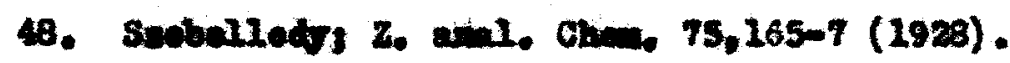

49. Tarnd, H, Caxe, Galm. IteI, 55,951-75 (1925).

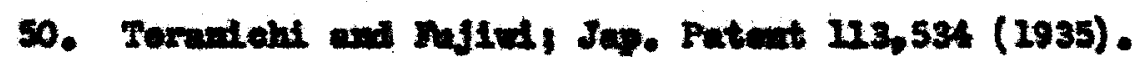

51. ragat,P.1 Rov. Prod. Guld. 24,397-104 (1921).

52. Whrt, C.8, Color Trade Jear, 2,18-32 (1921).

53. Walr, A.B., J. Ghen. 806, 127,2845-8 (1925).

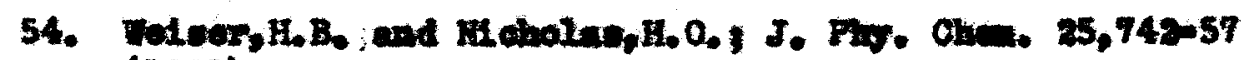
(1921).

55. Dovaleky to Pr. Ohm. 69,276 (2856).

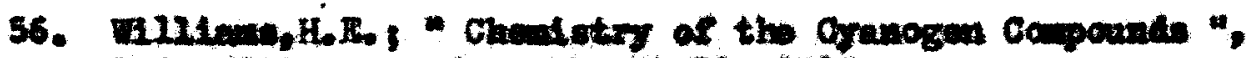
It edtion, Londoa, Omarohill. 1925.

57. HII, s., zo anorg. Onim, 4,298-99.

58. Wooller, A, Palnt Hamfacture $5,323-31$ (1935).

59. zero, 0.1 Darwe Lact. 1933,533-4.

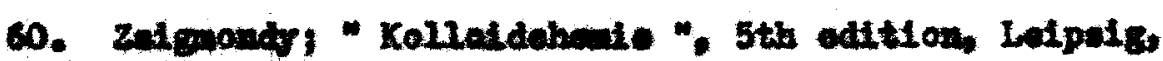
Springor, 2928. 
8.

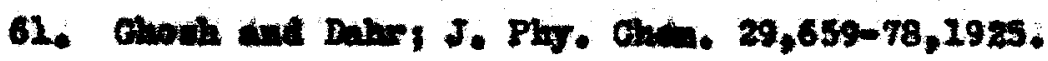

62. Choch and Dalr, Kolloter. 43, 398-95, 1927. 